\title{
The Direct Observation of Alkali Vapor Species in Biomass Combustion and Casification
}

\author{
R.J. French \\ D.C. Dayton \\ T.A. Milne
}

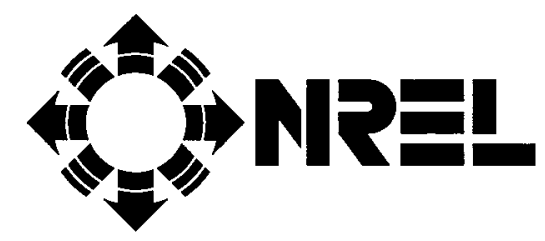

National Renewable Energy Laboratory 1617 Cole Boulevard

Golden, Colorado 80401-3393

Operated by Midwest Research Institute for the U.S. Department of Energy

Under Contract No. DE-AC02-83CH10093 


\section{The Direct Observation of Alkali Vapor Species in Biomass Combustion and Gasification}

R.J. French

D.C. Dayton

T.A. Milne

National Renewable Energy Laboratory 1617 Cole Boulevard Golden, Colorado 80401-3393

A national laboratory of the the U.S. Department of Energy Operated by the Midwest Research Institute for the U.S. Department of Energy

Under Contract No. DE-AC02-83CH10093

Prepared under Task Number BF313432

January 1994 


\section{NOTICE}

NOTICE: This report was prepared as an account of work sponsored by an agency of the United States government. Neither the United States government nor any agency thereof, nor any of their employees, makes any warranty, express or implied, or assumes any legal liability or responsibility for the accuracy, completeness, or usefulness of any information, apparatus, product, or process disclosed, or represents that its use would not infringe privately owned rights. Reference herein to any specific commercial product, process, or service by trade name, trademark, manufacturer, or otherwise does not necessarily constitute or imply its endorsement, recommendation, or favoring by the United States government or any agency thereof. The views and opinions of authors expressed herein do not necessarily state or reflect those of the United States government or any agency thereof.

\section{Printed in the United States of America Available from: \\ National Technical Information Service \\ U.S. Department of Commerce \\ 5285 Port Royal Road \\ Springfield, VA 22161 \\ Price: Microfiche A01 \\ Printed Copy A05}

Codes are used for pricing all publications. The code is determined by the number of pages in the publication. Information pertaining to the pricing codes can be found in the currentissue of the following publications which are generally available in most libraries: Energy Research Abstracts (ERA); Government Reports Announcements and Index (GRA and I); Scientific and Technical Abstract Reports (STAR); and publication NTIS-PR-360 available from NTIS at the above address. 
PROCESS RESEARCH BRANCH

INDUSTRIAL TECHNOLOGIES DIVISION

MILESTONE COMPLETION REPORT

\author{
PROGRAM: $\quad$ Biomass Power Program \\ PROGRAM COORDINATOR: Richard L. Bain \\ MILESTONE TITLE: $\quad$ Report: Alkali and Chemical Transport (Includes FY93 Milestone: \\ Alkali Screening Tests. C, 6,93) \\ MILESTONE TYPE: Control, FY 93 \\ COMPLETION DATA: $\quad 5 / 93$ \\ REPORTED BY: $\quad$ Richard J. French, Thomas A. Milne, and \\ David C. Dayton \\ PROJECT: $\quad$ Hot-Gas Cleanup Studies
}




\section{Preface}

This report was prepared by Richard French, David Dayton, and Thomas Milne of the Process Research Branch of the Industrial Technologies Division of the National Renewable Energy Laboratory. Work has been sponsored by the Biomass Power Program under NREL task no. BP313432. 


\section{Executive Summary}

This report summarizes new data from screening various feedstocks for alkali vapor release under combustion conditions. How we successfully developed a laboratory flow reactor and molecular beam, mass spectrometer interface is detailed. Its application to several herbaceous and woody feedstocks, as well as a fast-pyrolysis oil, under 800 and $1100^{\circ} \mathrm{C}$ batch combustion, is documented. Chlorine seems to play a large role in the facile mobilization of potassium.

Included in the report is a discussion of relevant literature on the alkali problem in combustors and turbines.

Highlighted are the phenomena identified in studies on coal and methods that have been applied to alkali speciation. The nature of binding of alkali in coal versus biomass is discussed, together with the implications for the ease of release.

Herbaceous species and many agricultural residues appear to pose significant problems in release of alkali species to the vapor at typical combustor temperatures. These problems could be especially acute in direct combustion fired turbines, but may be ameliorated in integrated gasification combined cycles. 


\section{Table of Contents}

Executive Summary $\ldots \ldots \ldots \ldots \ldots \ldots \ldots \ldots \ldots \ldots \ldots \ldots \ldots \ldots$ iv

Part 1. Literature Relevant to Alkali Species Release and Hot Gas Cleanup

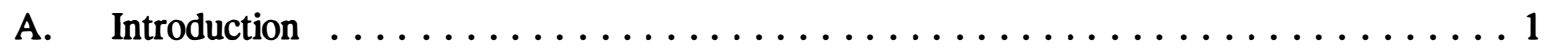
B. Gasifier/Turbine Systems $\ldots \ldots \ldots \ldots \ldots \ldots \ldots \ldots \ldots \ldots \ldots \ldots \ldots \ldots$
C. Relevant Studies of the Nature and Fate of Alkalies in Coal . . . . . . . . . 3
D. Biomass Feedstock Composition Ranges and the Nature of Binding of Alkalies . . . 17
E. Coal/Biomass Differences and Their Implications for Alkali Behavior $\ldots \ldots \ldots \ldots 23$
F. Fouling and Slagging Experience in Biofuel-Fired Boilers and Turbines $\ldots \ldots \ldots 25$
G. Past Attempts at Monitoring Alkali Transport in Gasification and

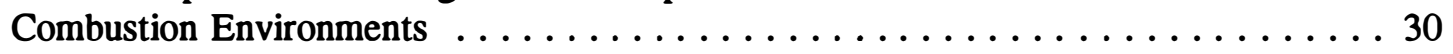

Part II. The NREL Direct Sampling System and Screening Results for Alkali Vapor Species Release During the Combustion of Herbaceous and Woody Species.

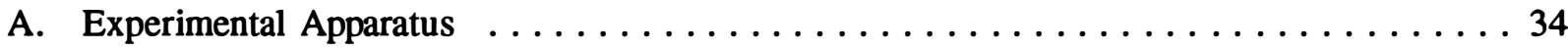

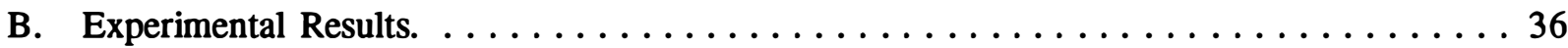

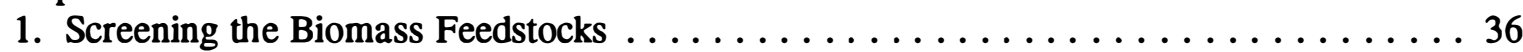

2. The Effect of Temperature on Biomass Combustion . . . . . . . . . . . . . 44

3. The Effect of Oxygen Concentration on Biomass Combustion . . . . . . . . . 49

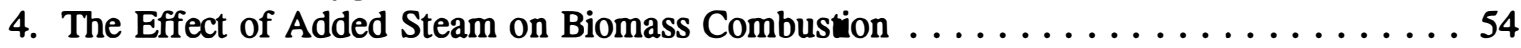

5. Comparison with Equilibrium Calculations $\ldots \ldots \ldots \ldots \ldots \ldots \ldots \ldots \ldots \ldots$

6. Quantification of Alkali Release During Biomass Combustion $\ldots \ldots \ldots \ldots \ldots \ldots$

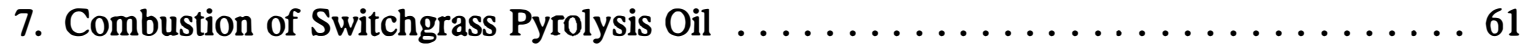

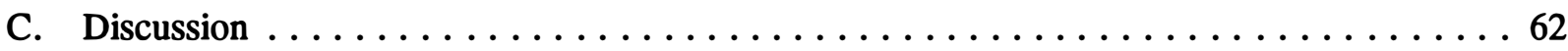

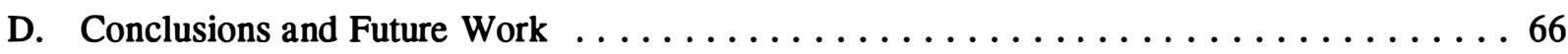

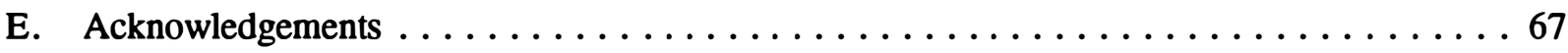

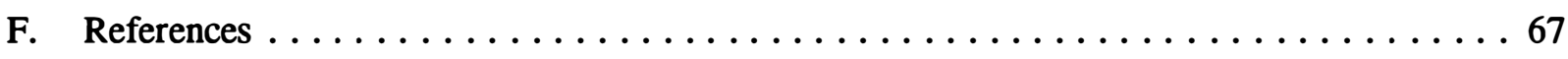

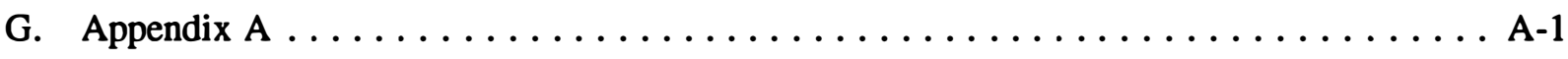




\section{Part 1}

\section{Literature Relevant to Alkali Release and Hot Gas Cleanup}

\section{A. Introduction}

In recent years interest in reducing the United States' dependence on imported oil and slowing the buildup of so-called "greenhouse gases" has fostered methods for using renewable fuels-fuels from biological products that may be grown locally and burned with no net increase in atmospheric carbon dioxide. One scenario for using such fuels is the gasification of either agricultural residues or energy crops to produce a gaseous fuel suitable for using in a combined cycle power plant employing an aero-derived turbine. Alternatively, one could pyrolize the biomass to produce high oil yields and transport, store and burn the oils in the turbine. This scheme allows for constructing many small pyrolysis plants that can be located close to the crops and minimize transportation costs to large, central turbine systems. Existing data on both coal and biomass indicate that substantial amounts of alkali compounds are emitted under some combustion and gasification conditions. These emissions may severely degrade the performance and shorten the life of the turbine, making the process economically uncompetitive. Hence there is interest in devising ways to assess and control alkali emissions so turbines may run at optimum efficiency with adequate life.

\section{B. Gasifier/Turbine Systems}

The heart of the proposed systems is a turbine similar to an aeroderivative turbine-consisting of an air compressor, a combustion chamber, and an expander section that produces the power. The output gas from the biomass gasifier (or pyrolysis oil) serves as the fuel for the combustor. These two elements make up the simple cycle. With capital investment in additional systems, the efficiency and power output from a given gas turbine can be improved. One such approach is to use the exhaust gas from the turbine to raise steam that is injected back into the turbine giving a biomass integral gasifier/steam injected gas turbine (see Figure 1.) or BIG/STIG system. In addition, an intercooler can be added to the compressor (BIG/ISTIG). The steam raised can also be used to run a steam turbine to form a combined cycle (IGCC). Various papers by Larson and Williams $(1989,1992)$ compare the economics of these various approaches.

Different types of gasifiers, such as fixed bed, fluidized bed and entrained bed, may be used to supply the fuel gas. A fluidized bed contains sand as a heat transfer agent and may be stirred mechanically as well as by the gases bubbling through it. The fluidized bed has a very uniform temperature throughout. The sand or wall material may contribute minerals, to or absorb minerals from, the biomass. In time, molten alkali compounds from the fuel may cause slagging of the sand in the gasifier. The fixed bed gasifier has no sand, but has a wide temperature variation throughout the bed. The fixed bed is fed from the top, whereas the fluid bed may be fed at any point. Gasification is conducted under substoichiometric conditions, i.e., at $0.3 \mathrm{~kg} \mathrm{O}$ per $\mathrm{kg}$ of biomass typically.

Based on existing coal and biomass gasifiers (Bain, 1991a), the process conditions may be estimated. The gases that exit the bed are a very reducing mixture, consisting mainly of $\mathrm{H}_{2}, \mathrm{CO}, \mathrm{CO}_{2}$, and $\mathrm{H}_{2} \mathrm{O}$ (Bain, 1991b) although the entering gas is 1-10 atm of air, oxygen or steam. Gas flow rates are such that the alkali species have seconds to react at high temperature under reducing conditions before reaching the turbine (Greene 1988; Peterson 1979; Lee 1990, Mojtahedi, 1990). Alkali may be in a reduced form when reaching the combustor. Temperatures in the gasifier can range from about 400 to $1100^{\circ} \mathrm{C}$ with 800 $1000^{\circ} \mathrm{C}$ being typical inside a biomass fluid bed gasifier (Bain 1991a). As the hot gas burns in the turbine 


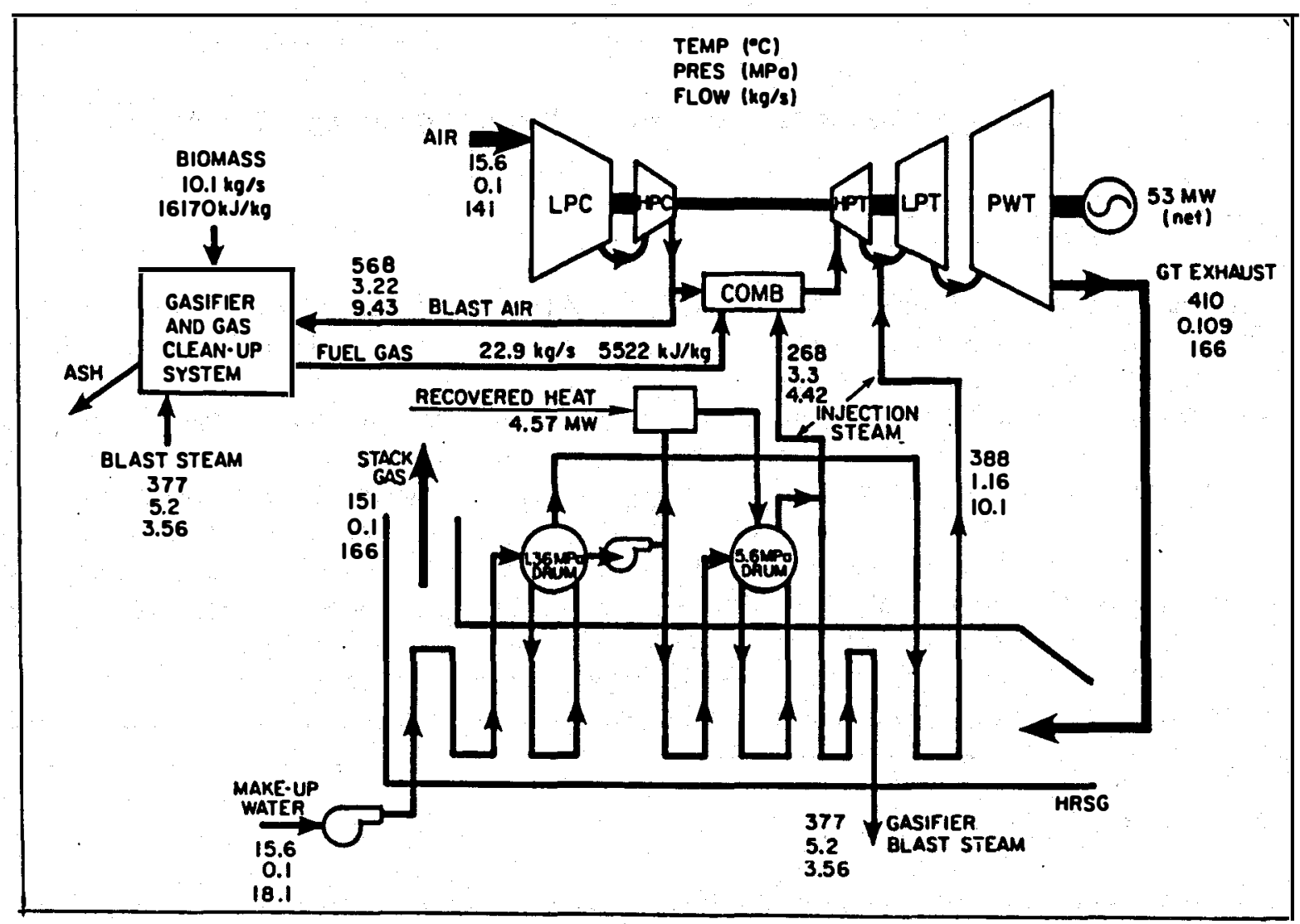

Figure 1. Biomass-gasifier steam-injected gas turbine cycle showing preliminary mass balances and related parameters for a system based on the GE LM-5000 gas turbine. The energy flow marked recovered heat accounts for feedwater preheating in the gasifier cooling jacket and in an air cooler preceding the gasifier boost compressor (not shown). Taken from Larson and Williams (1989).

hot gas burns in the turbine combustor, the temperature may rise to $1200^{\circ} \mathrm{C}$ (Larson \& Williams 1990). The added air makes the conditions oxidizing, so both gaseous and particulate forms of inorganic species will change-sulfides to sulfates, free metal to oxides, alkali carbonates to oxides, etc. As the gas expands and does work in the turbine its temperature and pressure drop dramatically. These changes will cause some species to nucleate, condense, deposit or slag in the expander.

If the alkali could be induced to form stable, sufficiently large solid particles, protecting the turbine would be a straight-forward matter. Methods for removing entrained particles, including cyclones and filters (see Bain, 1991b, for a review), would be applied to the gasifier product. Particles of about $1 \mu \mathrm{m}$ diameter or larger must be removed anyway to prevent erosion of turbine components by particle impact. However, by virtue of their tendency to form sub-micron fumes (Magasiner \& DeKock, 1987) or vapors, alkali may escape filtration and condense, coalesce, or react to form condensible species in the turbine, causing extensive damage or loss of performance.

Damage and performance loss may occur by various mechanisms. Alkali species may simply form deposits in the turbine (fouling), inhibiting air flow, reducing efficiency, and eventually stalling the turbine. Many alkali compounds are liquids at these temperatures (Stringer 1987) or may form low-melting mixtures with other materials (Misra 1992b). Their deposition on either the turbine or particles of fine ash may act to cement the fly ash to the turbine, speeding the rate of fouling and requiring more severe and expensive 
cleaning methods. These liquids may also attack the metal in a process called "hot corrosion." Particles that form may cause erosion. In addition, deposits may break loose, causing severe mechanical damage to the turbine. The rate of some processes may be increased by the blade cooling used in modern turbine designs. This speeds the rate of condensation on the blades and thermal (Soret) diffusion of small particles and droplets toward the blades. These mechanisms will be discussed further in the next section. Baxter (1993) gives an excellent review of alkali deposition processes.

Various mechanisms have been proposed to explain the corrosive effects of alkali on turbines, but turbine materials and operating conditions continue to evolve. However, a 1987 article (Stringer) gives an overview of materials in use and the understanding of hot corrosion at that date as well as some documentation of field experience. In most mechanisms a molten alkali salt damages the protective coating on the alloy-oxides of chromium, nickel, cobalt or aluminum are typical—thus exposing it to accelerated attack. Various species have been implicated in the attack: sulfates of sodium, magnesium and calcium are observed in deposits, the role of chloride in corrosion has been debated, and vanadium has been implicated in severe corrosion. Cobalt oxide and nickel oxide dissolve in liquid sodium sulfate-oxide mixtures and in sodium carbonate.

As a result of turbine failures due to corrosion and deposition, turbine manufacturers have established specifications for the content of various metals and sulfur in fuels. It will be necessary to meet these to obtain warranty from the manufacturers and present acceptable risk to potential users. Some of these specifications are listed in Table 1. It is noteworthy that the Ruston specifications require reporting of any metal present in the fuel at levels in excess of $5 \mathrm{ppm}$. Also note that the specifications are for various forms of fuel. The levels acceptable in biomass gasifier effluent will be somewhat lower because the heating value of the gas is lower than these fuels.

\section{Relevant Studies of the Nature and Fate of Alkalies in Coal}

Problems of ash behavior in coal combustion have long been of concern, particularly with the advent of large, pulverized coal power plants (eg. see Carey et al, 1954 for early discussions of tube corrosion). In fact, maximum operating steam temperatures have been essentially limited for decades by fire-side corrosion limits. More recently, the wide use of western lignites, gasification-combined cycles, and directly fired turbines using coal-water slurries have led to new studies and concerns about the behavior of mineral matter. Though coal and biomass have major differences, reference to coal studies, which are quite extensive, may be informative in terms of understanding behavior and approaches to control alkali transport in biomass systems. Recent experience in municipal solid waste mass burn systems (Bryers 1991) and with peat is also relevant, though time has not permitted incorporating of this literature in this report.

The studies with coal have been truly massive compared to work done or likely to be funded on biomass. Therefore, the approaches and techniques developed for coal need to be borrowed wherever relevant The following sections briefly summarize some of the past observations of inorganic material behavior in coals and list key references to experimental and modeling approaches.

\section{Form and Nature of Alkalies in Bituminous Coals and Lignites}

Inorganic matter occurs in coals either as micrometer-sized inclusions of minerals or salts or as cations ion-exchanged on organic functional groups such as carboxylate and phenolate. In particular, sodium is largely organic in low-rank coals, while $\mathrm{NaCl}$ and illite-like clays predominate in high-rank coals. Na plus $\mathrm{K}$ range from 200-700 ppmw in most coals. (Neville and Sarofim 1985; Wen et al, 1992; Boni 1989). Jamhankar and Wen (1981) note that added limestone or dolomite for sulfur control may be a significant source of alkali. They state that alkali in all ranks of coal ranges from $0.01-1 \mathrm{wt} \%$ with a molar average 
Table 1. Turbine Specifications for Gaseous and Liquid Fuels

\begin{tabular}{|c|c|c|c|c|}
\hline Manufacturer & $\begin{array}{l}\text { Temperature } \\
\text { (C) }\end{array}$ & $\begin{array}{c}\text { Ppm (wt.) } \\
\mathrm{Na}+\mathrm{K}\end{array}$ & $\begin{array}{c}\text { ppm } \\
\text { (wt). Ca }\end{array}$ & $\mathbf{s}$ \\
\hline United Aircraft ${ }^{1}$ & $1050-1110$ & $0.2-0.6$ & 0.1 & $0.18 \mathrm{~mole} \%$ \\
\hline Pratt \& Whitney ${ }^{1,2}$ & & 0.1 & 0.01 & $0.18 \mathrm{~mole} \% 0.25 \mathrm{H}_{2} \mathrm{~S}$ \\
\hline Westinghouse ${ }^{1}$ & 1080 & $\begin{array}{l}0.073 \\
0.15^{4}\end{array}$ & 1.4 & $0.28 \%$ (wt.) \\
\hline General Electric ${ }^{1}$ & $1050-1110$ & $0.1_{3}$ & 0.23 & 1ppm \\
\hline GE, Liquid ${ }^{5}$ & & $\begin{array}{l}0.25^{6} \\
1^{7}\end{array}$ & 2 & \\
\hline Ruston, Nat. Gas ${ }^{8}$ & & 1 (na) & & $3 \%\left(\right.$ vol, $\left.\mathrm{H}_{2} \mathrm{~S}\right)$ \\
\hline Ruston, liquid ${ }^{9}$ & & 1 & 1 & $0.3-0.5 \%(w t)$ \\
\hline \multicolumn{3}{|c|}{$\begin{array}{l}\text { 1(Scandrett, 1984) For coal derived } \\
\text { gaseous turbine fuel }\end{array}$} & \multicolumn{2}{|c|}{ 5(Todd, 1991) Liquid fuel specification. } \\
\hline \multicolumn{3}{|c|}{$\begin{array}{l}{ }^{2} \text { Aircraft derived turbine using gaseous } \\
\text { fuel. }\end{array}$} & \multicolumn{2}{|l|}{${ }^{7} \mathrm{~K}=0$} \\
\hline \multicolumn{3}{|c|}{${ }^{3}$ Based on liquid fuel specifications. } & \multicolumn{2}{|c|}{${ }^{8}$ (Ruston, 1981) For natural gas fuel. } \\
\hline${ }^{4}$ Coal derived hot $\mathrm{g}$ & & & ${ }^{9}$ (Ruston, & 980) Liquid fuels. \\
\hline
\end{tabular}

$\mathrm{K} / \mathrm{Na}=2$. Hastie et al. (1981) quote a range of organic-to-inorganic $\mathrm{Na}$ of 2 to 9 , whereas $\mathrm{K}$ ranges from 0.01 to 0.1 .

Huffman et al. (1989) note that in lignite (a young coal) $\mathrm{Na}$ is the main alkali and is believed to be bound to oxygen anions in carboxyl groups. In bituminous coals, $\mathrm{K}$ is the main alkali and is contained almost exclusively in illite clays. $\mathrm{Na}$ in bituminous coals is usually as $\mathrm{NaCl}$, sometimes in solution in pore moisture. Srinivasachar et al. (1989) note that some $\mathrm{Na}$ may occur as $\mathrm{Na}_{2} \mathrm{SO}_{4}$, as well as $\mathrm{NaCl}$ inclusions. In most low-rank coals, the $\mathrm{Na}$ is highly ion exchangeable, including some sites on clay minerals (Sondreal et al., 1985). The alkaline earths, $\mathrm{Ca}$ and $\mathrm{Mg}$, can also be atomically dispersed and play a role in ash chemistry (Quann and Sarofim, 1982, 1986).

Much of the literature refers to the acid-soluble fraction of mineral matter in coal and correlates it with slagging and fouling. Kalmanovitch et al. (1989) describe a technique for determining organic vs. mineral bound alkali. It involves a chemical fractionation involving successive leaching with $\mathrm{H}_{2} \mathrm{O}$, ammonium acetate and hydrochloric acid. Baxter (1993b) has recently adapted coal techniques to a variety of types of biomass, with revealing results.

Several groups are using a very powerful technique to characterize mineral matter in organic matrices such as coal or in deposits. The technique is computer-controlled scanning electron microscopy (CCSEM) and is available (Srinivasachar 1992) as a contract service from the University of Kentucky (Boni 1989) and the University of North Dakota (Swanson et al., 1990) among others. By this technique mineral identification by size class can be made for literally hundreds of particles in size ranges from $<2.2 \mu \mathrm{m}$ to $>46 \mu \mathrm{m}$ for a wide range of minerals (some 23 minerals were monitored for several lignites by Swanson 
et al., 1990). Hodges and Richards (1989) use ${ }^{23} \mathrm{Na}$ n.m.r. to show that $\mathrm{Na}$ is surface bound and hydrated in raw coal with no evidence of $\mathrm{NaCl}$.

A thorough summary of form and effect of elements found in U.S. coals is given by Hardesty and Pohl (1979) and is shown in Table 2. Baxter (1993a) gives a nice overview of mineral matter in coal and biomass. Figure 2 from his report shows the evolution of coals in terms of the atomic $\mathrm{H} / \mathrm{C}$ and $\mathrm{O} / \mathrm{C}$ ratios. From this diagram it would seem prudent to digest the relevant peat literature, as well as that on lignites (Van Krevelen, 1961).

\section{Alkali Release and Speciation}

The release and subsequent fate of alkali and related species that contribute to fouling, slagging, and corrosion is the heart of concern for gasification-combustion turbine applications where high temperatures are desired for high thermal conversion efficiency. It is often stated that the goal is to minimize the presence of alkali-containing species in micron and submicron size ranges that are not readily removed by cyclones. Traditionally, studies have been related to conditions of pulverized coal combustion, though recently the fossil energy program of DOE has turned its attention to hot-gas cleanup of coal gasifier effluent in IGCC systems and coal-water slurry spray combustion in direct-fired gas turbines. Both reducing and oxidizing conditions are involved (even in coal combustion, a strongly reducing atmosphere affects speciation during the volatiles and char-buming stages of combustion). Though the circumstances in biomass gasification and pyrolysis oil combustion will be significantly different than those encountered in burning or gasification of micron sized coal $(<200 \mu \mathrm{m})$, some of the same chemical processes and kinetics will apply.

A number of complex processes of vaporization, condensation, fragmentation, and agglomeration of mineral matter occur simultaneously, as inferred largely from studies of size distributions and composition of collected fly ash from well controlled combustion or single particle apparati. Several schemes that have been proposed are shown in Figures 3-6. In Figure 3, Baxter (1993) illustrates six major pathways from a single coal particle. In Figures 4 and 5, respectively, Haynes et al. (1982) and Helble and Sarofim (1989) show essentially the same steps with a graphic elaboration. Wibberley and Wall (1986) illustrate some element specific speciation and elaborate a bit on the morphology in Figure 6. Finally, in Figure 7, Wendt and Peterson (1986) relate some of the steps to different stages, temperatures and time scales in a combustion process.

It seems apparent that the processes involving biomass straw, chips, sawdust or other forms will be greatly different than for 50-220 $\mu \mathrm{m}$ coal particles. The size, morphology, heat transfer, mass transfer, time scale, temperatures, nature of surrounding minerals and their distribution will be considerably different for biomass. Thus the coal literature can be a guide to important reactions and phenomena (particularly for vaporization and subsequent fume formation and fate) but not a predictor. Following are some observations and notes about release and speciation in pulverized coal gasification and combustion, with emphasis on vapor phase release.

Baxter (1993a) points out that atomically dispersed alkali can be released by vaporization or by convective transport into evolving gases. Combustion in the high-oxygen-content, high-volatiles biomass favors forming inorganic vapors. One tends to get $<0.1 \mu \mathrm{m}$ aerosols from the inherent minerals. Hardesty and Pohl (1979) state that ". . . all of the inherent ash (non-mineral) and some of the other ash forms will evaporate. The material which evaporates is of greatest concern." The vaporization temperatures of inherent alkalies are usually surpassed within the first hundred milliseconds in PC combustion. 
Table 2. Form and Effect of Elements Found in U.S. Coals (Hardesty and Pohl, (1979)

\begin{tabular}{|c|c|c|c|c|}
\hline Element & $\begin{array}{l}\text { Range of } \\
\text { Concentration } \\
\text { in Coal, } \\
\text { ppm wt }\end{array}$ & Current Minerals in Coal & Use & Concern \\
\hline A1 & $3000-23000$ & $\begin{array}{l}\text { Kaolinite }\left(\mathrm{Al}_{4} \mathrm{Si}_{4} \mathrm{O}_{10}\right)(\mathrm{OH})_{8} \\
\text { Illite-Sericite } \\
\left(\mathrm{KAl}_{2}\left(\mathrm{AlSi}_{3} \mathrm{O}_{10}\right)(\mathrm{OH})_{2}\right.\end{array}$ & Base/Acid Ratio & Large portion of ash \\
\hline $\mathrm{Ca}$ & $50-12300$ & $\begin{array}{l}\text { Organically bound, Calcite } \\
\left(\mathrm{CaCO}_{3}\right) \\
\text { Dolomite }(\mathrm{Ca}, \mathrm{Mg})\left(\mathrm{CO}_{3}\right)_{2} \\
\text { Gypsum }\left(\mathrm{CaSO}_{4} 2 \mathrm{H}_{2} \mathrm{O}\right)\end{array}$ & $\begin{array}{l}\text { Base/Acid Ratio } \\
\text { Silica Dolomite Ratio } \\
\text { Dolomite \% }\end{array}$ & $\begin{array}{l}\text { Can reduce fouling } \\
\text { and corroding }\end{array}$ \\
\hline $\mathrm{C} 1$ & $10-260$ & $\begin{array}{l}\text { Halite }(\mathrm{NaCl}), \text { Sylvite }(\mathrm{KCl}) \\
\text { Bischofite }\left(\mathrm{MgCl}_{2} \quad 6 \mathrm{H}_{2} \mathrm{O}\right)\end{array}$ & Content & $\begin{array}{l}\text { Low temperature } \\
\text { corrosion }\end{array}$ \\
\hline $\mathbf{K}$ & $100-6500$ & $\begin{array}{l}\text { Organically bound } \\
\text { Illite-sericite } \\
\left(\mathrm{KAl}_{2}\left(\mathrm{~A} 1 \mathrm{Ai}_{3} \mathrm{O}_{10}(\mathrm{OH})_{2}\right.\right. \\
\text { Biotite }\left(\mathrm{K}(\mathrm{Mg}, \mathrm{Fe})_{3}\right. \\
\left.\left(\mathrm{A} 1 \mathrm{Si}_{3} \mathrm{O}_{10}\right) \mathrm{COH}\right) 2 \\
\text { Orthoclase }\left(\mathrm{KAlSi}_{3} \mathrm{O}_{8}\right)\end{array}$ & $\begin{array}{l}\text { Dolomite\% } \\
\text { Base/Acid Ratio } \\
\text { Dolomite \% }\end{array}$ & Fouling and corroding \\
\hline Mg & $240-3500$ & $\begin{array}{l}\text { Dolomite }(\mathrm{Ca}, \mathrm{Mg})\left(\mathrm{CO}_{3}\right)_{2} \\
\text { Ankerite }(\mathrm{Ca}, \mathrm{Fe}, \mathrm{Mg}) \mathrm{CO}_{3} \\
\text { Organically bound }\end{array}$ & $\begin{array}{l}\text { Base/Acid Ratio } \\
\text { Silica Ratio } \\
\text { Dolomitic\% }\end{array}$ & $\begin{array}{l}\text { Can reduce fouling } \\
\text { and corroding }\end{array}$ \\
\hline $\mathrm{Na}$ & $1-6000$ & $\begin{array}{l}\text { Organically bound } \\
\text { Halite }(\mathrm{NaCl}) \\
\text { Tourmaline } \\
\mathrm{Na}(\mathrm{Mg}, \mathrm{Fe})_{3} \mathrm{Al}_{6}\left(\mathrm{BO}_{3}\left(\mathrm{Si}_{6} \mathrm{O}_{18}\right)\right. \\
(\mathrm{OH})_{4}\end{array}$ & $\begin{array}{l}\text { Base/Acid Ratio } \\
\text { Dolomite \% } \\
\text { Fouling Potential }\end{array}$ & $\begin{array}{l}\text { Fouling and Corroding } \\
\text { Element }\end{array}$ \\
\hline $\mathbf{P}$ & $6-300$ & Apatite $\left(\mathrm{CaF}_{2} 3 \mathrm{Ca}_{3} \mathrm{P}_{2} \mathrm{O}_{8}\right)$ & None & Fouling \\
\hline$S$ & $300-10000$ & $\begin{array}{l}\text { Pyrite }\left(\mathrm{FeS}_{2}\right) \\
\text { Organically bound }\end{array}$ & Slagging Potential & $\begin{array}{l}\text { Slagging, fouling, } \\
\text { corroding, polluting }\end{array}$ \\
\hline Si & $5000-41000$ & $\begin{array}{l}\text { Kaolinite }\left(\mathrm{Al}_{4} \mathrm{Si}_{4} \mathrm{O}_{10}\right)(\mathrm{OH})_{8} \\
\text { mlite-Sericite } \\
\left(\mathrm{KAl}_{2}\right)\left(\mathrm{AlSi}_{3} \mathrm{O}_{10}\right)(\mathrm{OH})_{2} \\
\text { Quartz }\left(\mathrm{SiO}_{2}\right)\end{array}$ & $\begin{array}{l}\text { Base/Acid Ratio } \\
\text { Silica Ratio }\end{array}$ & Major Ash Element \\
\hline
\end{tabular}

Reducing environments during gasification promote ash vaporization. Staged combustion tends to increase the fraction of submicron aerosols (Wendt and Peterson, 1986). Wibberly and Wall (1986) note that for bituminous coal combusted at $1400^{\circ} \mathrm{C}-1600^{\circ} \mathrm{C}$, fine ash size was independent of starting coal size but the amount increased with temperature. The fume is $0.02-0.2 \mu \mathrm{m}$ in size. Such fume is enhanced by the highly reducing conditions in burning char.

Chlorine is implicated in tube metal wastage in both coal and MSW combustion. British coals contain an average of $0.25 \% \mathrm{Cl}$. A significant part is in weakly bound ions associated with organic matter, with the rest as $\mathrm{NaCl}$. Totals up to $0.8 \% \mathrm{Cl}$ have been measured. Even for $300 \mu \mathrm{m}$ particles, the $\mathrm{Cl}$ is released as $\mathrm{HCl}$ within $200 \mathrm{~ms}$ (Latham and Meadowcroft, 1991). In MSW, chlorine ranges at 0.5\% \pm 0.2 . PVC 


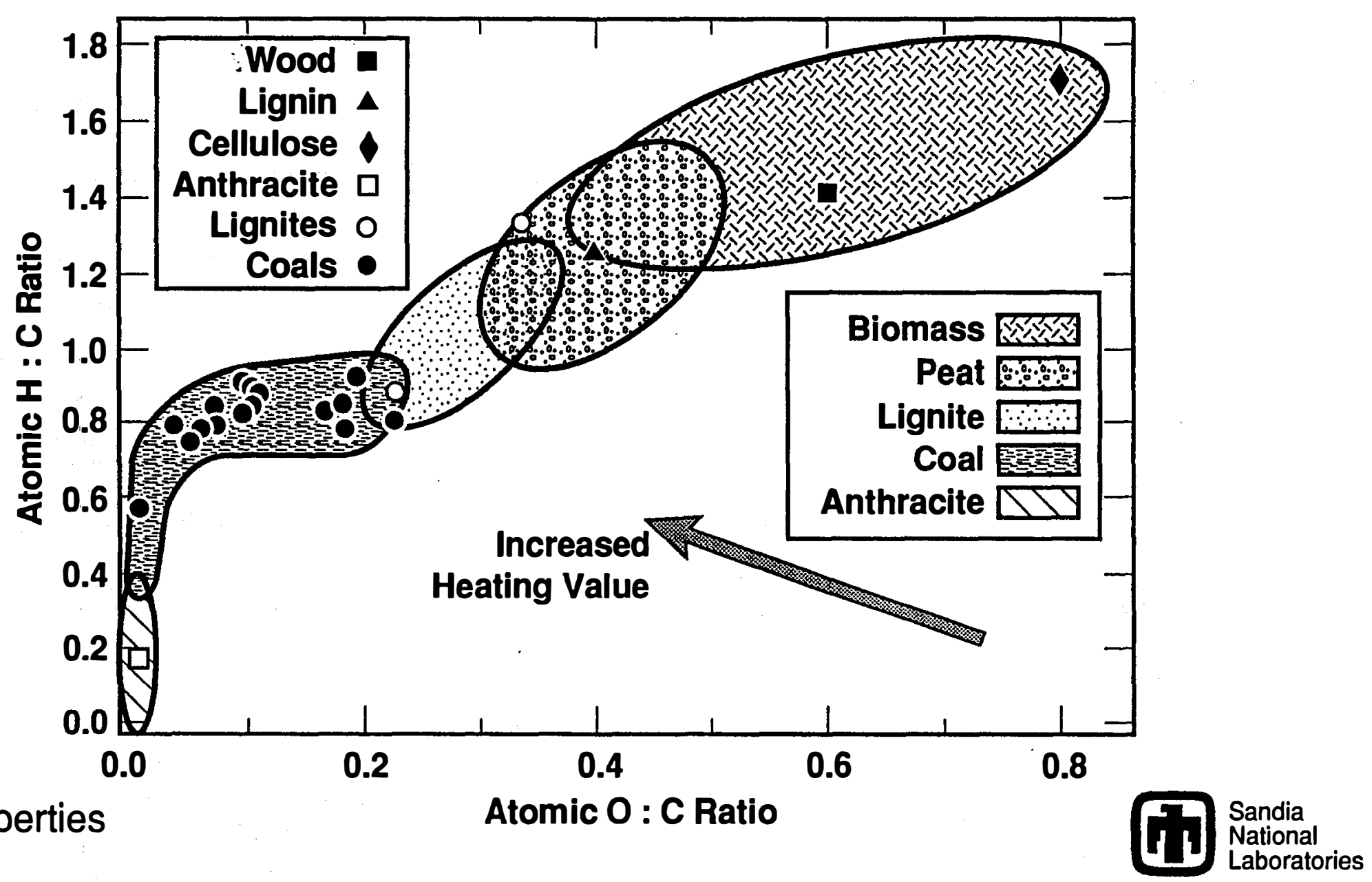

Figure 2. Coalification diagram indicating the relationship between a variety of solid fuels in terms of their chemical composition. The labeled regions represent qualitative boundaries for different fuels. The points represent quantitative results of chemical analyses for various materials.' (Baxter, 1993a) 


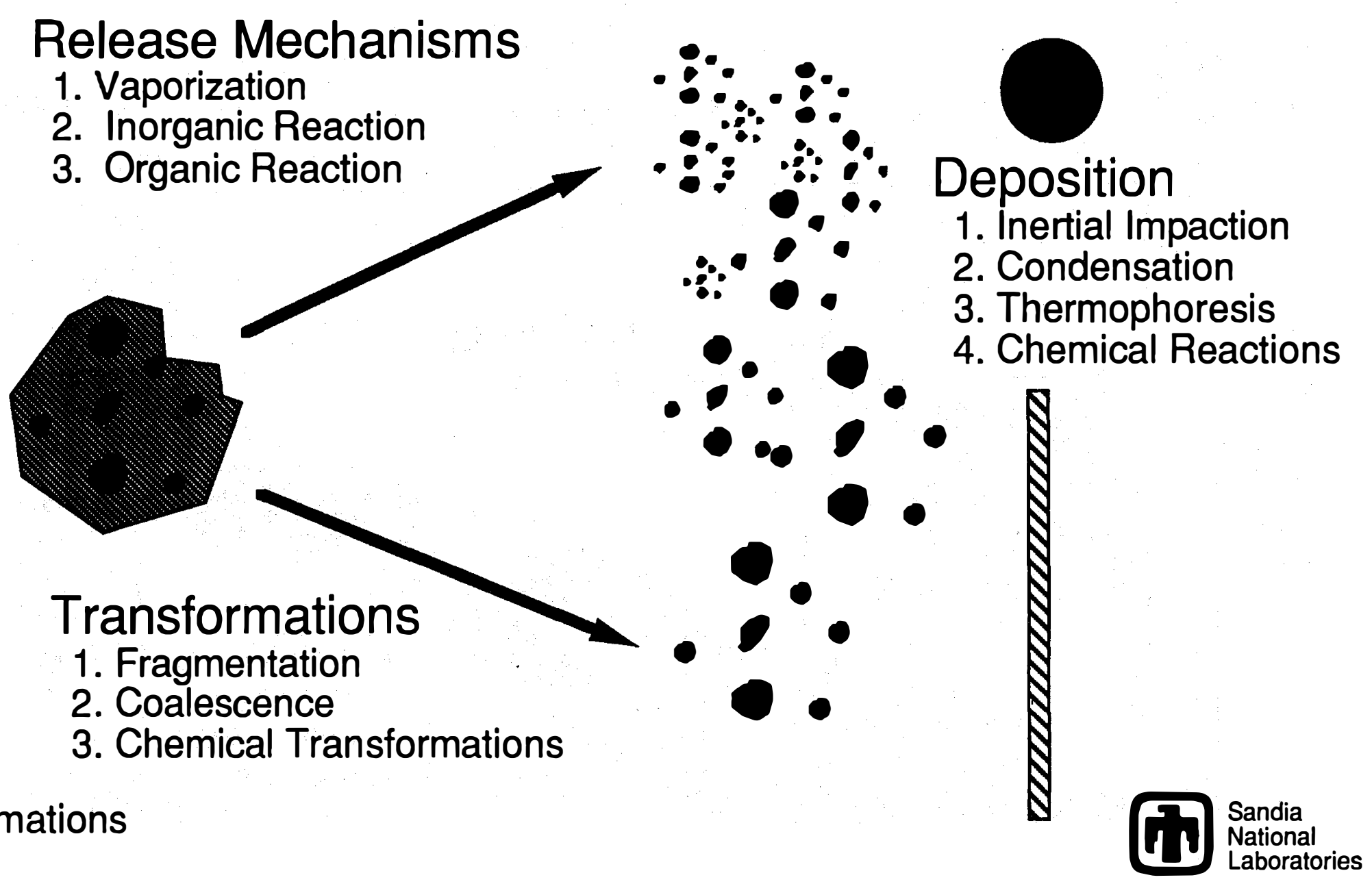

Figure 3. Schematic illustration of the fate of inorganic material in solid fuels during combustion. Inorganic material in the raw fuel may be atomically dispersed or in grains. The grains may be imbedded in the fuel. (Baxter, 1993a) 


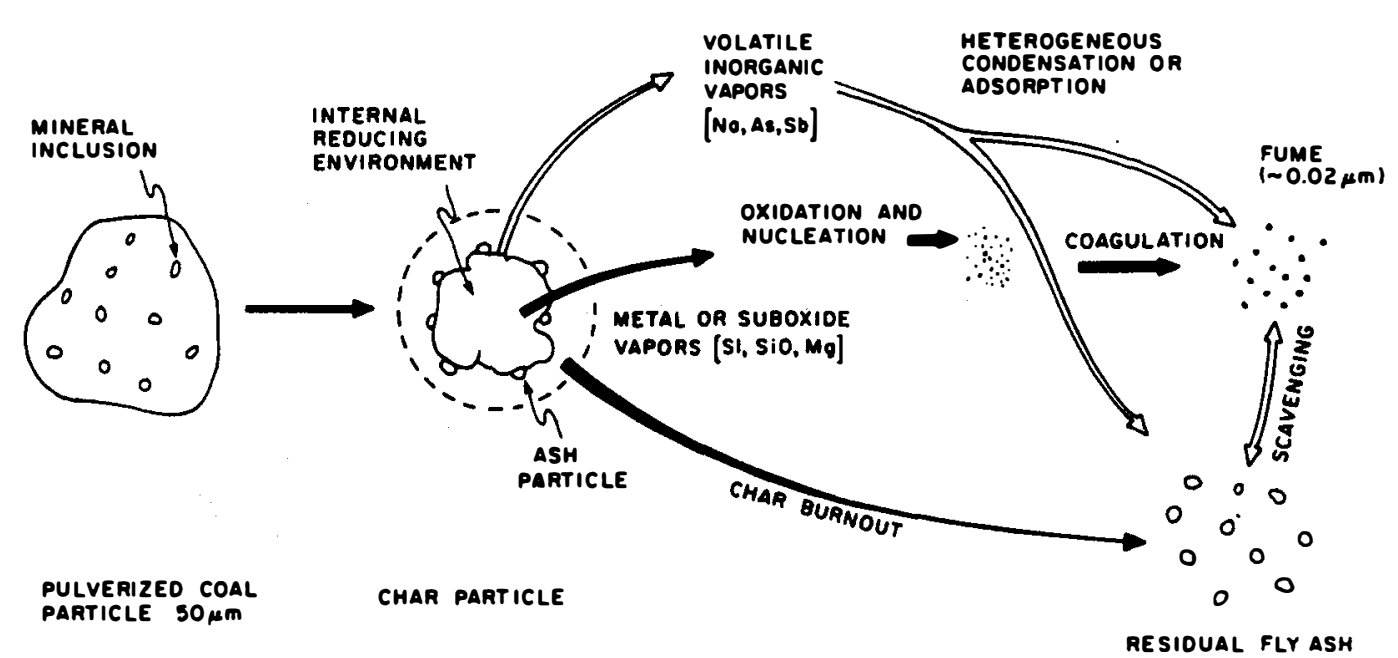

$(\sim 10 \mathrm{Mm})$

Figure 4. Schematic diagram of ash formation and behavior in coal combustion (Haynes et al. 1982)

PARTICLE SIZE IN INORGANIC AEROSOLS

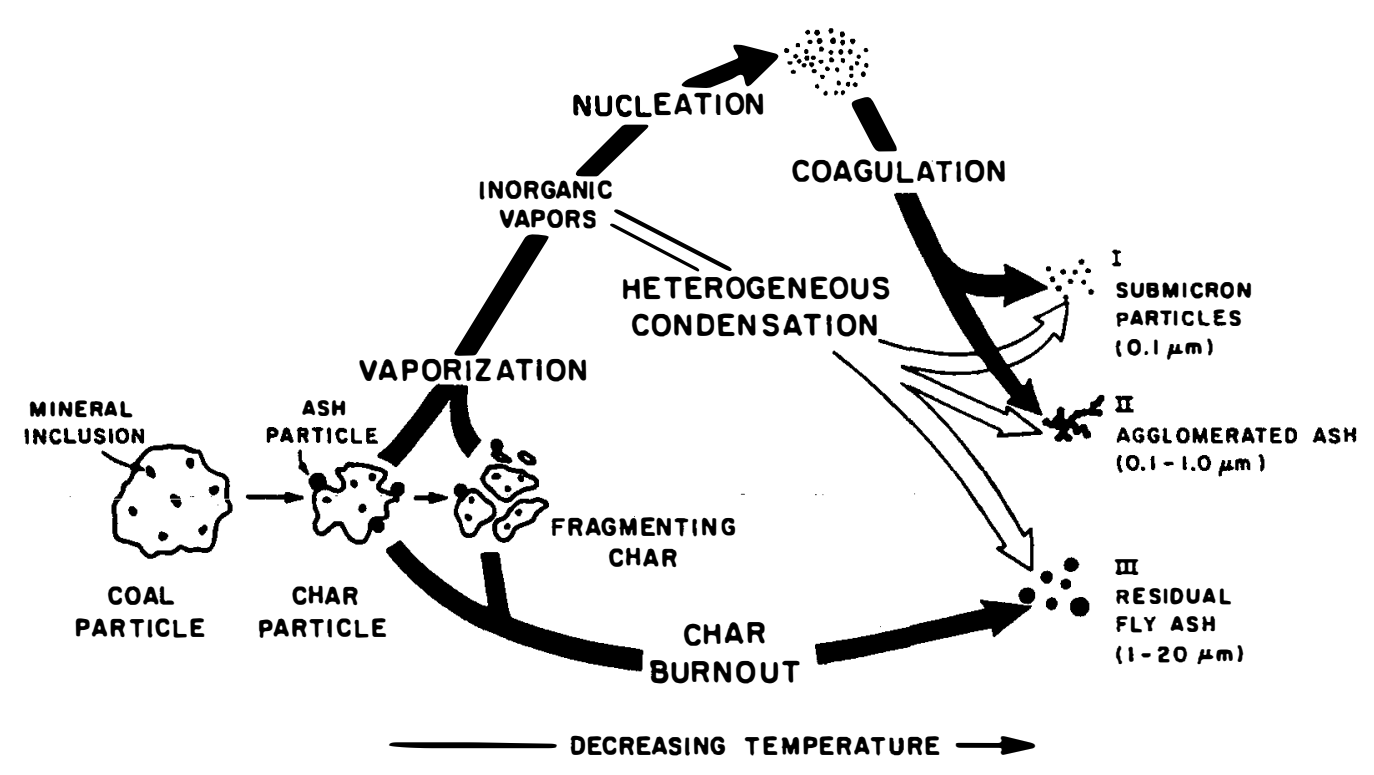

Figure 5. Schematic of ash formation processes during coal combustion (Helble and Sarofim, 1989) 


\section{Extraneous minerals}

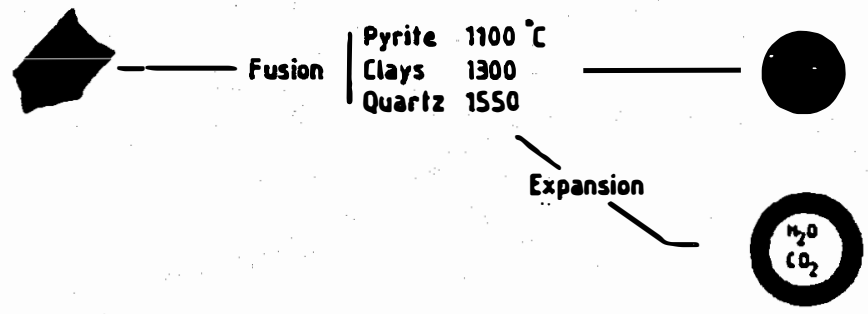

Inherent minerals

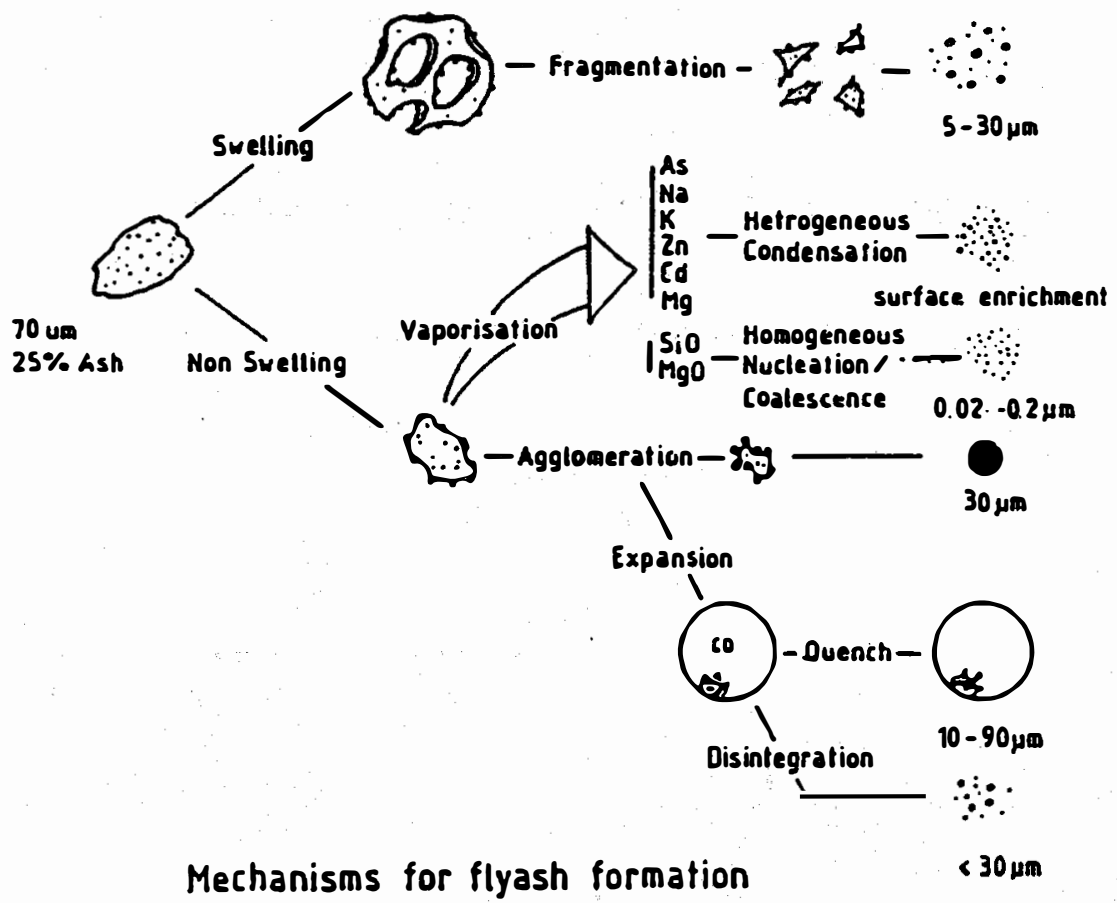

Figure 6. The process of fly ash formation (Wibberly and Wall 1986) 


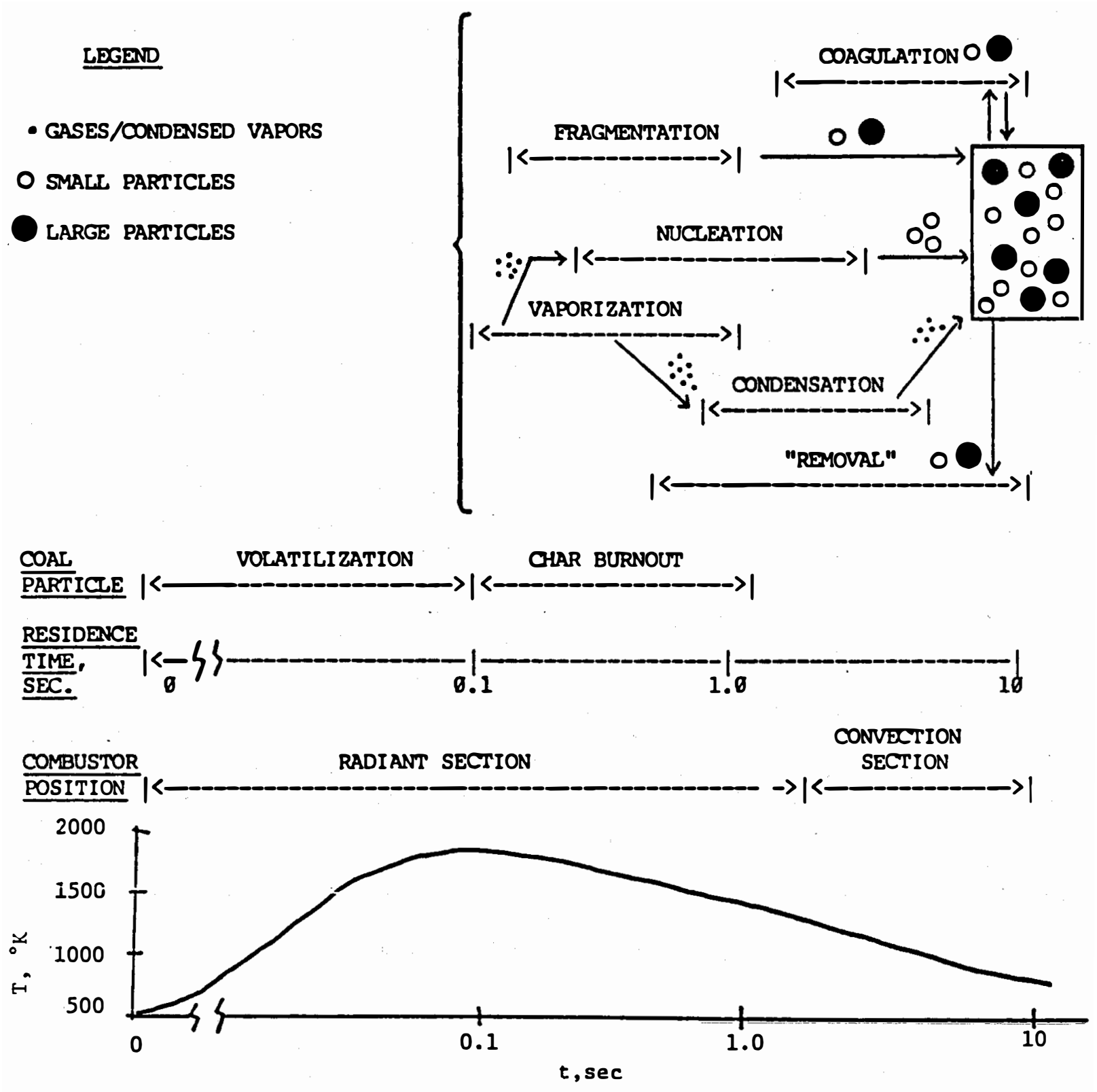

Figure 7. Time scales for combustion events (Wendt and Peterson 1986) 
is the main organic source, although the rest is mainly $\mathrm{NaCl}$ (Krause, 1991). Chlorine is a carrier for alkalis. Alkali vaporization increases with coal $\mathrm{Cl}$ content, decreases with pressure and increases as sulfur decreases. In gasification, organically-bound alkalies vaporize completely. In some cases, alkali release is inversely proportional to total ash (Jamhankar and Wen, 1981).

Thermodynamic calculations predict the formation of sodium silicate in the range of $1300^{\circ} \mathrm{K}-1850^{\circ} \mathrm{K}$ $\left(1027^{\circ}-1577^{\circ} \mathrm{C}\right)$. Below $1400^{\circ} \mathrm{K}\left(1127^{\circ} \mathrm{C}\right), \mathrm{Na}_{2} \mathrm{SO}_{4}$ is stable. At higher temperatures, the equilibrium partitioning of $\mathrm{Na}$ between sodium disilicate and gaseous alkali depends on the $\mathrm{Na} / \mathrm{Cl}$ ratio (Wibberly and Wall, 1982). Scandrett and Clift (1984) state that $\mathrm{Na}$ and $\mathrm{K}$ remain in the vapor only above $950^{\circ} \mathrm{C}$. Below this temperature, sulfates will form. In reducing environments, with sulfur as $\mathrm{H}_{2} \mathrm{~S}$ rather than $\mathrm{SO}_{2}$, alkalies will persist in the vapor right through to the combustor (equilibrium).

Flagan (1978) gives a nice description of particle and aerosol formation, with several mechanisms delineated. Benson et al. (1989) classify the transformation of mineral matter as the coalescense of mineral grains; evaporation and condensation; formation of cenospheres; and fragmentation of minerals. They state, "In order to predict the effects of inorganic constituents during coal combustion on boiler performance, the distribution of intermediate materials (ie. inorganic vapor, liquids and solids) must be known at any given point..."

In studies by Gallagher et al. (1990) of a series of coals in a 17kW downflow combustor, vaporized $\mathrm{Na}$ correlated with acid-soluble $\mathrm{Na}$, but varied inversely with silica content. Increasing temperature led to a decrease in amount of $\mathrm{Na}$ vaporized. $\mathrm{K}$ was present primarily in mineral form but correlated with $\mathrm{Na}$, suggesting $\mathrm{Na}$ can displace $\mathrm{K}$ in minerals, thus liberating it. Neville et al. (1981) studied the chemical composition of Montana lignite fume and found it to be dominated by the refractory oxides $\mathrm{MgO}$ and $\mathrm{CaO}$ $\left(\mathrm{T}>1900^{\circ} \mathrm{K}\left(1627^{\circ} \mathrm{C}\right)\right.$ ). Vaporization of $\mathrm{Ca}$ and $\mathrm{Mg}$ was attributed to a more volatile reduced state in the coal matrix. Neville and Sarofim (1985), in agreement with later results by Gallagher et al. (1990) show that above $1900^{\circ} \mathrm{K}$, release of $\mathrm{Na}$ decreases as it reacts with $\mathrm{SiO}_{2}$.

Wen et al. (1992), using a micropyrolysis cell with AA absorption to monitor alkali release, find for a Kentucky $4 \mathrm{~A}$ coal: alkali begins to volatilize at $1145^{\circ} \mathrm{C}-1204^{\circ} \mathrm{C}\left(2100^{\circ} \mathrm{F}-2200^{\circ} \mathrm{F}\right)$. In general only $50 \%$ or less of $\mathrm{Na}$ and $\mathrm{K}$ are released over the $1427^{\circ} \mathrm{C}-1538^{\circ} \mathrm{C}\left(2600^{\circ} \mathrm{F}-2800^{\circ} \mathrm{F}\right)$ range. These results represent relatively slow heatup as they were done in an electrically heated graphite furnace. Srinivasachar et al. (1989) assume that atomic alkali is the initial species, except in high-Cl coals. Sodium carboxylates are stated to dissociate at $400^{\circ} \mathrm{C}-800^{\circ} \mathrm{C}$ forming $\mathrm{Na}_{2} \mathrm{CO}_{3}$ that decomposes to atomic $\mathrm{Na}$ below $900^{\circ} \mathrm{C}$. At $1000^{\circ} \mathrm{C}-1100^{\circ} \mathrm{C}$, one expects $\mathrm{NaCl}$ to vaporize in $10 \mathrm{~ms}$, before char oxidation is fully underway. $\mathrm{NaOH}$ is the dominant compound at all times greater than $0.5 \mathrm{~ms}$. There is an unresolved question as to whether gas-phase $\mathrm{Na}_{2} \mathrm{SO}_{4}$ plays any role. Sondreal et al. (1983) note that $\mathrm{Na}$ vaporizes as metal or ions that are rapidly converted to $\mathrm{NaOH}$ that condenses on particles. Na retention in residual ash increases with $\mathrm{Si}$ and Al content. Making extensive use of CCSEM, Kalmanovitch et al. (1989) found the highest $\mathrm{Na}$ in the finest particulate fraction. Na shows its expected affinity to silicate melts.

In one of the few experiments on decomposing organically bound alkali compounds, Hastie et al. (1981) used a transpiration-mass spectrometer to study the decomposition of $\mathrm{Na}$ and $\mathrm{K}$ benzoates. At $800^{\circ} \mathrm{K}$ $\left(527^{\circ} \mathrm{C}\right)$, the benzoates decompose to carbonate and a char residue. At $1000^{\circ} \mathrm{K}\left(727^{\circ} \mathrm{C}\right)$, the $\mathrm{Na}_{2} \mathrm{CO}_{3}$ plus char reacts to give $\mathrm{Na}$ vapor and $\mathrm{CO}$. The presence of $1 \%$ halogen enhances the alkali transport by a factor of 100 at $1200^{\circ} \mathrm{K}$ but only by a factor of 4 at $2000^{\circ} \mathrm{K}\left(1727^{\circ} \mathrm{C}\right)$.

The most comprehensive study to date on transforming inorganic coal constituents in coal combustion systems is a Morgantown-funded, multi-year effort (FY87-FY90) headed by the PSI Technology Company (Boni 1989). This appears to be a model effort involving several of the country's outstanding groups and 
hence is reported here in some detail. Though it is aimed at pulverized coal combustion systems, the approach is applicable to gasification and turbine systems for biomass. The project objectives were:

- elucidation and quantification of the physical and chemical processes that occur in an environment typical of pulverized coal combustion, and that control the partitioning of coal mineral constituents among products (residual ash, aerosols, and vapors).

- chemical and physical characterization of the coal, its intrinsic, included, and extraneous mineral forms, and the spectrum of ash-related products in detail.

- developing a tractable, mechanistic model capable of predicting the observed features of the mineral matter transformation process.

The program involved eight tasks that are summarized verbatim from Boni (1989) as Table 3. Some of the observations from the 1989 progress report to Morgantown (Boni, 1989) are as follows:

Alkalies are expected as metal vapors in reducing conditions of the primary flame zone. Ash occurs bimodally, $<1 \mu \mathrm{m}$ and $10-20 \mu \mathrm{m}$. In many systems the mass of mineral matter released cannot be explained by thermodynamics. The PSI kinetic model predicts tens of milliseconds to oxidize metal vapors. The dominant alkali species in the post-flame fouling region are expected to be molecular. Some ash transformation studies employed electrodynamically levitated particles heated by a $\mathrm{CO}_{2}$ laser. The relation of the size of $\mathrm{K}$-containing mineral inclusions to $\mathrm{K}$ vaporization is under study. $\mathrm{K}$ in minerals can vaporize and subsequently condense, provided that intimate contact with carbon occurs during burnout. $\mathrm{Na}$ vapor is clearly affected by other minerals in coal.

Summary: Mineral form, size and association principally determine ash size and composition distribution. Combustion temperature and quench rate are factors in fume formation and evolution. Fragmentation of mineral inclusions lowers the ash size. Pyrite, illite and silica are key to slagging behavior. Organically bound $\mathrm{Na}, \mathrm{K}, \mathrm{Ca}$ and $\mathrm{S}$ dominate fouling. CCSEM is now a routine tool. Laser induced dissociative fluorescence is a feasible new species monitoring tool. Molecular alkali species control the post-flame environment and contribute to boiler fouling. Boni (1989) states: "A detailed understanding of the mineralogical analysis and organically bound alkali fraction, must be included in the data analysis." (The principal investigators for this work were: California Institute of Technology, Prof. Richard C. Flagan; Foster-Wheeler Development Company, Mr. Richard W. Bryers; Massachusetts Institute of Technology, Prof. Adel F. Sarofim and Janos M. Beer; University of Arizona, Prof. Thomas W. Peterson and Jost O.L. Wendt; University of Kentucky, Prof. Gerald P. Huffman and Frank E. Huggins; and PSI Technology Company, Dr. Joseph J. Helble and Srivats Srinivasachar).

Mojtahedi's et al. (1990) study on peat in a small PFBG showed a few percent sodium and potassium in the ash removed by cyclones and a few ppm in the gas-phase by AA spectroscopy of extracted gas samples and flame emission of the process gas stream. The species were not identified but were inferred, from thermodynamics, to be chlorides.

In a thermogravimetric study of $\mathrm{K}_{2} \mathrm{CO}_{3}$ and peat char (Meijer, et al., 1991), a substantial loss of $\mathrm{K}$ was observed, more in $\mathrm{H}_{2} / \mathrm{Ar}$ mixture than $\mathrm{Ar}$ alone at temperatures up to $1200^{\circ} \mathrm{K}$.

\section{Ash Deposition Mechanisms and Deposit Chemistry}

Both of these topics have been discussed and studied over many decades. Much is still speculative in view of the complex aerodynamics, sticking phenomena and complex phase chemistry of surfaces. Two major works on deposits and corrosion chemistry are Raask (1985) and Reid (1981). 
Table 3. PSI Coordinated Program on Mineral Matter transformation in Coal Combustion (Boni, 1989)

In this integrated combustion study, eight common uniform coals - Upper Freeport, Kentucky \#9, Kentucky \#11, Illinois \#6 bituminous, Eagle Butte sub-bituminous, San Miguel and Beulah lignite, and Loy Yang Brown - synthetic chars are used to provide variations in mineral type and association. Variable temperature-time-stoichiometry histories as included in several combustion devices, scales and laboratories (MIT, PSIT, and Arizona) are employed for testing hypotheses and obtaining data on ash partitioning. These include drop tube furnaces, idealized combustors and self-sustained combustion systems up to the $100,000 \mathrm{Btu} / \mathrm{h}$ level. A description of the process on a task by task basis is provided below.

\section{Task 1 Program Planning, Management, Reporting and Peer Review}

This task, performed by PSIT, consists of: (1) preparing and updating a program plan; 2) coordinating, managing, and integrating the subcontractors and project results; 3 ) preparing project reports; and 4) conducting semiannual peer review and coordination meetings of the project's principal investigators.

\section{Task 2 Coal Selection Preparation and Characterization}

This task, performed by Foster-Wheeler Development Corp. (FWDC), consists of selecting, acquiring, preparing and distributing coals that have desirable characteristics to permit an experimental determination of coal-related variables on mineral matter transformation and ash formation. These variables include coal type, coal and mineral size distribution, and mineral composition and its degree of association with the carbonaceous matrix. Mineral forms of importance included pyrites, illites, quartz, alkalis, and alkaline earths.

\section{Task 3 Advanced Techniques for Coal and Mineral Characterization}

The University of Kentucky (UK) applies advanced analytical capabilities to determine the mineral forms, mineral size, and structure of coals and selected ash samples. The samples are analyzed by computercontrolled scanning electron microscopy (CCSEM), Mōssbauer spectroscopy, X-ray diffraction, and X-ray Absorption Fine Structure (XAFS) spectroscopy.

Task 4 Fundamental Studies of Selected Ash Vaporization, Nucleation, Condensation, and Coaqulation Phenomena

Task 4, performed by CalTech, is a study of the vaporization condensation, and growth of inorganic species. Studies of ash vaporization using model ash compounds to develop a quantitative data base on ash thermochemistry are conducted in various environments, in an electrodynamic balance and in a flow reactor. Experiments designed to measure the aggregate structure of coagulating particles are also conducted under this task. Modeling these processes will include nucleation, coagulation, and condensational growth.

\section{Task 5 Fundamental Studies of Mineral Matter Vaporization and Residual Ash Formation}

Complimentary experimental modeling studies are conducted at MIT in two areas. In the first, the MIT drop-tube furnace facility is employed to study the processes that control the size distribution of residual fly ash using both selected coals and model chars. A percolative fragmentation model is employed to describe the formation of residual ash. The second subtask will determine the extent of vaporization of minerals in coals burned under simulated utility boiler conditions, and develop the test vaporization models. 
Table 3. PSI Coordinated Program on Mineral Matter transformation in Coal Combustion (Boni, 1989) (continued)

Task 6 Pulverized Coal Combustion Studies of Ash Enrichment by Volatiles and Fragmentation

The objective of this task, performed using the University of Arizona 100,000 Btu/hr pulverized coal combustion test facility, is to develop mechanistic descriptions of the size and variation of fly ash aerosol formed form the combustion of pulverized coals under conditions of varying coal type and furnace environment. Mechanisms that determine the core and surface composition are to be elucidated. The idealized, but self-sustained, flame environment of this experiment permits an assessment of particle density and shear-field influences on ash formation. A model capable of describing the general particle distribution and composition characteristics is being developed.

Task 7 Idealized Combustion Determination of Ash Particle Formation and Surface Stickiness.

In this task, PSIT employs an idealized combustion system to determine ash particle size and composition distributions for intercomparison with the dilute-phase combustion data of MIT and the selfsustained data of UA. A second phase of these experiments emphasizes the in-situ collection of ash variables and combustion environment, and employs pure minerals to determine stickiness ranges in idealized experiments. A final phase of this task implements a laser-based optical technique to determine the presence and concentration of gas-phase alkali molecular species in a drop-tube furnace combustion environment.

\section{Task 8 Model Development and Integration}

By synthesizing the models developed under tasks 4 through 6 , a mineral matter transformation model capable of predicting ash particle size and composition distributions as a function of coal and combustion system variables will be produced. The information provided by this model and the experimental data base is then reduced as an engineering mineral matter transformation model that can be used to predict the distribution and nature of the ash products.

A good, recent tutorial and mechanistic description of ash deposition is given by Baxter (1993a). He lists four processes that contribute to deposit formation and discusses each. They are:

- inertial impaction (and particle capture);

- thermophoresis;

- condensation;

- heterogeneous reaction (chemical reactions).

Properties of the resultant ash deposits that are important to combustor operation are:

- ease of removal from surfaces;

- viscosity;

- effective thermal conductivity;

- effective emissivity;

- deposit strength.

To this might be added "corrosivity" for long term operation. The deposit properties of elemental composition, morphology, porosity, and chemical species composition affect the above six properties. Baxter concludes that "mineralogy of the inorganic material, as opposed to the elemental composition of the ASTM fuel ash, determines many important deposition mechanisms and deposit properties." 
Applying his experience with coal, Baxter presents some qualitative hypotheses about a typical biomass fuel dominated by atomically dispersed inorganic material as compared with bituminous or higher rank coals:

(1) Rate of deposit accumulation will be highest initially, monotonically slowing as the ash layer builds up.

(2) Deposit tenacity will be high in all cases, with deposits contacting combustor surfaces very efficiently.

(3) Deposit strength will be high up to deposit temperatures that reach softening or melting points. In all cases, deposits will be dense.

(4) Deposits will have smooth surfaces and little porosity.

(5) Emissivity and absorbtivity will be relatively low.

In discussing corrosion and fouling in refuse (MSW) fired boilers, Plumley et at (1991) note that both may be related to "reducing atmosphere" regimes in combustion, caused by clumps of fuel. This might be germane to the bulky and anisotropic forms of biofuels vis-a-vis finely pulverized and well dispersed coal. In MSW firing, corrosion increases linearly with $\mathrm{Cl}$ concentration beyond $900^{\circ} \mathrm{F}\left(482^{\circ} \mathrm{C}\right)$ (Krauss, 1991). Hasselriis (1991), discussing his experience with combustion of municipal refuse, notes that at $1 \% \mathrm{Na}_{2} \mathrm{O}$ in ash, fouling is low, whereas at 5\% it is high. Due to slagging problems, and other difficulties, he stated that it has generally been concluded that refuse derived fuel (RDF) should be fired alone.

\section{Special Considerations for Turbine Combustors}

Scandrett and Clift (1984) note that coal gasifiers and combustors generally release 1-10 ppm of alkali, necessitating 1-2 orders of magnitude reduction in release for use in turbines. In controlled lignite slurry tests of a Beulah Zap lignite under turbine combustor operating conditions, high ash content and low ash fusion temperature led to significant ash deposition and slagging (Swanson et al., 1990).

CRS Sirrine (1990), in a report on developing of an air-blown coal gasifier/gas turbine, state that one needs to remove the $\mathrm{Na}$ before the combustion, either within the gasifier or downstream of cyclones. They favor in-bed absorbers such as kaolin-based material. They have carried out equilibrium calculations for various zones of an IGCC system: oxidation zone of the gasifier; reduction zone; gasifier exit; hot gas cleanup unit (assumed $1000^{\circ} \mathrm{F}$ here); gas turbine combustor exhaust; and gas turbine exit. They estimate only 0.25 to $0.50 \%$ of alkali will vaporize in coal, giving about $1 \mathrm{ppm}$ vapor alkali in the gasifier output.

Nelson (1987) estimated the likely contaminant ranges for Illinois \#6 coal in fixed-bed, fluid-bed, entrained-bed and pressurized fluid bed combustors. For fixed beds at $1700^{\circ} \mathrm{F}$, he projected $\mathrm{NaCl}$ at 0.8-23 ppm and $\mathrm{KCl}$ at 2-12 ppm. Ahluwalia and Im (1989) note that factors that impact slurry $\left(\mathrm{coal} / \mathrm{H}_{2} \mathrm{O}\right)$ atomization also affect fly ash size distribution and delivery to turbine blade surfaces. $\mathrm{Na}_{2} \mathrm{SO}_{4}$ induced hot corrosion is also discussed.

Moore (1986), in an overview of DOE's gas-stream contaminant control program, cites the need to "develop alkali and particle control to allow acceptable operation of conventional gas or expander turbines to use with PFBC and direct coal-fired combustors as well as gasifiers." He states that preliminary data to date indicate that at $1550^{\circ} \mathrm{F}\left(843^{\circ} \mathrm{C}\right)$ to $1600^{\circ} \mathrm{F}\left(871^{\circ} \mathrm{C}\right)$, pressurized fluid bed operating temperatures, the major percentage of the alkali is in the condensible form and alkali control may not be necessary for gas streams up to $1600^{\circ} \mathrm{F}$. 
Spacil and Luthra (1982) note that alkali condensates in pressurized fluid bed coal combustor/gas turbine combined cycle should increase with $\mathrm{Cl}$ content, even at $0.1 \% \mathrm{Cl}$. Rothrock et al. (1990), in a paper on low-cost fuels for coal-fired turbines, give a table of fuel properties for coal/water slurries, together with methods of testing (e.g. for spray droplet size distribution, viscosity, etc.) that may be useful for pyrolysis • oil fuels.

Robson and Blecher (1981), in an assessment of fuel-gas cleanup systems for turbines, note that alkali from gasifiers could be in the high ppm range. They cite evidence of a synergistic effect of $\mathrm{K}$ and $\mathrm{Na}$ combined. Williams and Bedick (1988), in a technology status report on gas stream cleanup note that for direct-fired gas turbines at $\mathrm{T}>2000^{\circ} \mathrm{F}\left(1093^{\circ} \mathrm{C}\right)$, novel cleanup systems must be developed. $\mathrm{NH}_{3}$ needs to be separated prior to burning for IGCC. They cite the MRI work using MBMS (Greene, 1988) showing early release of $\mathrm{Na}(\mathrm{g})$ followed by a fume (presumably). They noted that SRI (Krishnan 1992) was starting MBMS work to identify alkali sulfate gaseous intermediates.

Wen et al. (1992) discuss alkali retention in a slagging combustor turbine. Hot gas enters the turbine at $1010^{\circ} \mathrm{C}\left(1850^{\circ} \mathrm{F}\right)$.

In the context of gas-turbine combined cycles, Sondreal et al. (1985) give summary tables of available alkali loss data for several gasifiers (Table 4). METC measured $0.9 \mathrm{ppm} \mathrm{Na}$ and $3 \mathrm{ppm} \mathrm{K}$ from a dry-ash, fixed gasifier operating on North Dakota lignite. In wet combustion, $0.1 \mathrm{ppm} \mathrm{Na}$ and $0.4 \mathrm{ppm} \mathrm{K}$ were seen. Other fixed-bed gasifiers show $\sim 10 \mathrm{ppm} \mathrm{Na}$. The KRW fluid-bed gasifier output contained $45 \mathrm{ppm}$ $\mathrm{Na}$ and $1.5 \mathrm{ppm} \mathrm{K}$ at $900^{\circ} \mathrm{C}$.

Santanam et al. (1990), in studies of coal and water slurry combustion for gas turbines, present an interesting strategy for combustion with hot gas cleanup, prior to coupling with an Allison 501-KM turbine. Ceramic candle filters may still be necessary.

\section{Biomass Feedstock Composition Ranges and Nature of Binding of Alkalies}

As discussed above, studies of coal, peat and MSW have revealed that different mechanisms are active in transporting different forms of alkali. Hence, it is important to know the form of alkali in biomass know the types of transport to be expected, the forms of alkali that will be transported, and to model ways to control the transport. Table 5, borrowed from Magasiner, and Table 6, borrowed from Hamrick (1991), give an idea of the range of biomass materials available. Table 7 (Greene 1988), shows some coal compositions.

First note that ash content-an indication of the amount of inorganic matter-varies widely in biomass, but tends to be less than coal. Temperate woods tend to have less than $1 \%$ ash. Higher values shown are probably due to contamination of the sawdust and wood waste during handling. Some grass species may yield more than $10 \%$ ash. Major elements are potassium, calcium and silicon.

Sodium and sulfur levels are lower than in most coals, but still significant. Chlorine is also present, though frequently not measured, and may be significant. The alkali-to-silicon ratio has been used as a predictor of the form of alkali release. High silica tends to produce larger solid particles that may cause erosion and high alkali tends to form a submicron alkali fume that may deposit as a liquid, causing fouling. Because sodium sulfate is a common culprit in hot corrosion, the lower sulfur in biomass may lead to different alkali behavior than that observed in coal. 
Table 4: Summary of Data on Alkali Metal Measurements Made on Various Types of Gasifiers Operated on Low Rank Coals (Sondreal, 1985)

\begin{tabular}{|c|c|c|c|c|c|c|c|c|c|c|c|c|}
\hline \multirow[t]{3}{*}{$\begin{array}{l}\text { Constituent analyzed } \\
\text { or computed }\end{array}$} & \multicolumn{4}{|c|}{$\begin{array}{l}\text { Alkali metal concentrations based } \\
\text { on loss from gasifier ash or slag }\end{array}$} & \multicolumn{4}{|c|}{$\begin{array}{l}\text { Alkali metal concentrations } \\
\text { based on analyses of gas } \\
\text { liquor condensates }\end{array}$} & \multicolumn{4}{|c|}{$\begin{array}{l}\text { Alkali metal concentrations based } \\
\text { on direct measurements in the } \\
\text { gas phase }\end{array}$} \\
\hline & \multicolumn{4}{|c|}{ Gasifier Typo } & \multicolumn{4}{|c|}{ Gasifier Type } & \multicolumn{4}{|c|}{ Gasifier type } \\
\hline & $\begin{array}{l}\text { Fixed Bed } \\
\text { Slagging }\end{array}$ & $\begin{array}{l}\text { Fixed } \\
\text { Bed Dry } \\
\text { Ash }\end{array}$ & $\begin{array}{l}\text { Fluid } \\
\text { Bed }\end{array}$ & Entrained & $\begin{array}{l}\text { Fixed Bed } \\
\text { Slagging }\end{array}$ & $\begin{array}{l}\text { Fixed } \\
\text { Bed } \\
\text { Dry } \\
\text { Ash }\end{array}$ & $\begin{array}{l}\text { Fluid } \\
\text { Bed }\end{array}$ & Entrained & $\begin{array}{l}\text { Fixed Bed } \\
\text { Slagging }\end{array}$ & $\begin{array}{l}\text { Fixed } \\
\text { Bed } \\
\text { Dry } \\
\text { Ash }\end{array}$ & $\begin{array}{l}\text { Fluid } \\
\text { Bed }\end{array}$ & Entrained \\
\hline \multicolumn{13}{|l|}{ ALKALIES IN COAL } \\
\hline $\begin{array}{l}\text { COAL AHS, WT PCT AS } \\
\text { REC }\end{array}$ & 7.63 & & & 7.9 & 6.2 & 6.1 & & & & 6.1 & 8.2 & 8.9 \\
\hline \multicolumn{13}{|l|}{$\begin{array}{l}\text { ALKALIES IN PRODUCT } \\
\text { GAS, PPM VN }\end{array}$} \\
\hline SODIUM AS Na & 1827 & & & & 8.8 & 10.0 & & & & 0.94 & 45 & \\
\hline POTASSIUM AS K & 87 & & & & NA & NA & NA & NA & NA & 3.03 & 1.6 & \\
\hline \multicolumn{13}{|l|}{$\begin{array}{l}\text { ALKALIES IN } \\
\text { COMBUSTION GAS, PPM } \\
\text { VN } N^{\prime}\end{array}$} \\
\hline SODIUM AS $\mathrm{Na}$ & 129 & & & 568 & 1.1 & 1.3 & & & & 0.1 & 5.7 & 35 \\
\hline POTASSIUM AS K & 11 & & & 31 & & & & & & 0.4 & 0.2 & 14 \\
\hline
\end{tabular}

Footnotes to Table

${ }^{1}$ Conversion from ppm in product gas to $\mathrm{ppm}$ in combustion gas are made using a divisor of 7.95 . This conversion factor was computed for dry ash fixed bed gasifier and a combustion temperature of $1800 \mathrm{deg}^{\circ} \mathrm{F}$. 
Table 5. Chemical and Physical Characteristics of Typical Fibrous Fuels (Magasiner, 1987)

\begin{tabular}{|c|c|c|c|c|c|c|c|c|c|c|c|}
\hline & & $\begin{array}{c}\text { Sunflower } \\
\text { Seed } \\
\text { Husks } \\
\text { (USA) }\end{array}$ & $\begin{array}{l}\text { Cotton } \\
\text { Stalks } \\
\text { (Israel) }\end{array}$ & $\begin{array}{l}\text { Cotton } \\
\text { Gin } \\
\text { Waste } \\
\text { (USA) }\end{array}$ & $\begin{array}{l}\text { Sugar Cane } \\
\text { Bagasse } \\
\text { (S. Africa) }\end{array}$ & $\begin{array}{l}\text { Sweet } \\
\text { Sorghum } \\
\text { Bagasse } \\
\text { (Austria) }\end{array}$ & $\begin{array}{c}\text { Refuse } \\
\text { Derived Fuel } \\
\text { (USA) }\end{array}$ & $\begin{array}{l}\text { Pine } \\
\text { Bark } \\
\text { (USA) }\end{array}$ & $\begin{array}{c}\text { Rice } \\
\text { Hulls } \\
\text { (Australia) }\end{array}$ & $\begin{array}{l}\text { Jack Pine } \\
\text { Waste } \\
\text { (USA) }\end{array}$ & $\begin{array}{l}\text { Cotton } \\
\text { Seed } \\
\text { Husks } \\
\text { (Israel) } \\
\end{array}$ \\
\hline \multicolumn{12}{|c|}{ Proximate } \\
\hline Ash & $\%$ & 3.8 & 3.8 & 8.4 & 1.7 & 2.7 & 8.9 & 1.5 & 21.5 & 1.3 & 2.3 \\
\hline Volatile & $\%$ & 66.1 & 57.3 & 73.7 & 37.9 & 34.8 & 51.6 & 36.5 & 35.7 & 44.6 & 68.7 \\
\hline Carbon & $\%$ & 19.6 & 22.1 & 7.6 & 5.4 & 8.5 & 13.8 & 12.1 & 34.8 & 14.2 & 19.3 \\
\hline Moisture & $\%$ & 10.5 & 16.8 & 10.3 & 55.0 & 54.0 & 21.9 & 50.0 & 8.0 & 40.0 & 9.7 \\
\hline \multicolumn{12}{|c|}{ Ultimate (daf) } \\
\hline C & $\%$ & 51.1 & 53.6 & 54.1 & 47.7 & 51.0 & 51.2 & 55.0 & 49.4 & 53.4 & 49.9 \\
\hline $\mathrm{H}$ & $\%$ & 6.3 & 5.2 & 8.2 & 5.9 & 5.6 & 6.7 & 5.8 & 6.2 & 5.9 & 6.3 \\
\hline 0 & $\%$ & 41.5 & 38.9 & 35.7 & 44.6 & 41.5 & 40.5 & 39.0 & 43.8 & 38.6 & 42.7 \\
\hline $\mathrm{N}$ & $\%$ & 0.9 & 1.3 & 1.6 & 1.8 & 1.8 & 1.0 & 0.1 & 0.3 & 0.1 & 1.0 \\
\hline $\mathbf{s}$ & $\%$ & 0.2 & 1.0 & 0.4 & $\cdots$ & 0.1 & 0.6 & 0.1 & 0.3 & 0.0 & 0.1 \\
\hline $\begin{array}{l}\text { GCV kJ/ } \\
\text { (daf) }\end{array}$ & & 20870 & 18110 & 17950 & 18950 & 18920 & 22465 & $\begin{array}{l}21 \\
630\end{array}$ & 17370 & 20755 & 19380 \\
\hline \multicolumn{12}{|c|}{ Ash Composition } \\
\hline $\mathrm{Na}_{2} \mathrm{O}$ & $\%$ & 0.4 & 2.0 & --- & 2.8 & 1.4 & 3.2 & 1.3 & 0.1 & -.- & 1.4 \\
\hline $\mathrm{K}_{2} \mathrm{O}$ & $\%$ & 39.3 & 30.0 & 11.3 & 2.9 & 5.0 & 2.1 & 6.0 & 1.2 & 4.1 & 42.0 \\
\hline $\mathrm{CaO}$ & $\%$ & 9.2 & 16.4 & 16.1 & 4.5 & 8.9 & 7.0 & 25.5 & 0.2 & 51.6 & 7.8 \\
\hline MgO & $\%$ & 7.2 & 5.2 & 8.0 & $\cdots$ & -- & 1.9 & 6.5 & 0.2 & 5.5 & 12.1 \\
\hline $\mathrm{Al}_{2} \mathrm{O}_{3}$ & $\%$ & 0.1 & 0.8 & 4.3 & 3.3 & 3.6 & 6.8 & 14.0 & 2.0 & 6.3 & 0.6 \\
\hline $\mathrm{Fe}_{2} \mathrm{O}_{3}$ & $\%$ & 0.6 & 0.5 & 3.3 & 2.4 & 2.2 & 4.9 & 3.0 & 0.1 & 5.0 & 0.9 \\
\hline $\mathrm{SiO}_{2}$ & $\%$ & 1.7 & 8.4 & 40.7 & 62.6 & 56.6 & 41.9 & 39.0 & 95.6 & 16.0 & 0.4 \\
\hline \multicolumn{12}{|c|}{ Ash Fusion Temp ${ }^{\circ} \mathrm{C}$} \\
\hline IDT & & 940 & -- & --. & -.- & 1236 & +1400 & 1193 & +1400 & 1343 & 1390 \\
\hline HT & & 980 & --- & 1195 & 1350 & 1244 & +1400 & 1277 & +1400 & +1400 & +1400 \\
\hline FT & & 1020 & 1200 & --- & $\cdots$ & 1252 & +1400 & 1266 & +1400 & +1400 & +1400 \\
\hline
\end{tabular}


Table 6: Analysis of Red Boiling Springs Turbine Fuels (Hamrick 1991)

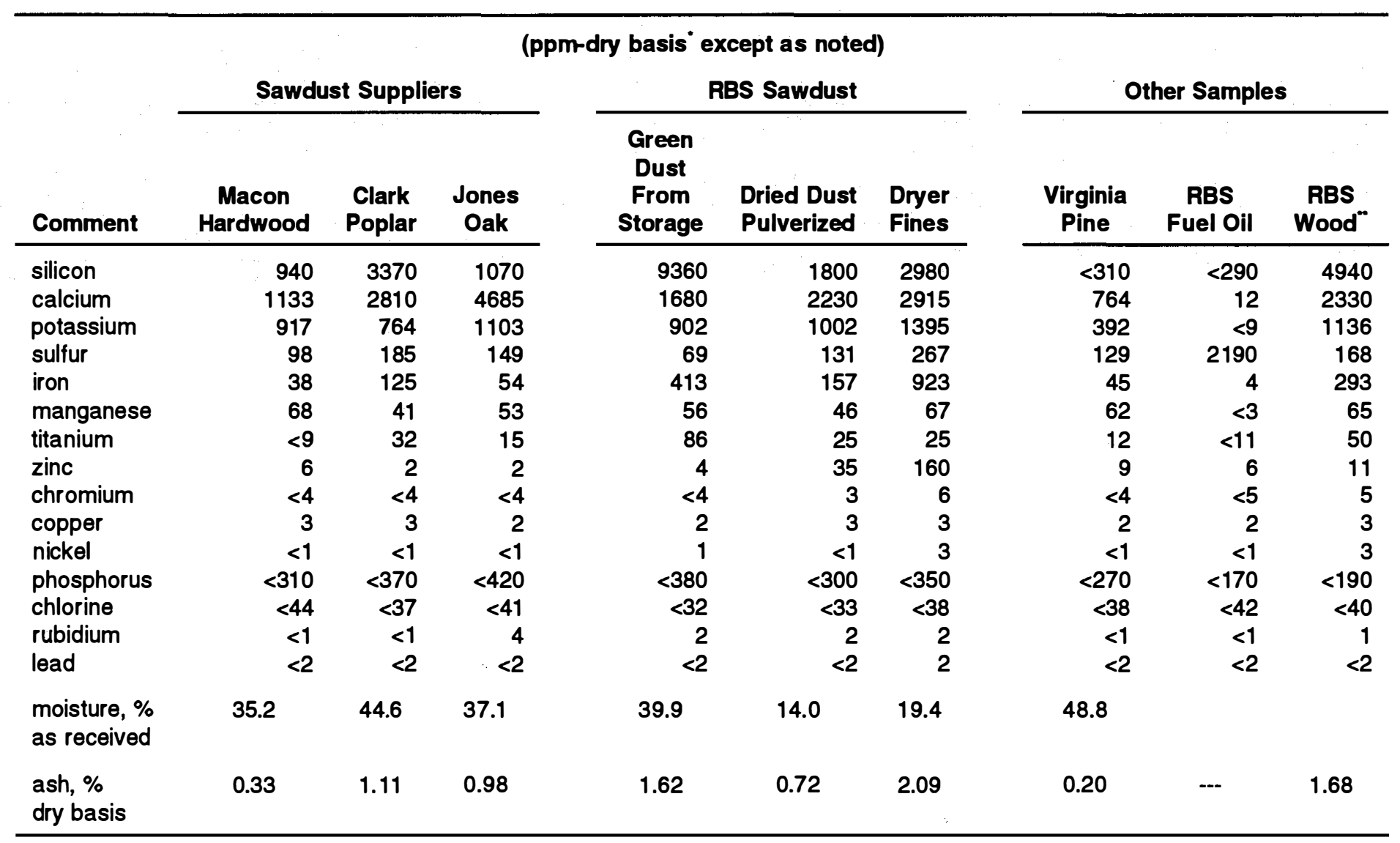

* Elemental analyses by scanning $x$-ray fluorescence spectrometer. Values cited as < indicate the level that would have been detetable above background noise at the time a particular value was determined.

** As received basis. Same sample identified as RBS Wood in Table D.1. 
Table 7: Chemical Characteristics of Some Coals (Greene, 1988)

\begin{tabular}{|c|c|c|c|c|c|c|}
\hline & & Boulah & Decker & Sewickley & $\begin{array}{c}\text { Western } \\
\text { Bituminous }\end{array}$ & Illinois No. 6 \\
\hline \multicolumn{7}{|c|}{ Proximate } \\
\hline $\begin{array}{l}\text { Ash } \\
\text { Volatile } \\
\text { Carbon } \\
\text { Moisture }\end{array}$ & $\begin{array}{l}\% \\
\% \\
\% \\
\%\end{array}$ & $\begin{array}{r}5.5 \\
28.3 \\
32.9 \\
33.3\end{array}$ & $\begin{array}{r}3.8 \\
30.5 \\
40.0 \\
25.7\end{array}$ & $\begin{array}{r}14.2 \\
37.5 \\
45.2 \\
3.1\end{array}$ & 11.3 & $\begin{array}{c}7.8 \\
33.7 \\
48.6 \\
9.9\end{array}$ \\
\hline \multicolumn{7}{|c|}{$\begin{array}{l}\text { Ultimate } \\
\text { (Dry, ash free) }\end{array}$} \\
\hline $\begin{array}{l}C \\
H \\
O \\
N \\
S\end{array}$ & $\begin{array}{l}\% \\
\% \\
\% \\
\% \\
\%\end{array}$ & $\begin{array}{r}71.9 \\
10.4 \\
15.6 \\
0.9 \\
1.2\end{array}$ & $\begin{array}{r}76.2 \\
8.9 \\
13.2 \\
1.2 \\
0.5\end{array}$ & $\begin{array}{r}79.7 \\
5.5 \\
7.9 \\
1.1 \\
5.8\end{array}$ & $\begin{array}{c}80.0 \\
5.8 \\
12.0 \\
1.5 \\
0.7\end{array}$ & $\begin{array}{c}80.9 \\
5.4 \\
9.9 \\
1.8 \\
2.0\end{array}$ \\
\hline \multicolumn{7}{|c|}{ Ash Composition } \\
\hline $\begin{array}{l}\mathrm{Na}_{2} \mathrm{O} \\
\mathrm{K}_{2} \mathrm{O} \\
\mathrm{CaO} \\
\mathrm{MgO} \\
\mathrm{Al}_{2} \mathrm{O}_{3} \\
\mathrm{Fe}_{2} \mathrm{O}_{3} \\
\mathrm{SiO}_{2} \\
\mathrm{TiO}_{2} \\
\mathrm{SO}_{3}\end{array}$ & $\begin{array}{l}\% \\
\% \\
\% \\
\% \\
\% \\
\% \\
\% \\
\% \\
\%\end{array}$ & $\begin{array}{r}14.6 \\
0.0 \\
20.7 \\
6.7 \\
12.7 \\
8.6 \\
12.8 \\
0.6 \\
25.9\end{array}$ & $\begin{array}{r}8.9 \\
0.4 \\
16.0 \\
3.9 \\
17.0 \\
6.3 \\
22.1 \\
1.9 \\
20.0\end{array}$ & $\begin{array}{r}0.9 \\
1.9 \\
4.3 \\
0.9 \\
19.7 \\
32.5 \\
34.1 \\
0.9 \\
4.4\end{array}$ & $\begin{array}{c}1.7 \\
2.3 \\
2.4 \\
0.9 \\
22.7 \\
18.7 \\
49.0 \\
1.2 \\
1.0 \\
\end{array}$ & $\begin{array}{c}1.5 \\
1.6 \\
5.1 \\
1.0 \\
17.4 \\
3.0 \\
64.5 \\
0.9 \\
2.9 \\
\end{array}$ \\
\hline
\end{tabular}


The form in which a given element of interest appears in the biomass is less clear-cut, for most appear in multiple forms, only some of which are understood, and the relative importance of various forms is not clear. Nearly all metals have a role in enzymes, but that is not the dominant form for most metals. They may also be bound to organic or organo-phosphate acids (e.g. phytic acid), be bound to organic acid groups in fixed structures, be in water solution with inorganic counter ions, or be present as mineral deposits. Common inorganic counter ions in wood, for example, are carbonates, oxalates, phosphates, silicates and sulfates (Gray \& Parham 1982).

Calcium seems to be present primarily bound to uronic acid groups in cell walls, although much may be in vacuoles in leaves (Marschner, 1986, Sutcliffe, 1974). Evidence for this binding is work on Populus trichocarpa sapwood that shows that Ca is not removed by hot water (DeGroot,1988), but almost completely removed by soaking in hydrochloric acid (Hshieh, 1989). It also tends to form considerable deposits with oxalate in a variety of species (Wattendorf, 1969; Marschner, 1986; p.253, Hillis, 1979; Scurfield, 1973; Howard, 1971) that is insoluble in water but soluble in acid. Deposits of calcium carbonate have been found in Populus deltoides (Scurfield 1973). Calcium carbonate is found in Acer saccharum heartwood (Mia 1969).

Magnesium is similarly not water extractable from wood (DeGroot 1988) and only partly removed by acid extraction. It is, of course, central to chlorophyll that is present in photosynthetically active biomass. However, even in leaves only 10-20 percent of the magnesium is in chlorophyll and it may be present in solution in vacuoles (Marschner 1986).

On the other hand, potassium is mostly present in water solution in vacuoles and is not a constituent of any organic structure (Sutcliffe 1974; Marschner 1986), although it is active in many enzymes. It may be associated with nitrate in vacuoles, perhaps nitrate or malate during xylem transport. It is generally a weakly associated charge carrier and easily exchanged (Marschner 1986). Accordingly, as seen in Table 8, it can be extracted from Populus trichocarpa essentially completely by hot water (DeGroot 1988) though about a percent of it remains even after acid washing (Table 9 and 10).

In some places the work of DeGroot and Petch (1986) seems to imply that potassium is bound to uronic acid groups in cell walls. However, this is not necessarily true. (Qiu and Richards 1989). It is generally agreed that calcium is bound to uronic acid groups in cell walls. However, the following facts show that the binding of potassium is different than that of calcium: 1) potassium alone is removed from Populus trichocarpa by hot water; 2) calcium is not increased by ion exchange although potassium is increased by this means. What is not clear is the nature of the binding of potassium. Clearly potassium can occupy calcium sites but the reverse is not true. The exchanged potassium may be binding exclusively to calcium sites. In other words, there may not be fixed potassium sites in the original wood-it might be in solution. Further experimental work to elucidate the form of potassium in populus and other woods would be helpful to this study.

Sodium seems to function mainly as a replacement for potassium (Marschner 1986), though it is present at lower levels. Chlorine is also highly mobile, and exists as free chloride (Marschner 1986).

Although silicious acid has a reasonable solubility $\left(2 \mathrm{mM}\right.$ at $\left.25^{\circ} \mathrm{C}\right)$ (Marschner 1986), silicacious deposits in biomass are well known (Hillis 1979). Maize may contain 1\% silica both as large deposits (opals) and as deposits in cell walls (Sutcliffe 1974).

Sulfur may be present as inorganic sulfate. It may also be present as sulfolipids in membranes or polysaccharides. There are also phospho-sulfates and iron-sulfur proteins. In cotton leaves from a well nourished plant, the amount of sulfate and organic sulfur are comparable (Marschner 1986). 
Table 8. Composition of Cottonwood and Treated Cottonwood Samples (DeGroot 1988)

\begin{tabular}{|c|c|c|c|c|c|c|}
\hline \multirow[b]{2}{*}{ Sample } & \multirow{2}{*}{$\begin{array}{c}\text { Ash } \\
\text { Yiold (\%) }\end{array}$} & \multicolumn{5}{|c|}{ Principle Inorganic Species (\%) } \\
\hline & & $\mathbf{N a}$ & $\mathbf{K}$ & Mg & $\mathbf{C a}$ & Co \\
\hline Untreated Sapwood & 0.51 & -- & 0.10 & 0.02 & 0.15 & $\cdots$ \\
\hline $\begin{array}{l}\text { lon-exchanged } \\
\text { Sapwood }\end{array}$ & 0.02 & -.. & -.. & --. & 0.01 & $\ldots$ \\
\hline Acid-Washed & 0.41 & 0.03 & 0.28 & -- & 0.02 & $\cdots$ \\
\hline K-exchanged & 0.34 & 0.01 & -- & $-\cdots$ & 0.14 & $\ldots$ \\
\hline $\begin{array}{l}\text { Ca-exchanged } \\
\text { Co-exchanged }\end{array}$ & 0.34 & -- & -- & $-\cdots$ & 0.01 & 0.23 \\
\hline $\begin{array}{l}\text { Water-extracted } \\
\text { Sapwood }\end{array}$ & 0.26 & -- & --- & 0.02 & 0.16 & - \\
\hline
\end{tabular}

alon-exchanged samples were acid washed $\left(\mathrm{H}^{+}\right.$-exchanged prior to treatment.

'No value $(---)=<50$ ppm.

Phosphorus may be present as sugar-phosphates, such as phytic acid-hexainositol phosphoric acid. This tends to form salts with calcium, magnesium and potassium. ATP, of course, is a common sugarphosphate compound. It may also be present in phospholipids or as inorganic phosphates (Marschner 1986).

Little is known about the form of alkali generated when biomass is pyrolyzed to make oil. Table 11 (Czernik 1992) shows alkali in the feedstock and oil generated on the NREL vortex reactor at a reactor wall temperature of $625^{\circ} \mathrm{C}$ and exit gas temperature of $525^{\circ} \mathrm{C}$. The residence times in the reactor and vapor cracker were about $0.5 \mathrm{~s}$ each. The carrier gas was nitrogen. It is apparent that much of the alkali is lost, presumably to the char. However, the levels are still far in excess of turbine specifications. It is not known what phase-water, organic, or suspended char - has the greater portion of the alkali. In fact, some of the differences as a function of vapor-cracker temperature may be due to non-representative sampling of this heterogeneous mixture.

The critical question in all the above-mentioned properties is, how will it affect the release of this material during gasification? No definitive answers can be given, but some general statements can be made. Most elements are present in both inorganic and organic forms. Therefore, it seems reasonable to expect both forms to come off initially in gasification. The notable exception is potassium which seems to be primarily in solution and therefore is expected to come off in inorganic form, perhaps as chlorides, free metal, or oxides (which would then be reduced). Also, almost any species can be carried off in fine particulate form under high gas flow in rapid heating.

\section{E. Coal and Biomass Differences and Their Implications for Alkali Behavior}

Coal results have been presented earlier in this report, but, as was alluded to earlier, their relevance is in question because of the differences in the structures and compositions of coal and biomass and the differences in the forms of the alkali. Therefore in this section we will summarize the relevant differences and speculate on their effect on alkali behavior. 
Table 9. Alkali in Populus trichocarpa (Pan, 1989)

\begin{tabular}{lrrrrrr}
\hline & Ca & Mg & $\mathbf{P}$ & $K$ & $\mathbf{N a}$ & Zn \\
\hline Original Wood & 1500 & 200 & 140 & 1000 & 30 & 9 \\
Acid-Washed & 12 & 1 & 8 & 5 & 7 & 0 \\
Ca Exchanged & 1399 & 1 & 11 & 45 & 43 & 11 \\
K Exchanged & 12 & 4 & 8 & 2122 & 0 & 0 \\
\hline
\end{tabular}

Table 10. Alkali in Populus trichocarpa (Hshieh, 1989)

\begin{tabular}{lcccccccccc}
\hline & Al & Ca & Co & Cu & Fo & Mg & P & K & Na & Zn \\
\hline Cottonwood & 8 & 1500 & 4 & 4 & 2 & 200 & 140 & 1000 & 30 & 9 \\
$\begin{array}{l}\text { Acid } \\
\text { Washed }\end{array}$ & 2 & 13 & 0 & 0 & 3 & 2 & 10 & 15 & 15 & 3 \\
\hline
\end{tabular}

Table 11. Alkali Content of Pyrolysis Feedstocks and Oils (Czernik 1992)

\begin{tabular}{lcrrrr}
\hline Material & $\begin{array}{c}\text { Temp. of } \\
\text { Vapor } \\
\text { Cracker }\end{array}$ & $\begin{array}{r}\text { Ash } \\
\%\end{array}$ & $\begin{array}{r}\text { Na } \\
\text { ppmw }\end{array}$ & $\begin{array}{r}\mathbf{K} \\
\text { ppmw }\end{array}$ & $\begin{array}{r}\text { Ca } \\
\text { ppmw }\end{array}$ \\
\hline Oak & & .67 & 120 & 640 & 1700 \\
Oak Oil & $600^{\circ} \mathrm{C}$ & $<.05$ & 38 & 32 & 33 \\
& $650^{\circ} \mathrm{C}$ & $<.05$ & 36 & 24 & 31 \\
& $700^{\circ} \mathrm{C}$ & $<.05$ & 52 & 35 & 23 \\
Switchgrass & & 6.05 & 340 & 5000 & 3300 \\
Switchgrass & $460^{\circ} \mathrm{C}$ & .79 & 20 & 740 & 490 \\
Oil & $525^{\circ} \mathrm{C}$ & .95 & 40 & 1380 & 660 \\
& $605^{\circ} \mathrm{C}$ & .12 & 40 & 580 & 590 \\
\hline
\end{tabular}

The primary difference in the inorganic forms of minerals is the presence of clays (kaolinite, illite, montmorillonite) in coal. These aluminosilicates may effectively sequester the alkali during combustion, to make the coal burn cleaner than biomass with an equivalent level of alkali. Much of the potassium in coal is firmly bound to illite and is not ion-exchangeable, lowering the level of potassium available for release during gasification and combustion. Coal also contains quartz that may sequester alkali as well. However, some biomass species produce deposits of silica that may also function to sequester alkali. In addition, coal tends to have higher levels of sulfur, particularly as iron sulfides, than does biomass. This will form sulfates during combustion and increase the hot corrosion caused by coal. The pyrites may also serve to mobilize the iron. Some biomass contains high levels of chlorine that will serve to mobilize the alkali more effectively than for most coals. Calcium oxalate is a common deposit in some biomass species but is not mentioned in the coal literature. However, it is not clear what the role of calcium oxalate is in mobilizing calcium. In contrast, the calcium in carbonate and mixed carbonate forms in coal probably acts to raise ash fusion temperatures and reduce bed agglomeration. 
The organic binding of metals may be fairly similar because both contain organic acid groups. However, it is not clear how effectively particular metals may be chelated by structures peculiar to coal or biomass, or how volatile or thermally stable the resulting complexes may be. Also, biomass has a higher oxygen content that causes a significantly more oxidizing environment in the fuel and reduces the release of alkali as metal. Most of the organically bound alkali in coal is sodium. As mentioned above, potassium is the major alkali in biomass and is variously reported in water solution or, in some wood literature, as loosely bound to the cell walls. Organically bound sodium probably behaves in a manner similar to organically bound potassium.

Lastly, the form and combustion properties differ. Coal is usually crushed to particles less than $100 \mu \mathrm{m}$ in diameter whereas biomass is frequently in the form of chips (e.g. wood) that may be $1 \mathrm{~cm}$ or so in major dimension. Coal also has a larger heating value than biomass. As a result of these factors, coal may gasify or burn hotter, faster and more violently, promoting the release of alkali vapors and fly ash. In a large biomass chip, there also might be more effective sequestering of metals as they migrate to the surface from the interior of the chip. The situation with biomass pyrolysis oil spray combustion is yet again different, with partial segregation of mineral matter combined with rapid combustion of atomized liquid.

In summary, there are clear differences in the form of alkali in biomass and coal, but it is not apparent what the net effect of these differences will be on the release of alkali in gasification and combustion environments. Hence, the behavior of alkali from biomass during gasification and combustion needs to be studied to successfully implement biomass fired turbines.

\section{F. Fouling and Slagging Experience in Biofuel-Fired Boilers and Turbines}

Although there seems to be no published work that tries to directly measure the evolution of alkali vapor species in biomass gasification and combustion, there is other relevant work that sheds light on part of the problem. Experimental turbines have run off biomass combustors and biomass pyrolysis oil. Utilities are currently operating boilers on biomass fuels. The experimental turbine tests were not run long enough to detect corrosion problems. The boilers are much more rugged than turbine systems and utilities tend not to provide detailed test results, but the temperature and fuel for which slagging and fouling occurred are available for many of these systems (Miles 1993). These provide some guidelines for conditions that will cause fouling and slagging in turbines.

Hamrick (1991) and Ragland (1989) have both operated turbines on hot gases from biomass combustors. Neither used gasification. Hamrick's systems were a $400 \mathrm{~kW}$ Garrett IE 200-831 and a 3 MW Allison T-56. Both systems burned sawdust in suspension. Ragland's system was a bench-scale, down-draft combustor fueled by wood chips and running a helicopter turbine. Both found considerable deposition on the turbine.

The Garrett turbine was fueled primarily by yellow pine sawdust. The maximum temperature of gases leaving the combustor was approximately $1500^{\circ} \mathrm{F}\left(815^{\circ} \mathrm{C}\right)$. A Dual or triple cyclone was used to remove particulates. After 210 hours of operation there were moderate hard deposits on the first two stages of the turbine blades but no detectable corrosion or erosion. An identical turbine was successfully operated for 365 hours (Hamrick 1991).

Typical fuel in the T-56 was sawdust from tulip poplar and red and white oak. The ash was typically $1.7 \%$ by mass (dry), and a typical ash analysis is shown below in Table 12 . The high ash, silica, and alumina suggest contamination of the fuel with dirt. The moisture was 35-50\% when fresh and up to $60 \%$ moisture if stored in rain. It was dried to about $25 \%$ moisture to reduce char formation. 
Hamrick found that by keeping the temperature below $1450^{\circ} \mathrm{F}\left(788^{\circ} \mathrm{C}\right)$ in the $\mathrm{T}-56$, hardening and firm adhesion of the deposits in the turbine was avoided. The level of deposition was much lower than at $1500^{\circ} \mathrm{F}\left(815^{\circ} \mathrm{C}\right)$, at which point sustained runs were not possible because of rapid deposition. However, even at $1450^{\circ} \mathrm{F}$ the power output would begin to decline after only 26 hours, due to deposition. Some deposits were due to minerals from the injected water being carried through the cyclone. Typical conditions were $5500 \mathrm{lbs}$ of wood per hour, $34 \mathrm{lbs}$ of air per second, 12 gal water per minute, and a turbine inlet temperature of $1273^{\circ} \mathrm{F}\left(689^{\circ} \mathrm{C}\right)$. The T-56 was also run for ten hours on bagasse at 1400 $1450^{\circ} \mathrm{F}\left(760-788^{\circ} \mathrm{C}\right)$ and $25-75 \%$ of rated engine speed-the deposition was about the same as for wood. The bagasse had unusually high ash (see Table 13) that could have been due to extended weathering.

Analyses were done on the deposits formed in the T-56. As can be seen from Table 14, the deposits are enriched in sulfur, depleted in silicon and usually enriched in potassium relative to the calcium compared to the original fuel. The amount of sulfur emitted by the turbine was found to be higher than could be accounted for by the sulfur in the wood fuel. The likely source of the excess sulfur is the fuel oil, co-fired during turbine start-up, for which $\mathrm{x}$-ray fluorescence analysis indicated $2190 \mathrm{ppm}$ of sulfur. X-ray diffraction showed that the major crystalline components of the deposits were potassium sulfate (m.p. $1069^{\circ} \mathrm{C}$ ), calcium carbonate, fairchildite $\left[\mathrm{K}_{2} \mathrm{Ca}\left(\mathrm{CO}_{3}\right)_{2}\right]$, and spurrite $\left[\mathrm{Ca}_{5}\left(\mathrm{SiO}_{4}\right)_{2} \mathrm{CO}_{3}\right]$. Less than $30 \%$ of the deposit material was crystalline. Bench tests showed that wood alone does not tend to form deposits, but that wood mixed with fuel oil containing sulfur does give deposits. Adding calcium oxide to the wood/oil mixture in a calcium/sulfur molar ratio of $3 / 1$ eliminated the deposition.

Ragland's system comprised a downdraft combustor and an Allison 250-C20B gas turbine (Ragland 1989). This system has no cyclone, and significant deposition was found. The normalized nozzle area index number of Kimura et.al. (1987) was found to decrease by $4.2 \% / 1000 \mathrm{~kg}$ of wood or $0.19 \% / \mathrm{hr}$ for the turbine as a whole, (Misra 1992). The deposits on the nozzles were loosely attached and flaked off, but those on the turbine were more firmly attached and required soaking to remove. The system was run on primarily yellow poplar for 130 hours at bed outlet temperatures of $327-699^{\circ} \mathrm{C}$ (Ragland, 1989). However, temperature data for four out of the 26 runs were missing so temperatures may have exceeded this range. Samples of deposits were collected from the turbine and analyzed by inductively coupled plasma emission

Table 12. Ash Composition of Sawdust Fuel

\begin{tabular}{lr}
\multicolumn{2}{c}{$\begin{array}{c}\text { Red Boiling Springs Fuel (Hamrick 1991), } \\
\text { Mass \% by ICP Spectroscopy, as oxides }\end{array}$} \\
\hline Ash Component & $\begin{array}{c}\text { Mass, } \\
\%\end{array}$ \\
& 52.8 \\
$\mathrm{SiO}_{2}$ & 17.0 \\
$\mathrm{CaO}$ & 6.9 \\
$\mathrm{~K}_{2} \mathrm{O}$ & 3.9 \\
$\mathrm{Al}_{2} \mathrm{O}_{3}$ & 2.2 \\
$\mathrm{Fe}_{2} \mathrm{O}_{3}$ & 2.2 \\
$\mathrm{MgO} \mathrm{O}$ & 1.0 \\
$\mathrm{P}_{2} \mathrm{O}_{5}$ & 1.0 \\
$\mathrm{SO}_{3}$ & $\mathrm{NA}$ \\
$\mathrm{Na}_{2} \mathrm{O}$ & $<1.0$ \\
$\mathrm{TiO}_{2}, \mathrm{MnO}_{2}, \mathrm{BaO}, \mathrm{CuO}, \mathrm{ZnO}, \mathrm{NiO}, \mathrm{SrO}, \mathrm{Cr}_{2} \mathrm{O}_{3}$ & \\
\hline
\end{tabular}


Table 13. Elemental Composition of Sugarcane Sample (Hamrick 1991)

\begin{tabular}{|c|c|}
\hline Element & $\begin{array}{r}\text { Sugar Cane } \\
\text { Bagasse, Wt } \% \text { as } \\
\text { received }\end{array}$ \\
\hline Carbon & 42.6 \\
\hline Hydrogen & 5.10 \\
\hline Nitrogen & 0.59 \\
\hline Oxygen (a) & 37.9 \\
\hline Calcium & 0.882 \\
\hline Potassium & 0.354 \\
\hline Silicon & 2.94 \\
\hline Magnesium & 0.124 \\
\hline Sulfur & 0.073 \\
\hline Iron & 0.152 \\
\hline Aluminum & 0.29 \\
\hline Phosphorus & 0.034 \\
\hline Manganese & 0.070 \\
\hline Sodium & 0.098 \\
\hline Chromium & 0.007 \\
\hline Barium & 0.004 \\
\hline Nickel & 0.005 \\
\hline Zinc & 0.008 \\
\hline Boron & 0.002 \\
\hline Titanium & 0.015 \\
\hline Strontium & 0.003 \\
\hline Copper & 0.002 \\
\hline Moisture (by TGA) & 5.8 \\
\hline Fixed Carbon (b) & 1.4 \\
\hline Ash & 13.8 \\
\hline \multicolumn{2}{|c|}{$\begin{array}{l}\text { ND = not detected } \\
\text { (a) by difference, } 100-(\mathrm{C}+\mathrm{H}+\mathrm{N}+\mathrm{Ash})= \\
\text { Oxygen } \\
\text { (b) believed low due to suspected air leakage } \\
\text { TGA = Thermogravimetric Analysis }\end{array}$} \\
\hline
\end{tabular}

spectroscopy. These tests showed that the proportion of potassium and sodium decreased by more than a factor of two going from entrance to exit of the turbine and calcium and magnesium increased by a factor of ten. Sulfur, iron, phosphorus and aluminum were also reported. An x-ray diffraction pattern from a stator in about the middle of the turbine showed potassium sulfate, calcium oxide, magnesium oxide, magnesium phosphate, and perhaps a calcium magnesium silicate $\left[\mathrm{Ca}_{3} \mathrm{Mg}\left(\mathrm{SiO}_{4}\right)_{2}\right]$. This is not surprising since potassium, calcium, magnesium, and sulfur are the major elements at this point in the turbine and the K/S molar ratio is very close to $2 / 1$. At the entrance to the turbine the $\mathrm{K} / \mathrm{S}$ molar ratio is more than 3/1, indicating the presence of another potassium species. About $40 \%$ of the mass of the sample is accounted for in the ICPES analysis. The remainder cannot be made up by reasonable oxides, so a considerable amount of silicon was probably present.

The turbine operated for another 122 hours on aspen and the deposits were analyzed again. An almost opposite trend was seen, more calcium was present at the inlet side of the turbine and slightly more potassium was present toward the outlet end of the turbine. Overall fractions of potassium and sulfur were 
Table 14. Elemental Analyses of Red Boiling Springs Ash Deposit Samples (Hamrick 1991)

\begin{tabular}{|c|c|c|c|c|c|c|c|}
\hline \multicolumn{8}{|c|}{ Turbine Deposits } \\
\hline Element & RBS Wood Fuel & Cyclone Ash & 09/86 & $04 / 87$ & $07 / 88$ & $\# 1^{\text {** }}$ & $\begin{array}{l}03 / 89^{\star} \\
\# 2^{* \star \star}\end{array}$ \\
\hline $\mathrm{CaO}$ & 17.0 & 19.7 & 19.4 & 22.0 & 33.4 & 21.4 & 30.1 \\
\hline $\mathrm{K}_{2} \mathrm{O}$ & 6.4 & 7.2 & 35.1 & 31.7 & 17.3 & 29.2 & 15.3 \\
\hline $\mathrm{SO}_{3}$ & 1.0 & 0.5 & 25.8 & 15.6 & 10.9 & 11.2 & 5.8 \\
\hline $\mathrm{SiO}_{2}$ & 52.2 & 50.4 & 4.1 & 5.2 & 8.1 & 2.9 & 5.4 \\
\hline $\mathrm{MgO}$ & 2.2 & 2.3 & 0.7 & 1.3 & 2.4 & 2.1 & 3.0 \\
\hline $\mathrm{Fe}_{2} \mathrm{O}_{3}$ & 2.2 & 3.1 & 1.2 & 1.2 & 2.3 & 1.1 & 1.6 \\
\hline $\mathrm{A}_{2} \mathrm{O}_{3}$ & 3.9 & 4.6 & 0.8 & 0.9 & 1.6 & 0.5 & 1.0 \\
\hline $\mathrm{P}_{2} \mathrm{O}_{5}$ & 1.0 & 1.4 & 1.4 & 0.9 & 1.2 & 0.8 & 1.0 \\
\hline $\mathrm{MnO}_{2}$ & 0.5 & 0.6 & 0.2 & 0.4 & 0.5 & 0.5 & 0.6 \\
\hline $\mathrm{Na}_{2} \mathrm{O}$ & NA & 1.4 & --- & 1.2 & 0.6 & 0.6 & 0.6 \\
\hline $\mathrm{Cr}_{2} \mathrm{O}_{3}$ & 0.04 & 0.2 & 2.6 & 0.3 & 0.4 & 0.5 & 0.3 \\
\hline $\mathrm{BaO}$ & 0.3 & 0.2 & 0.1 & 0.1 & 0.2 & 0.2 & 0.2 \\
\hline $\mathrm{NiO}$ & 0.05 & 0.1 & 0.1 & 0.1 & 0.2 & 0.1 & 0.1 \\
\hline $\mathrm{ZnO}$ & 0.09 & 0.2 & 2.0 & 0.6 & 0.1 & 0.5 & 0.4 \\
\hline $\mathrm{B}_{2} \mathrm{O}_{3}$ & $\cdots$ & 0.3 & 0.9 & 0.6 & 0.6 & 0.3 & 0.6 \\
\hline $\mathrm{TiO}_{2}$ & 0.5 & 0.6 & 0.04 & 0.06 & 0.1 & 0.03 & 0.05 \\
\hline Sro & 0.06 & 0.07 & 0.05 & 0.06 & 0.09 & 0.06 & 0.09 \\
\hline $\mathrm{CuO}$ & 0.01 & 0.05 & 0.09 & 0.10 & 0.09 & 0.04 & 0.05 \\
\hline CdO & -.. & -.- & 0.04 & 0.02 & -.. & --. & --- \\
\hline
\end{tabular}

All analyses performed by inductively coupled plasma-atomic emission spectrometry

NA $=$ Not analyzed

-.- = Concentration below limits of detection

* Samples taken after operation with water injection (non-deionized water)

** \#1. Tan-gray powder removed from turbine blades

*** \#2. Gray crusted particulate deposti removed from turbine entrance 
lower in these aspen runs, while calcium and phosphorus were higher. One difference cited was the ash content,--poplar, $0.7 \%$, aspen, $0.3 \%$. Also $\mathrm{K}$ content in the ash is lower in poplar and a thinner bed was used in the aspen runs. The thinner bed may have caused less coalescence of liquid droplets of potassium species that would then deposit by diffusive mechanisms in the turbine rather than impaction, and larger solid Ca particulates may have escaped, tending to deposit by impaction earlier in the turbine. Species seen by $\mathrm{x}$-ray diffraction were $\mathrm{CaO}, \mathrm{MgO}, \mathrm{K}_{2} \mathrm{SO}_{4}, \mathrm{Ca}(\mathrm{OH})_{2}, \mathrm{Zn}_{2} \mathrm{Mn}_{3} \mathrm{O}_{8}, \mathrm{Mg}_{6} \mathrm{MnO}_{8}, \mathrm{Ca}_{2} \mathrm{Fe}_{7} \mathrm{O}_{11}, \mathrm{CaFe}_{3} \mathrm{O}_{5}$, $\mathrm{KCaPO}_{4}, \mathrm{CaFe}_{4} \mathrm{O}_{7}, \mathrm{Ca}_{2} \mathrm{P}_{2} \mathrm{O}_{7}$, and $\mathrm{K}_{3} \mathrm{AlO}_{3}$.

The reports of utility boiler experience come from the Biomass Combustion Conference held January 2830, 1992 in Reno, Nevada (NREL 1992). Proceedings will be published by the Electric Power Research Institute. Selected papers appear in Biomass and Bioenergy (1993). These reports usually do not discuss mechanistic aspects and some presenters seemed reluctant to give much specific data. Also, the conditions are not identical to those found in turbines. However, they do give conditions under which slagging occurs and the feedstocks that are prone to slagging.

Circulating fluidized bed combustors were reported to experience agglomeration and defluidization. Almond and pistachio shells were identified as some of the fuels with high sodium and potassium that lead to agglomeration. Typical operating temperatures from the CE Lurgi design in Fresno, California were $1575-1750^{\circ} \mathrm{F}\left(857-954^{\circ} \mathrm{C}\right)$ (Hollenbacher 1992).

Bubbling CFBC's have dealt with similar problems. The Chinese Station plant was designed to burn wood and urban wood waste. The El Nido, Chowchilla, and Madera plants were designed to burn 100\% agricultural residues such as rice straw, wheat straw, cotton stalk and almond tree prunings. A normal operating temperature has been $1600-1650^{\circ} \mathrm{F}\left(871-899^{\circ} \mathrm{C}\right)$. In their early use, superheater fouling occurred due to slagging of ash from buming in the freeboard above the bed, causing excessive temperatures. Steps to keep the freeboard temperature down to $1600-1650^{\circ} \mathrm{F}$ alleviated the problem. Limestone may be added to the bed to reduce slagging (Hollenbacher 1992). The next generation, the Delano, California facility, had a combustor exit gas temperature of about $1750^{\circ} \mathrm{F}\left(954^{\circ} \mathrm{C}\right)$ (Hanson 1992).

During pilot plant testing prior to designing the El Nido and Chowchilla units, softening ash from cotton stalks was found at less than $1400^{\circ} \mathrm{F}\left(760^{\circ} \mathrm{C}\right)$, necessitating vapor temperatures of less than $1800^{\circ} \mathrm{F}$ $\left(982^{\circ} \mathrm{C}\right)$ to prevent hard ash deposits on the boiler tubes. Progressive buildup of sodium and potassium was also found in the bed of the pilot facility. It was determined that adding limestone to the bed raised the ash softening temperature by several hundred degrees (Hanson 1992).

A wood and rice straw atmospheric pressure fluidized bed experienced agglomeration whenever the temperature exceeded $800^{\circ} \mathrm{C}$ or the blend exceeded $50 \%$ rice straw (Salour 1992). Phase diagrams suggesting partial melting for a rice-straw-ash like system at less than $600^{\circ} \mathrm{C}$ were mentioned (Levin 1964), with $\mathrm{Na}_{2} \mathrm{O}, \mathrm{K}_{2} \mathrm{O}, \mathrm{Li}_{2} \mathrm{O} \mathrm{CaO}$ and $\mathrm{MgO}$ all contributing to the lowering of ash fusion temperatures in silica systems. The minimum ash fusion temperatures were found at a base-to-acid ratio of about 0.3 , contrary to 0.75 cited from coal work.

A Yanke fluidized bed system running at $1500^{\circ} \mathrm{F}\left(815^{\circ} \mathrm{C}\right)$ in the lower fumace still had some clinkering, attributed to sodium or potassium perhaps from glues in waste wood (Biomass 1992).

One operator claimed good correlations were being obtained with slagging and fouling behavior by using the base/acid ratio, total alkali, and total salts. They were optimizing a predictive model based on coal formulas (Coe 1992). As did others, they found wood chips to be best, followed by woody fruit and nut tree chips, vine prunings, nut shells and hulls, and field crops. 
Design engineers contributed fairly similar experience to that of the operators. One recommended maximum furnace exit temperatures of $1650-1750^{\circ} \mathrm{F}\left(899-954^{\circ} \mathrm{C}\right)(\mathrm{McC}$ allum 1992). Another noted ash fusion temperatures down to $760^{\circ} \mathrm{C}$ for some prunings, straws, etc. (Miles 1992), and using lime and dolomite additives.

The general intelligence from the above experience seems to be that as temperature increases, fouling and bed agglomeration increases because of ash fusion. The temperature range at which this occurs is somewhere around $1400-1800^{\circ} \mathrm{F}\left(760-982^{\circ} \mathrm{C}\right)$, depending on the fuel. Changing the composition of the ash by adding lime or dolomite is beneficial, perhaps raising the fusion temperature by several hundred degrees $(F)$. No obvious solutions are presented for preventing the deposits that necessitated frequent cleaning by Hamrick and Ragland. Also, the high temperatures needed for the most efficient use of turbines may exceed the slagging prevention afforded by lime and dolomite: Wood is generally the cleanest biofuel and has a high ash fusion temperature. Field crops tend to have both higher ash and lower ash fusion temperatures.

\section{G. Past Attempts at Monitoring Alkali Transport in Gasification and Combustion Environments}

Because of the difficulty in sampling or monitoring alkali vapors, and because particulates are a large part of the final deposition problem, most work or alkali speciation has involved inferences from the collections of particulates and fume (aerosols) and their subsequent analysis as a function of size and conditions of formation. However, optical and mass spectroscopic techniques have been employed with some success.

\section{Particle Collection}

Particle and aerosol collection through water-cooled, isokinetic probes seems to be a well established art. In some cases, deposition within the probe was avoided by transpiring gas through a porous liner in the probe (Helble and Sarofim 1989). These workers used an Anderson Mark II cascade impactor with eight stages plus a preseparator for aerodynamic size classification of the particles $>0.3 \mu \mathrm{m}$. Particles $<0.3 \mu \mathrm{m}$ are collected in $0.2 \mu \mathrm{m}$ Fluoropore filters for weight and elemental analysis; deposited on transmission electron microscope grids in an ESP for microscopy studies; or introduced into a mobility classifier (TSI model 3071) for selective size classification of the submicrometer particles for subsequent elemental analysis (see Neville et al., 1983). Particle sizing can be done by TEM and automated image analysis.

Baxter et al. (1990) used rapid-quench helium probes to sample particles on membrane filters. The filters contain minimal $1 \mu \mathrm{m}$ openings and distinguish the residual particles from the submicron fume.

Scotto et al. (1988) used an aspirated, isokinetic, water-cooled probe to sample anywhere in their furnace. Samples were rapidly quenched by an adjustable free turbulent jet that diluted and cooled particles by $10^{6} \mathrm{~K} / \mathrm{s}$. This was followed by a cyclone and impactor size classifier. Gallagher et al. (1990) in this same laboratory passed particles from the probe through an 30lpm Anderson impactor outfitted with a preseparation cup, eight plates and an after filter to collect very small particles. On each impactor plate a 0.2 micron pore-size Millipore filter was thinly coated with mineral-free grease to minimize bounce off.

\section{Direct Total Alkali Detection}

Extractive and in-situ-techniques to measure individual or total alkali vapor species are in a much less developed stage. In fact a major portion of the experimental hot-gas cleanup effort at NREL is to develop and use direct, free-jet extractive techniques to interface with our molecular beam mass 
spectrometer. These techniques are discussed in part II. Optical and titrating techniques have been explored by several groups with limited success.

One of the principle developments in continuous alkali monitoring is that pioneered by the Ames Laboratory at Iowa State University (Hass and Eckels 1990). This system measures total alkali in the gas stream, both fume and vapor. The original Ames version, and two commercial prototypes developed by Idaho National Energy Laboratory (INEL), employ flame atomic emission spectrometry. The Morgantown version uses fiber-optics (FOAM-fiber optic alkali monitor-Hemsel et al. (1987). The basic principle of operation is the same for all of the alkali monitors mentioned above. A portion of the gas stream for which alkali concentration determinations are to be performed is introduced into a premixed propane-oxygen flame. There the sodium and potassium containing species are vaporized and the resulting sodium and potassium atoms are thermally excited. The concentrations of sodium and potassium present in the subject hot gas stream are determined by measuring the intensities of the characteristic atomic emission lines of the excited sodium and potassium atoms $(589 \mathrm{~nm}$ and $766.5 \mathrm{~nm}$, respectively).

The alkali monitors are calibrated by measurements of the emission intensities that are observed when known flow rates of hot surrogate sample gas streams containing known concentrations of sodium and potassium are introduced into the flame. Known concentrations of the elements are produced in the surrogate sample streams by nebulization of aqueous reference solutions containing known concentrations of sodium and potassium sulfates.

Argonne National Laboratory (ANL) has developed a batch-type total alkali detector using an activated-bauxite sorber bed technique (Lee and Carls 1989). Based on this technique, time-averaged concentration of $\mathrm{Na}+\mathrm{K}$ vapor of 1.3-1.5 ppmw were measured in pressurized fluid bed combustion (PFBC) of Beulah lignite, which is more than 1.5 orders of magnitude greater than currently suggested alkali specification limits. In testing the Ames-Morgantown FOAM system they documented appreciable capture of vapor-phase alkalis by the hot $\left(>850^{\circ} \mathrm{C}\right)$ stainless steel sampling line conducting the sample to the analyzer (Lee and Carls 1988, 1990). The most recent work on the regenerable, activated bauxite sorbent alkali monitor (RABSAM) by ANL is given by Lee and Swift (1991). This report shows a schematic application of an in-line RABSAM capsule in a PFBC exhaust duet. This arrangement essentially avoids sample lines, but limits sampling to batch averaged values.

Some of the monitoring developments and plans are detailed in a gas stream cleanup technology status report out of Morgantown (Bossert et al., 1990).

\section{In-situ Optical Vapor Detection}

Since 1983, Oldenborg and Baughcum (1987) and Oldenborg (1989) have been developing a laser-based diagnostic technique for direct monitoring of trace levels of gas-phase alkali components at the part per billion (ppb) level with compound specificity. Their approach is to use photo fragment fluorescence. In 1989 the technique looked promising for distinguishing $\mathrm{NaCl}, \mathrm{KCl}, \mathrm{NaOH}$, $\mathrm{KOH}$ and $\mathrm{Na}_{2} \mathrm{SO}_{4}$, depending on the relative concentrations in post-combustion coal gas streams. (An update on the status of this work is desirable because they had proposed work with PSI Technology Co. to do diagnostics in an actual post-flame combustion gas).

In 1987, Casleton et al. at Morgantown Energy Technology Center (METC) reported efforts to use laser induced fluorescence to measure concentrations of metal vapors such as $\mathrm{Ca}$ and $\mathrm{Mg}$. No results were given and the subsequent activities are not known. The technique of laser induced fluorescence 
(LIF) and laser induced dissociative fluorescence should be monitored for the applicability to biomass.

\section{Mass Spectroscopy}

Most of the previous mass spectroscopic (MS) combustion work has been aimed at coal alkali problems, but there is considerable variation in the level of physical simulation involved and in the sample introduction methods. All studies provide possible experimental alternatives and possible spectra for species that may be encountered in biomass work.

Hastie, Plante and Bonnell (1981), for example, have published results from transpiration mass spectrometry. In this technique gas is flowed slowly over a hot sample to saturate vapor in the gas which then exits from a small orifice into the mass spectrometer's ionizer. Their results indicate a potassium pressure of about $10 \mathrm{ppm}$ at $1027^{\circ} \mathrm{C}$ in the $\mathrm{K}_{2} \mathrm{O} / \mathrm{SiO}_{2}$ system, depending on the concentration of $\mathrm{K}_{2} \mathrm{O}$ in the system. Results for several other metal silicate systems are listed. Hastie, Zmbov, and Bonnell (1984) also present detailed results from transpiration mass spectrometric analysis of the $\mathrm{KCl}$ and $\mathrm{KOH}$ systems. Temperature dependence of the monomer-to-dimer ratios are reported as is the variation of fragmentation patterns as a function of temperature. Thermodynamic data for the $\mathrm{KOH}$ and $\mathrm{KCl}$ systems are evaluated. A similar, more standard technique is Knudsen effusion mass spectrometry in which flowing gas is not used. Seeding salt and sulfur trioxide into a methane/oxygen flame has shown that sodium sulfate can be formed in a flame (Stearns 1977). A compilation of many species that have been observed in seeded flames is available (Stearns 1979).

Knudsen effusion work on low-temperature-ashed coal has yielded interesting results (Brittain 1988). Ash was used to avoid obscuration of weak signals by the organic fraction in the coal. Both a quadrupole and a high resolution sector instrument were used to identify ionization and measure pressures. Pressures were calculated from tabulated ionization cross sections and instrument calibration with silver. Very little was seen below $700^{\circ} \mathrm{C}$. In vacuum, the major species were the free metal form of potassium and sodium with significant amounts of the thio-borates $\mathrm{KBS}_{2}$ and $\mathrm{NaBS}_{2}$ as well as $\mathrm{NaCl}$ and $\mathrm{KCl}$. In the presence of $10^{-5}$ atm of oxygen, alkali vaporization was suppressed up to about $927^{\circ} \mathrm{C}$ at which point the major species were the borates $\mathrm{LiBO}_{2}, \mathrm{KBO}_{2}$ and $\mathrm{NaBO}_{2}$ as well as $\mathrm{NaCl}$. Low levels of boron in borate or organic borate form (Marschner 1986) are present in biomass and may be of importance in alkali emission.

Results of studies of a coal/air flame (Greene and O'Donnell 1987) are instructive as to the forms of alkali and the changes that may occur during combustion. This MBMS system was calibrated with a gas mixture of helium, neon, argon, krypton, and xenon in nitrogen and by nebulizing salt solutions into the flame. The studies were done primarily on a single standard lean flame because of the difficulty in obtaining a range of stable lean flame. The coal analyses shown gave 4-6\% ash, $1 \%$ sulfur, $0.3-0.6 \%$ sodium, and $0.3-0.4 \%$ silicon by weight. Major species seen were $\mathrm{SO}_{2}$, $\mathrm{NaOH}$, and $\mathrm{HCl}$. The intriguing feature was a "spike" of sodium signal, presumably from free metal, variously reported as $400-600 \mathrm{ppm}$ in the figures and $200-300 \mathrm{ppm}$ in the text. This occurred at 3-5 $\mathrm{mm}$ from the burner with a burner flame speed of $50-60 \mathrm{~cm} / \mathrm{sec}$ so its duration is only about 5-m sec. In one run it was apparent that the other more slowly-growing sodium signals could not account for the sodium that disappeared as the spike decayed away, so the sodium must have been incorporated into some particulate, perhaps the oxide. They were also able to reduce the sodium evolution by more than an order of magnitude by ion-exchanging the sodium out of the coal.

In related work, some fairly similar results were seen (Greene et al., 1988). Their apparatus involved heating air or similar fluids at 5-10 atm pressure and $10 \mathrm{ft} / \mathrm{sec}$ to $2000^{\circ} \mathrm{F},\left(1093^{\circ} \mathrm{C}\right)$. Large $(4 \mathrm{~mm})$ coal particles were mounted in the fluid near the MBMS orifice and the evolution of species was 
observed. When a series of particles of the same coal was burned at different distances from the orifice at $5 \mathrm{~atm}$ pressure of air at $2000^{\circ} \mathrm{F}$, a first order decay constant for sodium metal of $315 \mathrm{~s}^{-1}$ was found. In $95 \%$ nitrogen, 5\%oxygen this was reduced to $161 \mathrm{~s}^{-1}$. When observed as a function of time at fixed distance for a variety of coals, the sodium and $\mathrm{SO}_{2}$ signals rise and fall sharply during the first several seconds of burning, while $\mathrm{CO}$ and other combustion products continue for a minute or two. One coal showed a tail to the sodium evolution which may indicate sodium bound in different forms. The major species was again sodium metal in the hundreds to thousands of ppm range. Sodium evolution was orders of magnitude lower (frequently not detected) at $1600^{\circ} \mathrm{F}\left(871^{\circ} \mathrm{C}\right)$ than at $2250^{\circ} \mathrm{F}\left(1232^{\circ} \mathrm{C}\right)$. It was also greatly suppressed in simulated gasifier effluent containing a mixture of $\mathrm{CO}, \mathrm{CO}_{2}, \mathrm{H}_{2}, \mathrm{H}_{2} \mathrm{O}, \mathrm{N}_{2}$ at calculated equilibrium levels for a 2:1:1 coal:air:steam feed.

One other coal system of note is the laboratory fluidized bed combustor with MBMS used by Krishnan et. al (1991). Through careful calibration using noble gas mixtures and vaporized salts, detection of alkali down to $0.05 \mathrm{ppm}$ was claimed. However, in the presence of air from 800 to $950^{\circ} \mathrm{C}$, the levels of $\mathrm{Na}, \mathrm{Na}_{2} \mathrm{O}, \mathrm{NaCl}$ and $\mathrm{Na}_{2} \mathrm{SO}_{4}$ were less than or equal to $0.05 \mathrm{ppm}$ and nearly $100 \%$ of the $\mathrm{Na}$ was accounted for in either bed ash or fly ash. Fine fly ash, with less than $10 \mu \mathrm{m}$ diameter was enriched in sodium, some particles may have contained $30 \%$ sodium compounds. Sodium in fine fly ash from Beulah Zap lignite was mainly sodium sulfate.

In summary, the MS work on coal has shown that from coal and ash, or ash-like materials, alkali metal vapors can be measured. From coal itself it is generally sodium metal that is the dominant species when measured close to the coal surface, but this decays away rapidly as, apparently, oxide or sulfate or some other low-vapor-pressure species is formed. Borate and thio-borate species may also be significant. The levels of vapor species are very low, probably within turbine specifications at about $800^{\circ} \mathrm{C}$ or lower, but far in excess of them at about $1200^{\circ} \mathrm{C}$.

The next question is, of course, "Will biomass behave like coal." The range of ash levels available in coal is similar to that in biomass but coal is expected to have more mineral matter than biomass. Also, the oxygen content of coal is much lower and the mechanical properties of coal are much different. If, however, the ion-exchangeable sodium that seemed dominant in one coal study mentioned above is actually sodium bound by carboxyl groups to the coal, this may behave very much like organically bound metals in biomass. However, because the potassium is mostly in water solution which will form some salt when the biomass dries, it may behave more like salt vaporization studies than like the mineral portion of coal. 


\section{Part II}

\section{The NREL Direct Sampling System and Screening Results for Alkali Vapor Species Release During the Combustion of Herbaceous and Woody Species}

As has been documented in Part I, the transport of alkali has posed substantial problems that both boiler and turbine operators have had to work around. As turbines are pushed to higher temperatures, these problems are expected to become more severe. However, not all alkali species are of equal importance. Dry powders greater than $10 \mu \mathrm{m}$ can be adequately controlled by cyclones and filters. Very fine particulates of certain silicates, for example, may pass through the turbine without sticking or evaporating appreciably. Liquid droplets or gases that react to form corrosive liquids, however, may cause severe slagging and corrosion. It is not possible to predict the form of alkali that will be transported through a particular power-plant process given the current knowledge of biomass composition, structure and combustion dynamics. Therefore, work has been undertaken to measure the alkali species formed in the combustion and gasification of biomass materials with the initial focus on the release of gas phase alkali. This information will guide the selection of process conditions and hot-gas-cleanup methods, and be used to determine predictive correlations between ultimate analyses of biomass and fouling behavior.

\section{A. Experimental Apparatus}

An alkali species release during the combustion of 20-35mg samples of selected biomass was monitored and studied using direct-sampling molecular beam mass spectrometry. The molecular beam sampling/mass spectrometric technique is well-suited to studying alkali species in combustion gases because these reactive and condensible species are effectively quenched and preserved during the expansion. The non-equilibrium nature of the free jet expansion and the subsequent formation of a molecular beam inhibits the condensation of alkali species at temperatures well below their condensation point. Comprehensive detection of all gas phase species of interest is possible using the mass spectrometer and facilities for pattern matching and tandem MS are available to aid in deciphering complex mass spectra. The molecular beam/mass spectrometer system constructed and operated at the National Renewable Energy Laboratory has been described in the literature (Soltys and Milne 1982; Milne and Soltys 1983; Evans and Milne 1987 a,b) so only the salient points will be discussed in relation to the present study.

The following biomass samples were used in the present study: switchgrass, corn stover, eucalyptus, poplar, planer shavings of lodgepole pine, wheat straw and rice straw. Except for the wheat straw and the rice straw, the samples were ground in a mill to $+40 /-60$ mesh. The wheat straw and rice straw samples were more finely ground. A description of the biomass samples, along with the proximate and ultimate analyses for each sample, is given in Appendix A. The biomass samples were combusted in a tubular quartz reactor (18 mm O.D. and $16 \mathrm{~mm}$ I.D.) that was placed into a standard two zone electric clam-shell furnace as depicted in Figure 8. The heated zone in the furnace was $30 \mathrm{~cm}$ long. For the experiments discussed below, the furnace temperature was set at either $1373 \mathrm{~K}$ or $1073 \mathrm{~K}$. Biomass samples were loaded into hemi-capsular quartz boats of such a size that approximately $30 \mathrm{mg}$ of ground, loosely packed, biomass material filled the boat. The boats were then placed on the end of a $6 \mathrm{~mm}$ diameter ( $\left.0.25^{\prime \prime}\right)$ piece of stainless steel tubing that was inserted into the furnace through a $18 \mathrm{~mm}\left(0.75^{\prime \prime}\right)$ Swagelock tee. A type-K (chromel-alumel) thermocouple with a $0.5 \mathrm{~mm}(0.020$ ") diameter inconel sheath was inserted through the stainless steel tubing such that the junction was close to the edge of the sample boat. The actual boat temperature and flame temperature were not measured, however, the temperature in the vicinity of the sampling boat could be monitored. A mixture of helium and oxygen (5\% or 20\%) flowed through the reactor from back to front at a total gas flow rate of 4.5 standard liters per minute. Under these conditions the combustion gases have a residence time of about 0.05 seconds in the reactor before reaching the sampling orifice. For several of the experiments, steam was added to the atmosphere 


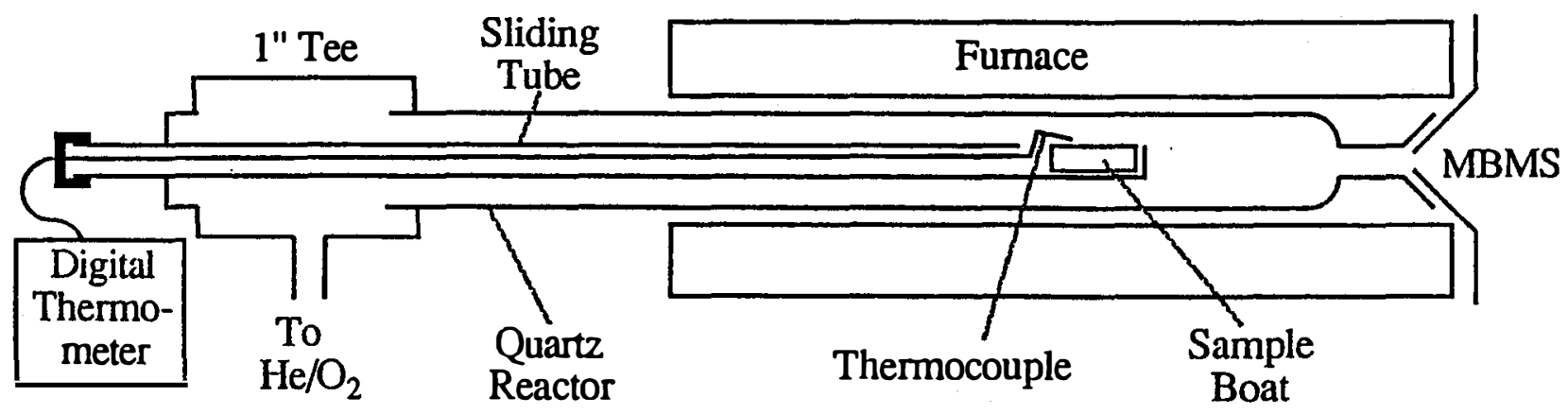

Figure 8. A schematic representation of the quartz tube reactor used in the alkali studies.

inside the reactor. Steam was produced by injecting water into the rear of the furnace through a needle fed by a syringe pump. Stainless steel shot was packed around the tip of the needle to increase the surface area for evaporation of water. This provides a steady flow of 8-15\% steam by volume. The end of the reactor was fitted around the tip of a conical orifice used to sample the combustion gases.

The molecular beam sampling orifice used was a stainless steel cone, $25 \mathrm{~mm}$ high with a $90^{\circ}$ interior angle and an orifice diameter of $200 \mu \mathrm{m}$. The sampling orifice was inserted into the furnace to keep it hot and thus prevent condensation on the sampling cone. The actual temperature of the orifice was not measured, however, when the furnace temperature was set at $1373 \mathrm{~K}$ the tip of the orifice glowed orange. The sampled volume of gas expanded supersonically through the orifice into the first stage of the differentially pumped vacuum system illustrated in Figure 9. The expanded gases were skimmed by a conical skimmer at the entrance to the second stage of the vacuum system forming a molecular beam that was directed into the ionization region of the mass spectrometer in the third stage of the vacuum system. Ions were formed by electron impact ionization of the sampled gases with a nominal electron energy of $25 \mathrm{eV}$. The ions were filtered by the quadrupole and detected with an off axis electron multiplier. A Teknivent Vector Two computer and software package were used to control the scanning parameters of the mass spectrometer and collect the pre-amplified electron multiplier signal as a function of time. The mass spectrometer was scanned continuously at a rate of approximately $100 \mathrm{amu} / \mathrm{sec}$. A complete mass spectrum was recorded approximately once every 1.5 seconds. A typical experimental run consisted of loading the quartz boat containing the sample into the cooler end of the reactor and waiting for a short time to pass for air to be flushed from the system. The data collection was then initiated to record a background spectrum for 18-30 seconds. The sample was then inserted into the furnace as quickly as possible (typically 6 to 9 seconds). Combustion occurred almost immediately after the sample was inserted, however, data were collected for at least an additional minute to encompass the combustion (or devolatilization) phase, the char burning phase and the ash "cooking" phase. Background subtraction from 


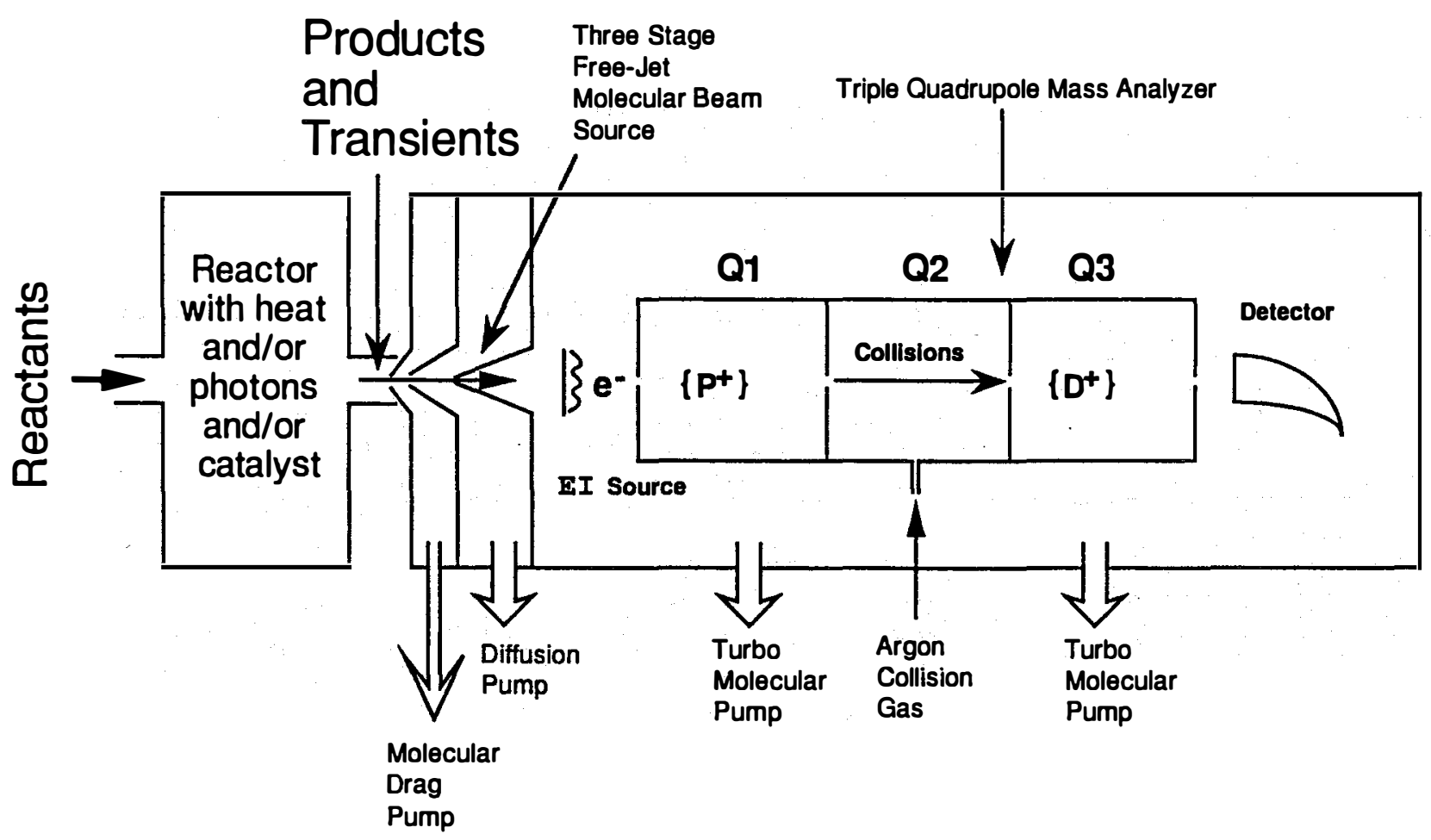

Figure 9. A schematic of the molecular beam mass spectrometric sampling system used to monitor the combustion of biomass.

the total ion signal yielded corresponding mass spectra at a given time during the combustion event or averaged over a given phase of the combustion event.

\section{B. Experimental Results}

\section{Screening the Biomass Feedstocks}

The seven biomass feedstocks previously listed were subjected to combustion in a $20 \%$ oxygen in helium atmosphere at $1373 \mathrm{~K}$ to investigate the release of alkali during combustion and identify these alkali species. Under these conditions, the large excess of oxygen assured complete combustion and the furnace temperature was high enough to insure the volatilization of alkali species. These screening experiments consisted of using multiple samples of each biomass feedstock. Dilute solutions of alkali salts were used as calibration standards as discussed below and empty quartz boats were used as blanks. The samples were studied in a pseudo-random order to factor out any systematic instrument response variations and to provide a statistically valid data set. The calibration standards were made by pipetting 50 or $100 \mu \mathrm{l}$ of an alkali salt solution into the quartz boat and allowing the water to evaporate at room temperature. This provided microgram quantities of the alkali salt of interest in the boat. Complete vaporization of the salt was assumed when the sample was inserted into the furnace. In this way, the mass spectrometer signals for the alkali species of interest were calibrated.

As mentioned above, the combustion of the biomass samples appeared to occur in three separate phases. These phases are distinguished in Figure 10 which shows the total ion intensity as a function of time for combustion of a switchgrass sample in a $20 \% \mathrm{O}_{2}$ in helium at $1373 \mathrm{~K}$. During the combustion or devolatilization phase in Figure $11 \mathrm{a}, \mathrm{CO}_{2}$ (monitored at mass 45 to prevent overload) 


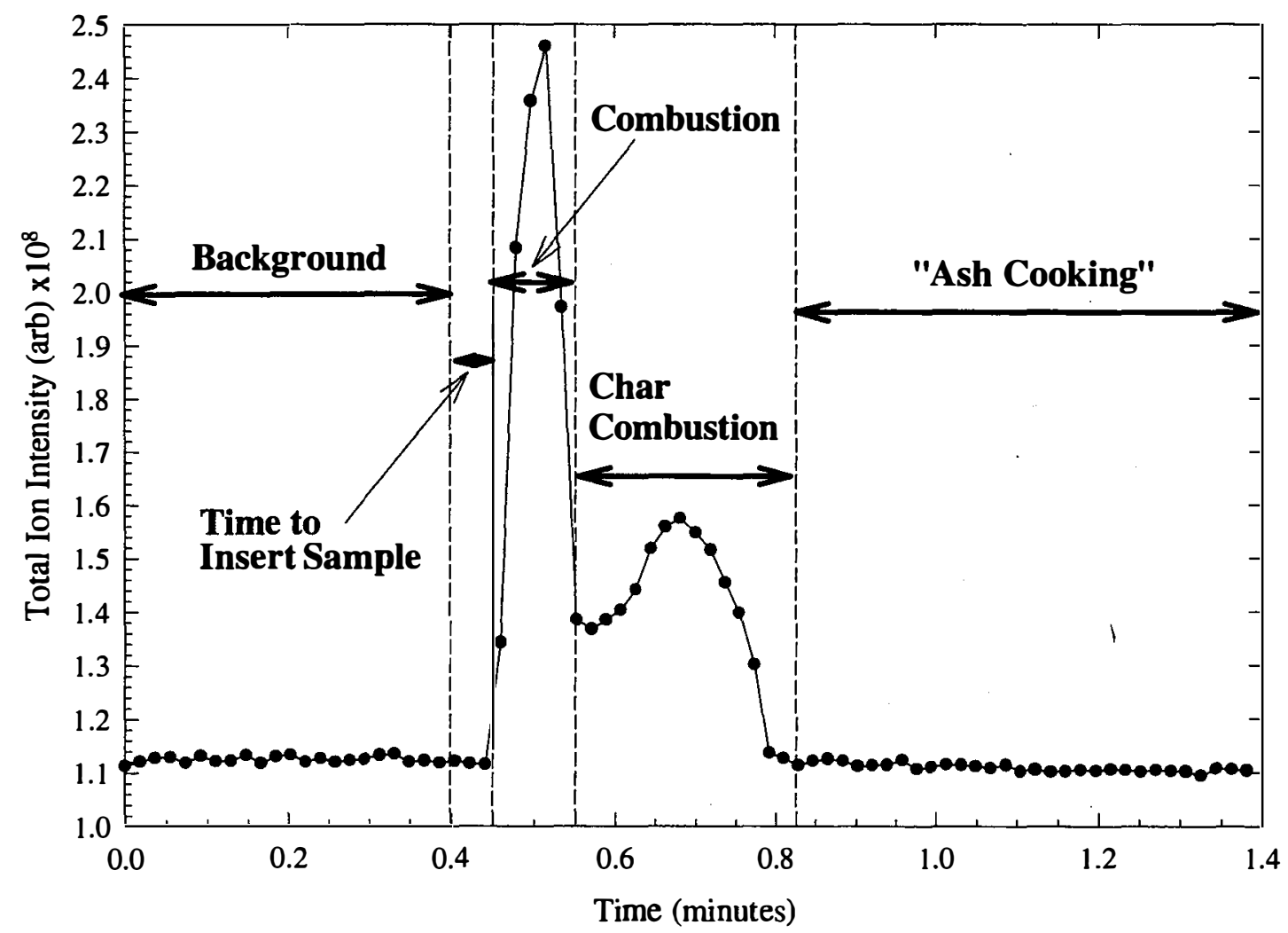

Figure 10. A plot of the total ion intensity versus time recorded during the combustion of switchgrass at $1373 \mathrm{~K}$ in a flowing $20 \% \mathrm{O}_{2}$ in helium atmosphere.

and $\mathrm{H}_{2} \mathrm{O}$ are formed while $\mathrm{O}_{2}$ is consumed. Some $\mathrm{CO}, \mathrm{NO}$ and $\mathrm{SO}_{2}$ are produced and, depending on the feedstock, $\mathrm{HCl}$ is also liberated during this phase. There is also a large fraction of organic hydrocarbons liberated during the combustion phase. The intensity and fragmentation of these species produces a rich mass spectrum making it difficult to identify minor species such as alkalies. The organic species are liberated by the time the char combustion phase begins (see Figure 11b) resulting in a much less congested mass spectrum. As a result, it is convenient to study alkali release and speciation during the char combustion phase. In addition, more $\mathrm{CO}$ is produced and $\mathrm{SO}_{2}$ is also liberated in this phase. By the end of the char combustion phase, most of the volatile species have been released. As a result, during the ash "cooking" phase (Figure 11c), not much is detected. The time evolution of several of the major and minor combustion species are illustrated in Figure 12 which shows the intensity versus time profiles for several ions detected during the combustion of switchgrass at $1373 \mathrm{~K}$ in $\mathrm{He} / \mathrm{O}_{2}(20 \%)$. Time zero in these plots is at approximately 0.35 minutes, when the sample was inserted into the furnace. The initial combustion phase is completed in approximately 0.1 minutes ( 6 seconds) as observed by the formation of $\mathrm{CO}_{2}$ and $\mathrm{H}_{2} \mathrm{O}$ during the consumption of $\mathrm{O}_{2}$. Water and $\mathrm{CO}$ are also formed during the char combustion phase from 0.55 to 0.85 minutes. The next plot shows that $\mathrm{NO}$ and $\mathrm{SO}_{2}$ are predominantly formed during the combustion phase, however, these species are also liberated during the char combustion phase. In the third plot, $\mathrm{HCl}$ is observed to be released primarily during the combustion phase and the potassium species $\mathrm{K}^{+}$and $\mathrm{KCl}^{+}$are released during the char combustion phase. Examining all three plots indicates that the overall ion intensity detected during the ash "cooking" phase is small.

The char combustion phase appears to contain the most valuable information for studying alkali release during biomass combustion. Figures 13-19 display the mass spectra averaged over the char combustion phase during the combustion of the seven listed biomass feedstocks. The ion intensities 


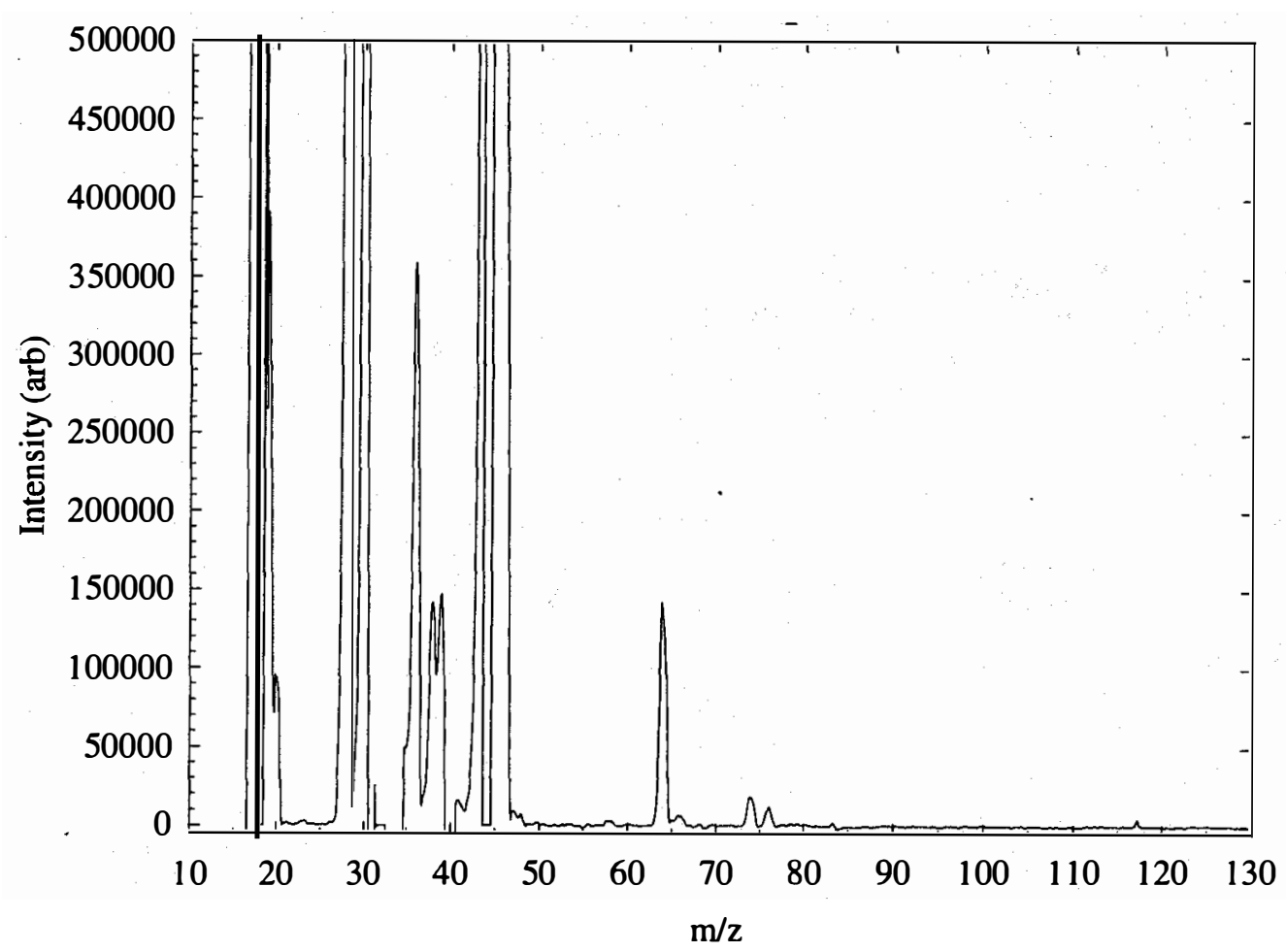

Figure 11a. Average mass spectra recorded during the individual phases of switchgrass combustion at $1373 \mathrm{~K}$ in a flowing $20 \% \mathrm{O}_{2}$ in helium atmosphere. a) The combustion or devolatilization phase. The spectra are normalized to the background ${ }^{\mathrm{s}} \mathrm{O}_{2}$ signal intensity such that relative absolute intensities are semi-quantitative. The compositions listed are from the ultimate analysis of the feedstock "as received."

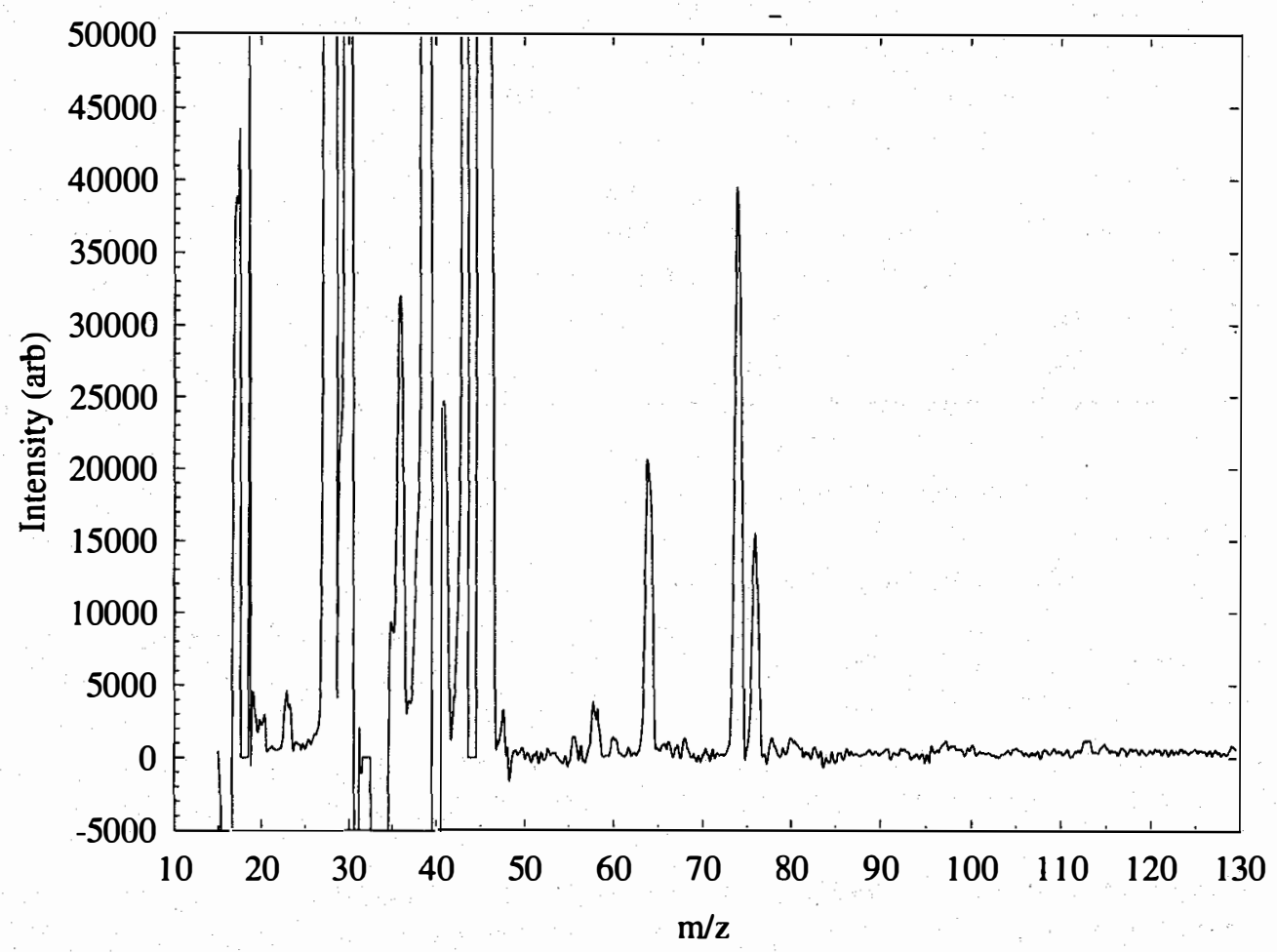

Figure 11b. The char combustion phase 
TP-5597

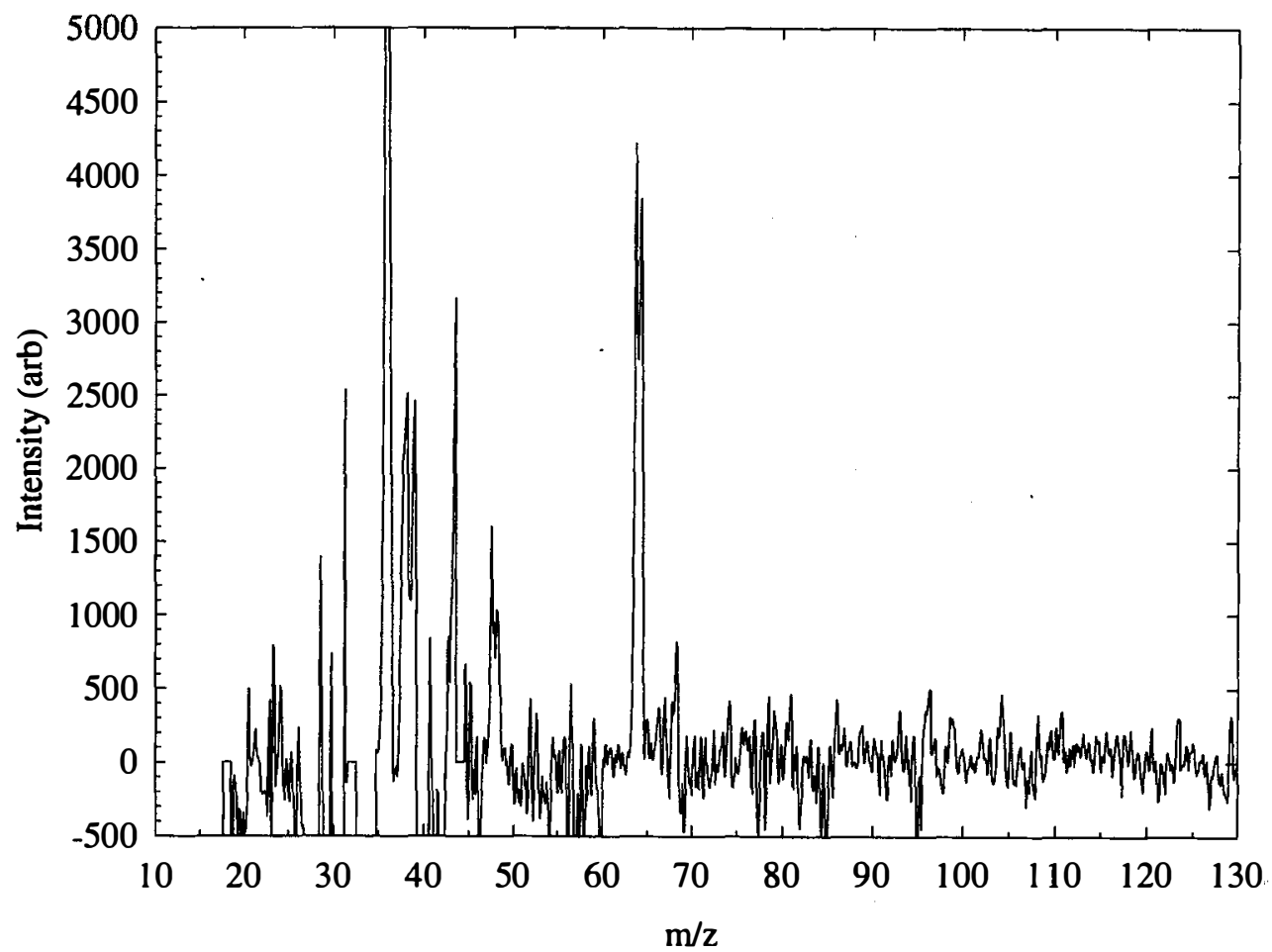

Figure 11c. The ash "cooking" phase
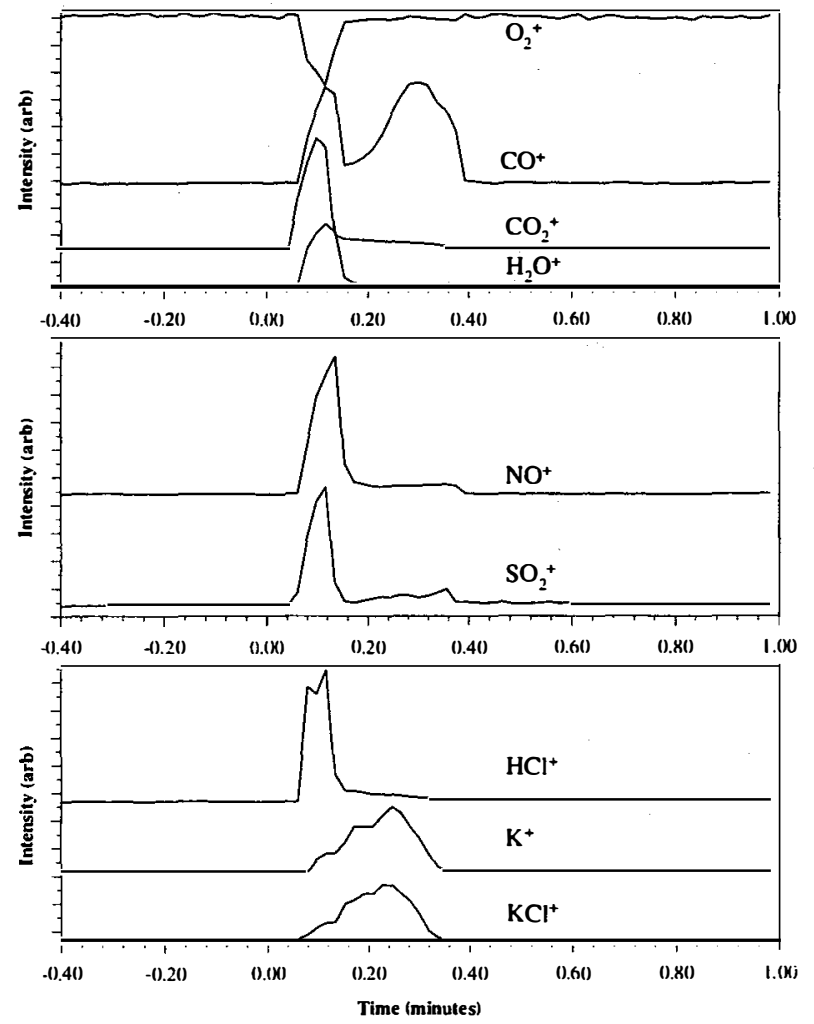

Figure 12. Time evolution of major organic and inorganic vapor species in the batch combustion of switchgrass at $1100^{\circ} \mathrm{C}$ in flowing $\mathrm{He-20} \% \mathrm{O}_{2}$ Relative intensities should not be compared. 


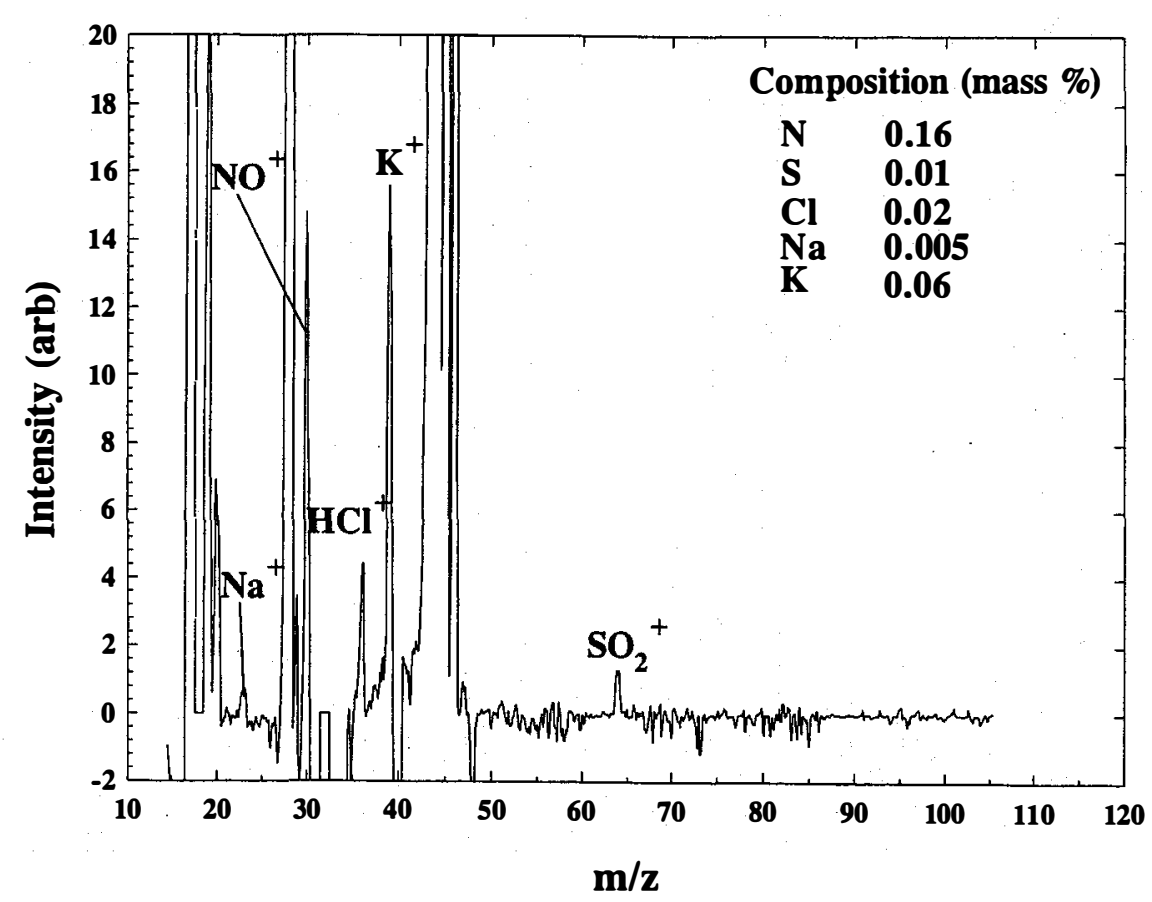

Figure 13. Mass spectrum (normalized to the background ${ }^{34} \mathrm{O}_{2}$ signal intensity) recorded during the char combustion phase of Planer Shavings of lodgepole pine batch combustion at $1373 \mathrm{~K}$ in a flowing $20 \% \mathrm{O}_{2}$ in helium atmosphere. The composition listed in the inset is from the ultimate analysis of the feedstock "as received."

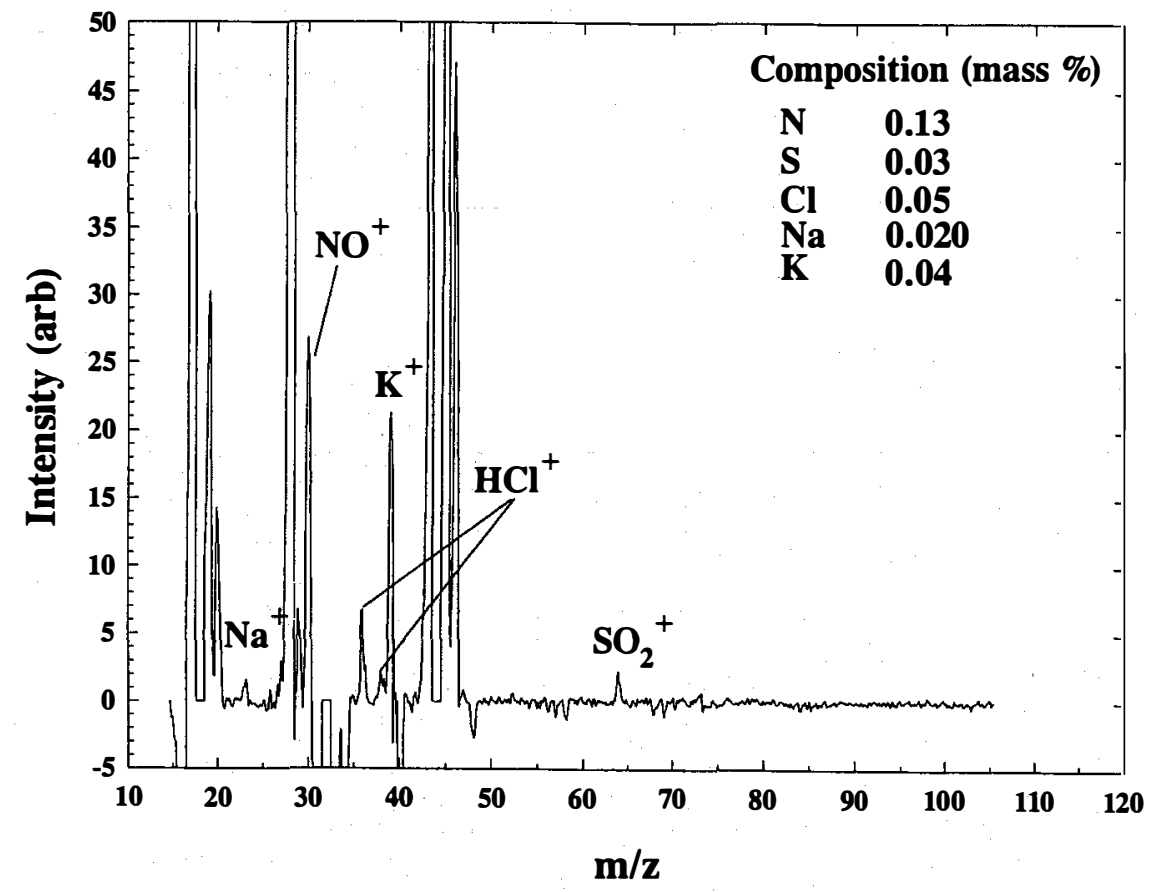

Figure 14. Mass spectrum (normalized to the background ${ }^{34} \mathrm{O}_{2}$ signal intensity) recorded during the char combustion phase of Eucalyptus batch combustion at $1373 \mathrm{~K}$ in a flowing $20 \% \mathrm{O}_{2}$ in helium atmosphere. The composition listed in the inset is from the ultimate analysis of the feedstock "as received." 
TP-5597

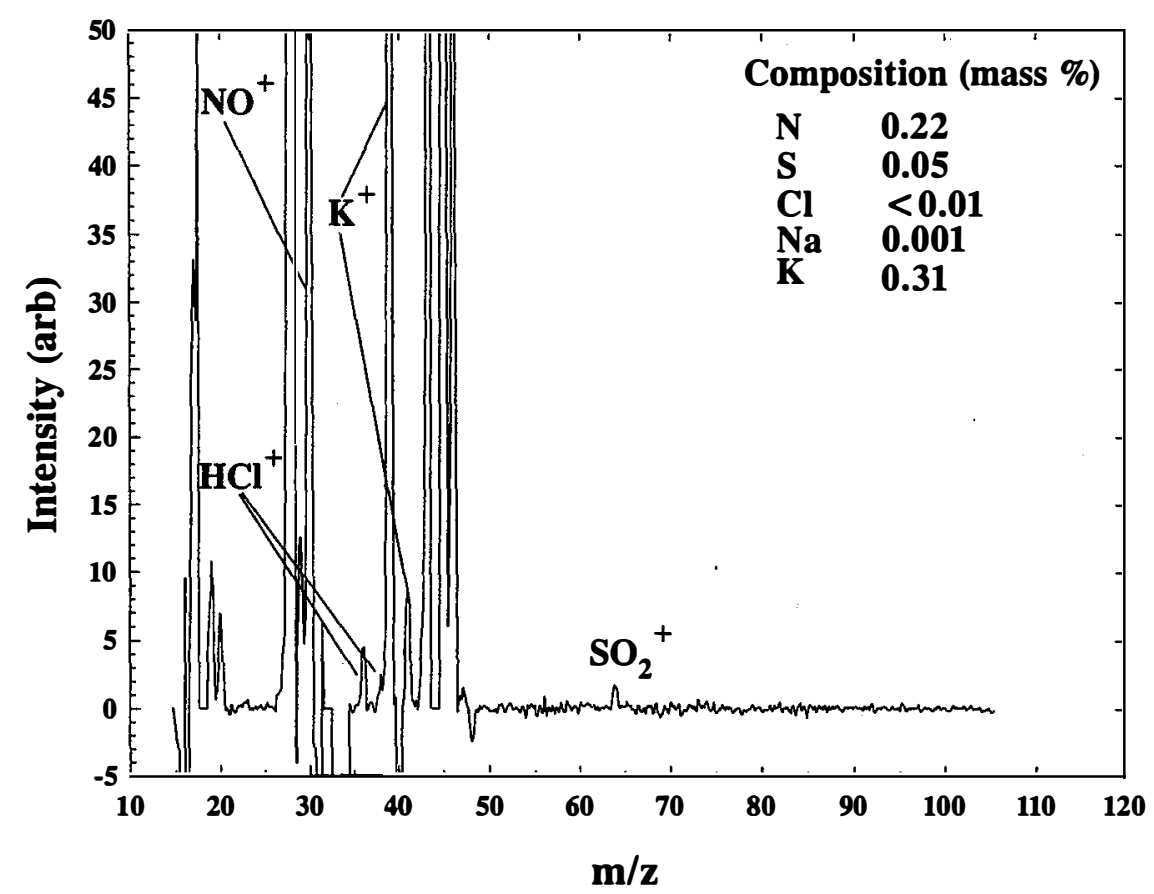

Figure 15. Mass spectrum (normalized to the background ${ }^{34} \mathrm{O}_{2}$ signal intensity) recorded during the char combustion phase of Poplar batch combustion at $1373 \mathrm{~K}$ in a flowing $20 \% \mathrm{O}_{2}$ in helium atmosphere. The composition listed in the inset is from the ultimate analysis of the feedstock "as received."

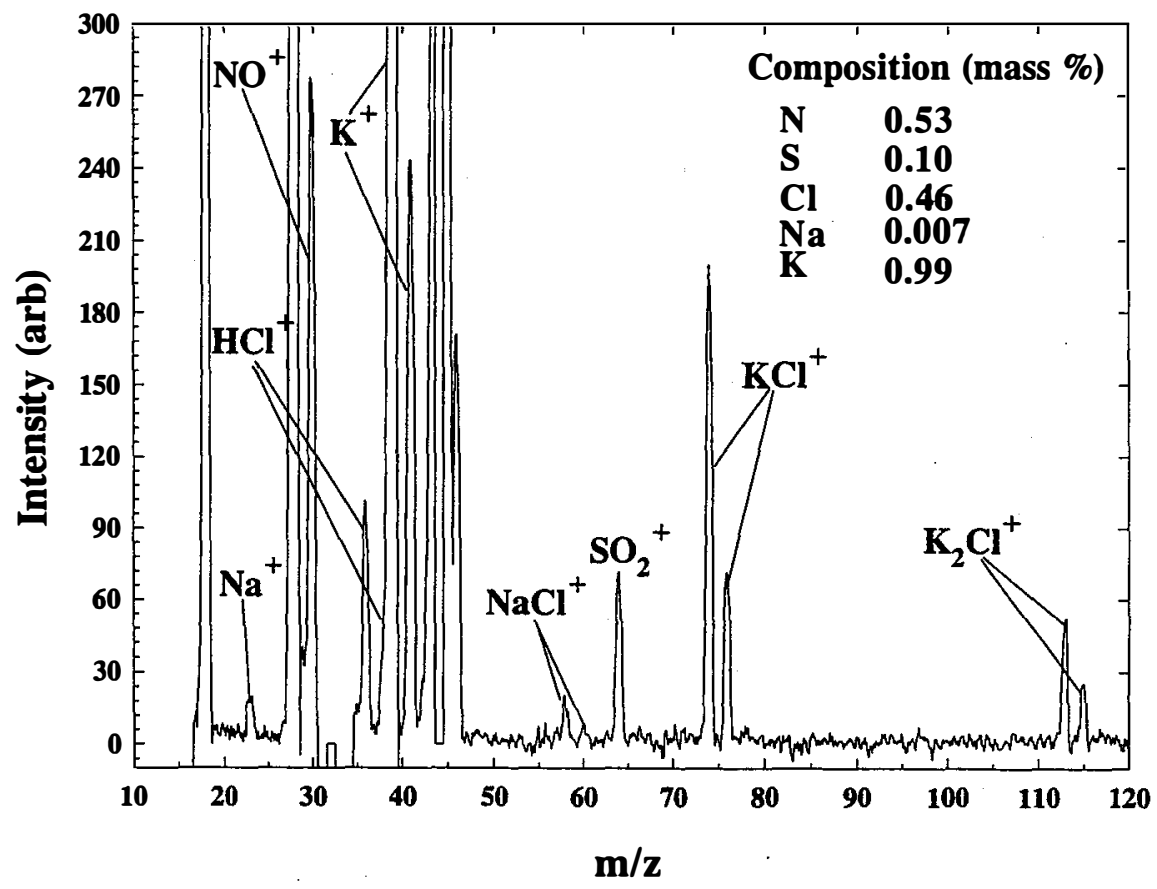

Figure 16. Mass spectrum (normalized to the background ${ }^{34} \mathrm{O}_{2}$ signal intensity) recorded during the char combustion phase of Switchgrass batch combustion at $1373 \mathrm{~K}$ in a flowing $20 \% \mathrm{O}_{2}$ in helium atmosphere. The composition listed in the inset is from the ultimate analysis of the feedstock "as received." 


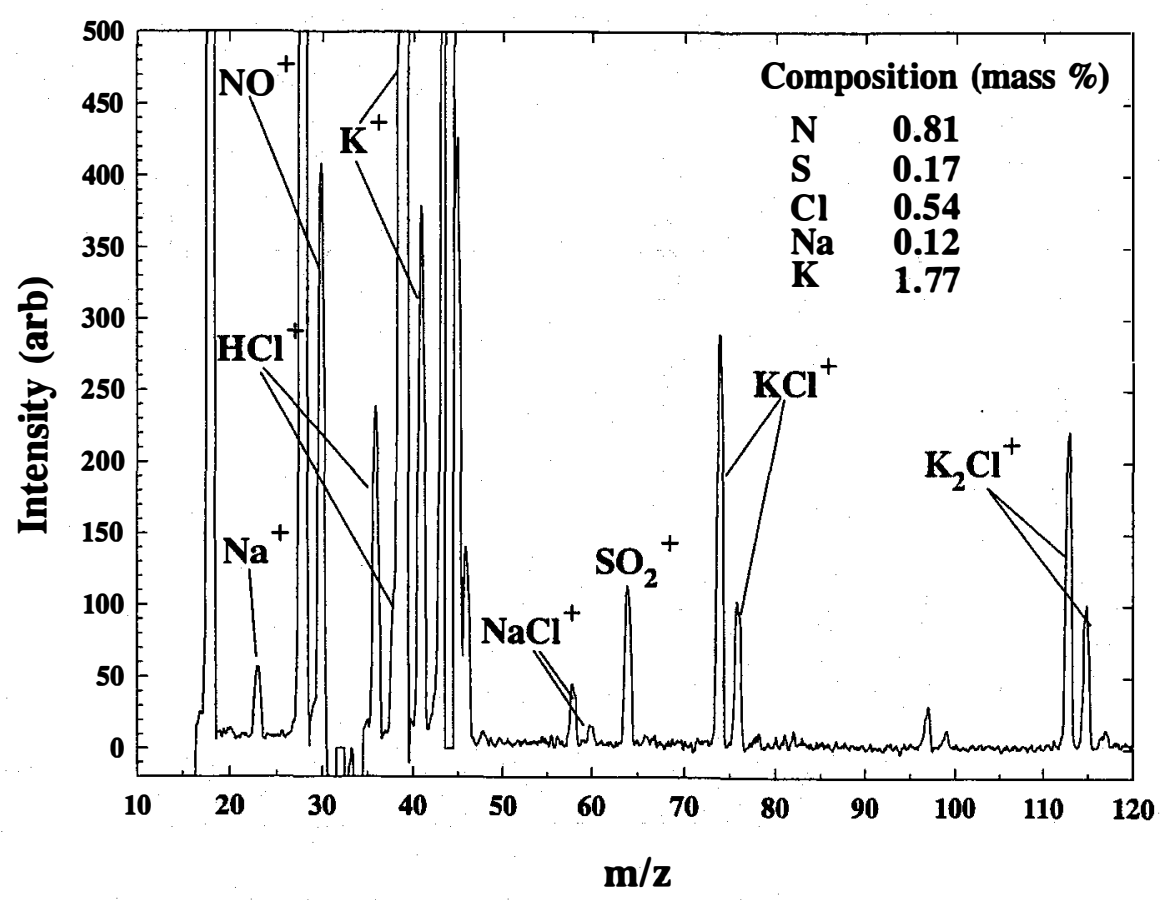

Figure 17. Mass spectrum (normalized to the background ${ }^{34} \mathrm{O}_{2}$ signal intensity) recorded during the char combustion phase of Rice Straw batch combustion at $1373 \mathrm{~K}$ in a flowing $20 \% \mathrm{O}_{2}$ in helium atmosphere. The composition listed in the inset is from the ultimate analysis of the feedstock "as received."

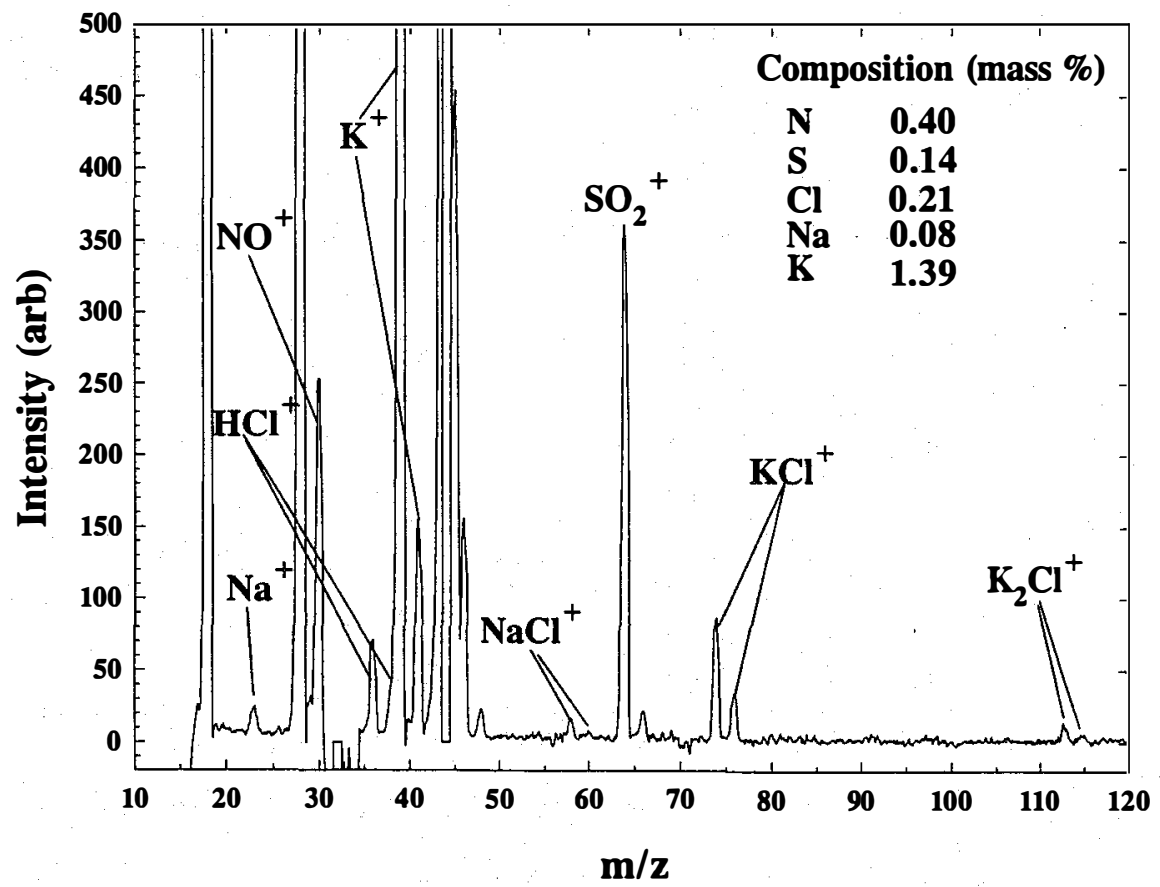

Figure 18. Mass spectrum (normalized to the background ${ }^{34} \mathrm{O}_{2}$ signal intensity) recorded during the char combustion phase of Wheat Straw batch combustion at $1373 \mathrm{~K}$ in a flowing $20 \% \mathrm{O}_{2}$ in helium atmosphere. The composition listed in the inset is from the ultimate analysis of the feedstock "as received." 


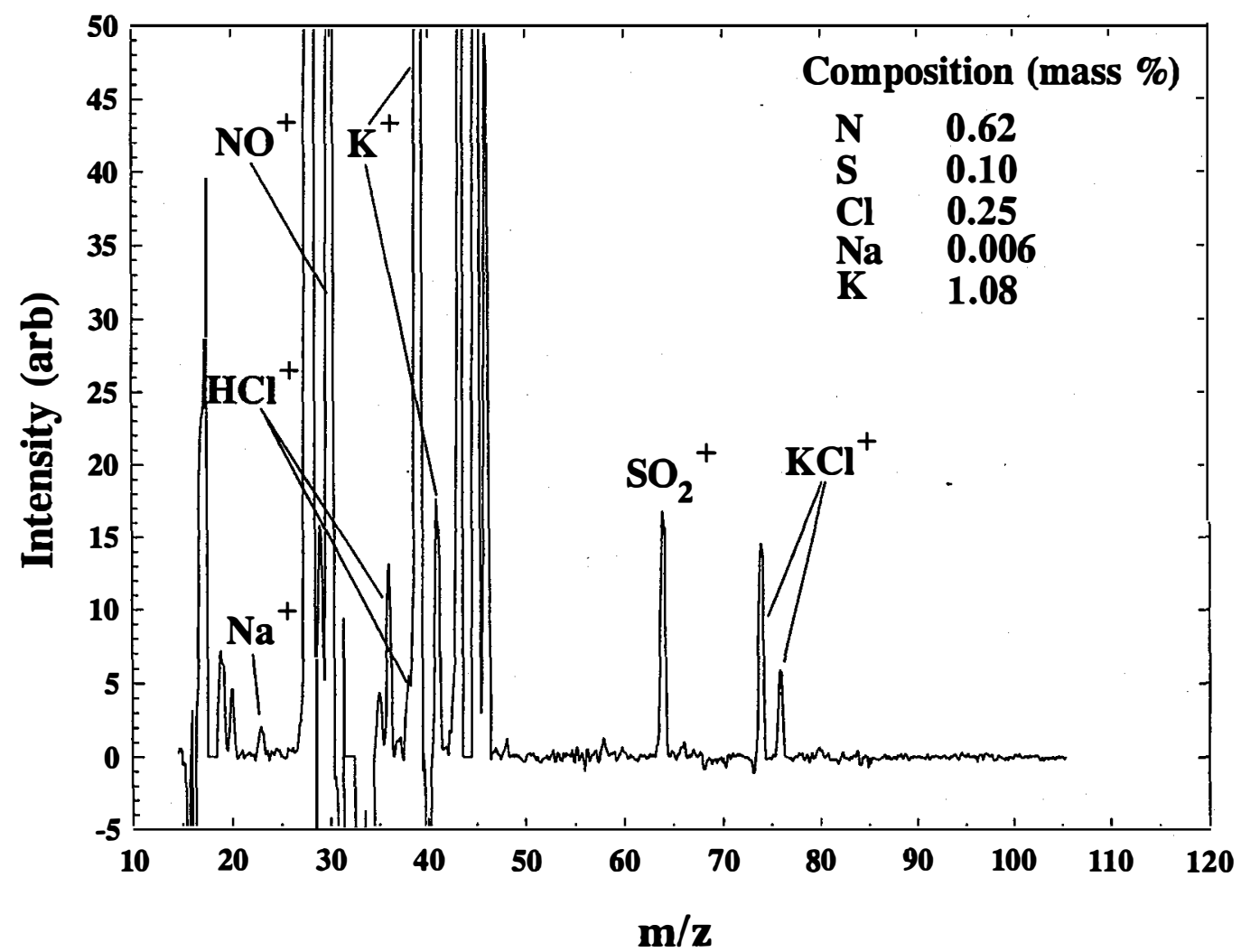

Figure 19. Mass spectrum (normalized to the background ${ }^{34} \mathrm{O}_{2}$ signal intensity) recorded during the char combustion phase of Corn Stover batch combustion at $1373 \mathrm{~K}$ in a flowing $20 \% \mathrm{O}_{2}$ in helium atmosphere. The composition listed in the inset is from the ultimate analysis of the feedstock "as received."

have all been normalized to the background ${ }^{34} \mathrm{O}_{2}^{+}$signal intensity, that is assumed constant during the char combustion phase (see Figure 12). As a result, the relative intensities of the ion signals in Figures 13-19 are semi-quantitative and it is valid to compare relative ion intensities between spectra. Uncertainties of a factor of two could be caused by differences in mass spectrometer tuning from day to day and varying intervals of spectral averaging. (Note: as the discussion progresses, it will appear that the absolute intensity of the corn stover char phase spectrum in Figure 19 is in error, and that it is in fact not as intense as it should be. This discrepancy has been checked and confirmed, however, at this time it can not be explained. Further work will be done to resolve this issue.) The compositions tabulated in the insets are the results of the ultimates analyses for the feedstock of interest as received (not dried). These feedstocks can be divided into two separate groups, woody trees and short rotation herbaceous crops, that have very different characteristics. For the most part, the wood samples, planer shavings of lodgepole pine, poplar and eucalyptus, have a very low chlorine content and a low alkali content as indicated in the compositions shown in the insets of Figures 13-15. This is also observed in the mass spectra recorded during the char phase combustion of each of these feedstocks. For example, the char phase mass spectra of the planer shavings sample exhibits a large ion intensity at masses 44,45 and 46 which are the isotopes of $\mathrm{CO}_{2}$. The peak at $28 \mathrm{amu}$, corresponding to $\mathrm{CO}^{+}$is also large. In contrast, the peaks at 30 and $64 \mathrm{amu}$, corresponding to $\mathrm{NO}^{+}$and $\mathrm{SO}_{2}{ }^{+}$, respectively are considerably weaker. The $\mathrm{HCl}^{+}$peaks at 36 and $38 \mathrm{amu}$ are also small. There is some evidence of alkali release because $\mathrm{K}^{+}$is observed at $39 \mathrm{amu}$ and $\mathrm{Na}^{+}$is observed at 23 amu. At the present time, it is not possible to determine whether these alkalis are liberated as free $\mathrm{K}$ and $\mathrm{Na}$ or whether they are fragment ions from some other parent alkali species. 
recorded during the char phase combustion of each of these feedstocks. For example, the char phase mass spectra of the planer shavings sample exhibits a large ion intensity at masses 44,45 and 46 which are the isotopes of $\mathrm{CO}_{2}$. The peak at $28 \mathrm{amu}$, corresponding to $\mathrm{CO}^{+}$is also large. In contrast, the peaks at 30 and $64 \mathrm{amu}$, corresponding to $\mathrm{NO}^{+}$and $\mathrm{SO}_{2}{ }^{+}$, respectively are considerably weaker. The $\mathrm{HCl}^{+}$peaks at 36 and $38 \mathrm{amu}$ are also small. There is some evidence of alkali release because $\mathrm{K}^{+}$is observed at $39 \mathrm{amu}$ and $\mathrm{Na}^{+}$is observed at $23 \mathrm{amu}$. At the present time, it is not possible to determine whether these alkalis are liberated as free $\mathrm{K}$ and $\mathrm{Na}$ or whether they are fragment ions from some other parent alkali species. Similar trends are observed in the char phase mass spectrum of eucalyptus. According to the poplar analysis, there is an order of magnitude more potassium and less sodium in this sample than in the planer shavings and eucalyptus. This is reflected in the char phase mass spectrum of poplar that displays a very intense $\mathrm{K}^{+}$peak at 39 amu. In fact the potassium isotope at 41 amu (6.7\% natural abundance (Weast, 1985)) is also observed.

In contrast, the herbaceous feedstocks (switchgrass, rice straw, wheat straw and corn stover) have a very high chlorine and alkali content. There is also a higher percentage of sulfur and bound nitrogen in these species. This is indicated by the comparatively rich char phase mass spectra recorded for these species. The char phase mass spectrum for switchgrass combustion shown in Figure 16 exhibits large signals resulting from $\mathrm{CO}$ and $\mathrm{CO}_{2}$ as before, but the $\mathrm{K}^{+}$signal at 39 amu is considerably more intense than the $\mathrm{NO}^{+}$, and $\mathrm{SO}_{2}{ }^{+}$peaks. There are also many features that can be atributed to alkali chlorides. The two peaks at 74 and 76 amu can be assigned to $\mathrm{KCl}^{+}$although the two peaks at 113 and 115 amu also have the characteristic intensity pattern for a species containing a single chlorine atom. These peaks are assigned to $\mathrm{K}_{2} \mathrm{Cl}^{+}$, a fragment ion of the $\mathrm{KCl}$ dimer. Sodium chloride is also released as indicated by the peaks at 58 and 60 amu corresponding to $\mathrm{NaCl}^{+}$. Although an abundance of alkali chlorides appear to be released, there does not appear to be any evidence of any other alkali containing species being released during the char combustion phase. As a result, the large $\mathrm{K}^{+}$and $\mathrm{Na}^{+}$signals are mostly due to fragmentation of the parent chloride species. Similar trends are also observed in the mass spectra associated with the char combustion phases of the other three herbaceous feedstocks. One curious feature is observed, however, in the char phase mass spectra of rice straw shown in Figure 17. Two unique peaks are evident at 97 and 99 amu and appear to have the characteristic intensity pattern of a species containing one chlorine atom. Given the high potassium and sodium content of this feedstock, these peaks are tentatively assigned to $\mathrm{KNaCl}^{+}$, a fragment of the mixed dimer of sodium and potassium chloride.

\section{The Effect of Temperature on Biomass Combustion}

The combustion behavior of planer shavings of lodgepole pine, eucalyptus, poplar, switchgrass and corn stover was investigated in a He/O $\mathrm{O}_{2}(20 \%)$ atmosphere at $1073 \mathrm{~K}$ to determine what effect temperature has on the release of alkali during biomass combustion. At the lower temperature, during the first phase of combustion, large amounts of organic hydrocarbons are released in addition to the $\mathrm{CO}_{2}, \mathrm{CO}, \mathrm{NO}$ and $\mathrm{SO}_{2}$ formed. This implies that volatiles combustion at the lower temperatures is not as complete as at higher temperatures. The ratio of alkali species to $\mathrm{HCl}$ and $\mathrm{SO}_{2}$ is still small during the combustion phase. As at the higher temperature, alkali is still primarily released during the char combustion phase. The char phase mass spectra for planer shavings, eucalyptus, poplar, switchgrass and corn stover are presented in Figures 20-24, respectively. Once again, the spectra have been normalized to the background ${ }^{34} \mathrm{O}_{2}^{+}$signal to preserve the semiquantitative nature of the relative intensities.

Several differences are observed between the lower temperature char phase mass spectra and the higher temperature data. Comparing the mass spectra presented in Figures 13 and 20 for the char combustion phase of planer shavings of lodgepole pine at $1373 \mathrm{~K}$ and $1073 \mathrm{~K}$, respectively, one 


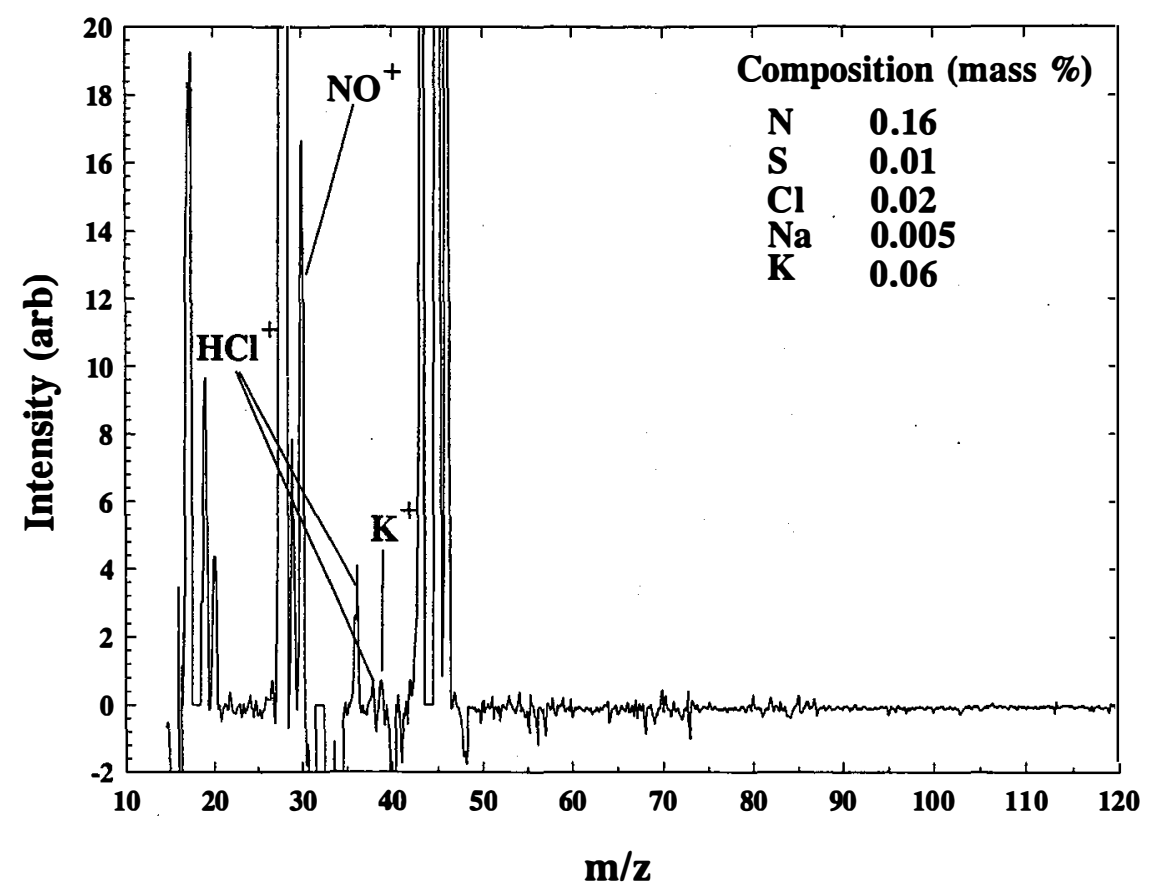

Figure 20. Mass spectrum (normalized to the background ${ }^{34} \mathrm{O}_{2}$ signal intensity) recorded during the char combustion phase of Planer Shavings of lodgepole pine batch combustion at $1073 \mathrm{~K}$ in a flowing $20 \% \mathrm{O}_{2}$ in helium atmosphere. The composition listed in the inset is from the ultimate analysis of the feedstock "as received."

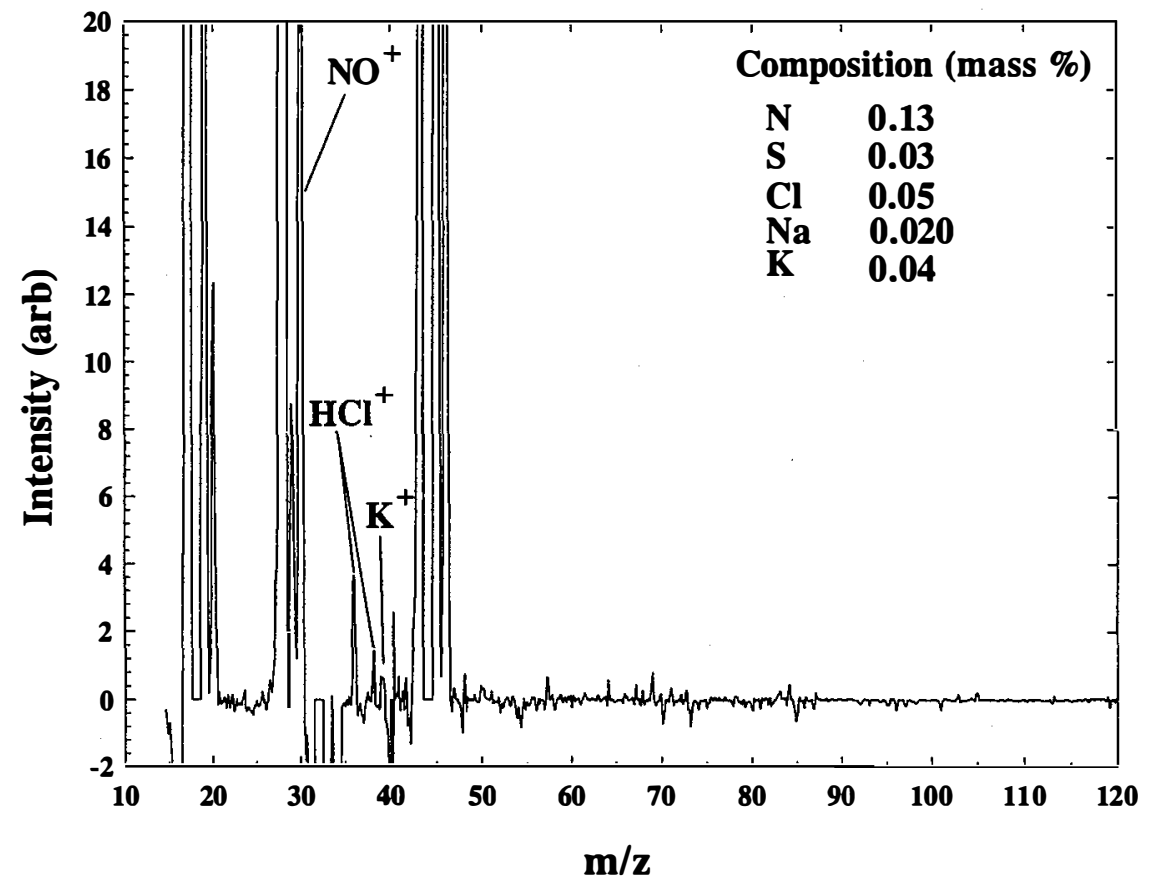

Figure 21. Mass spectrum (normalized to the background ${ }^{34} \mathrm{O}_{2}$ signal intensity) recorded during the char combustion phase of Eucalyptus batch combustion at $1073 \mathrm{~K}$ in a flowing $20 \%$ $\mathrm{O}_{2}$ in helium atmosphere. The composition listed in the inset is from the ultimate analysis of the feedstock "as received." 
TP-5597

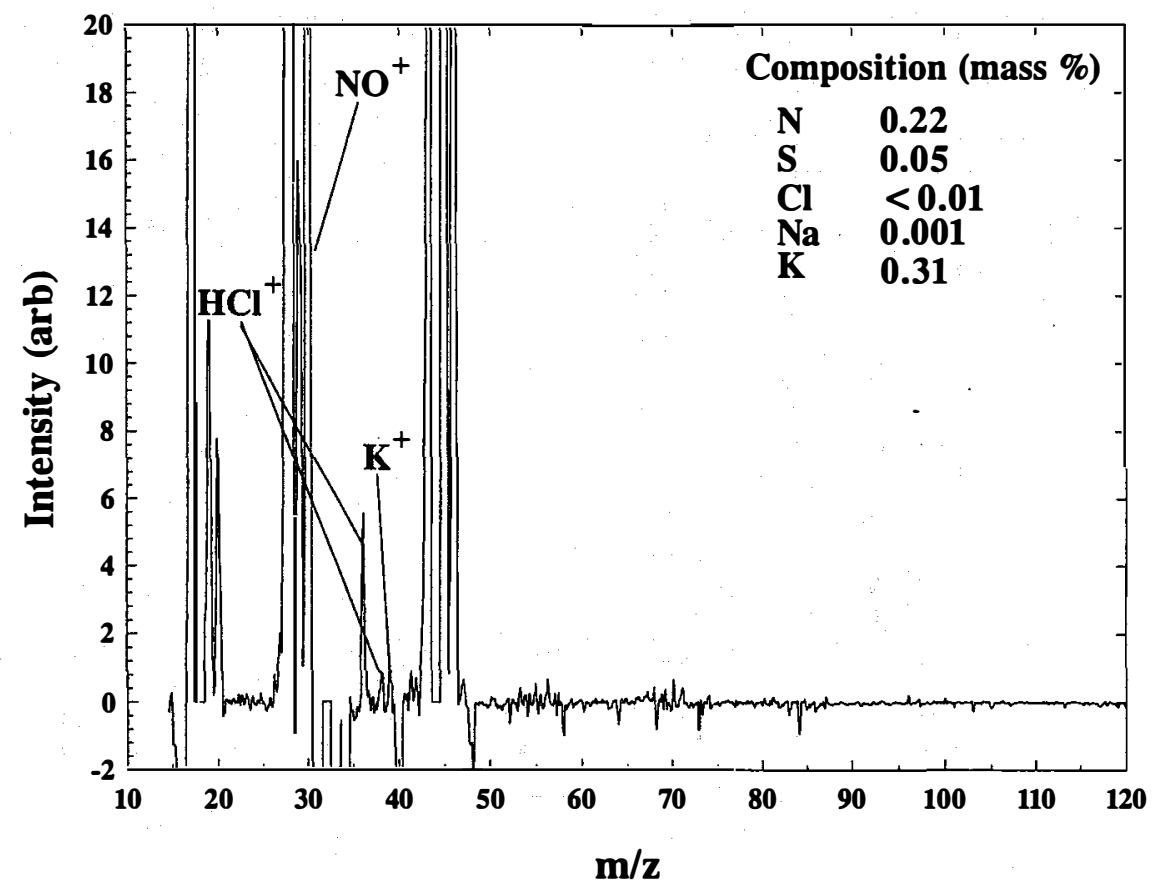

Figure 22. Mass spectrum (normalized to the background ${ }^{34} \mathrm{O}_{2}$ signal intensity) recorded during the char combustion phase of Poplar batch combustion at $1073 \mathrm{~K}$ in a flowing $20 \% \mathrm{O}_{2}$ in helium atmosphere. The composition listed in the inset is from the ultimate analysis of the feedstock "as received."

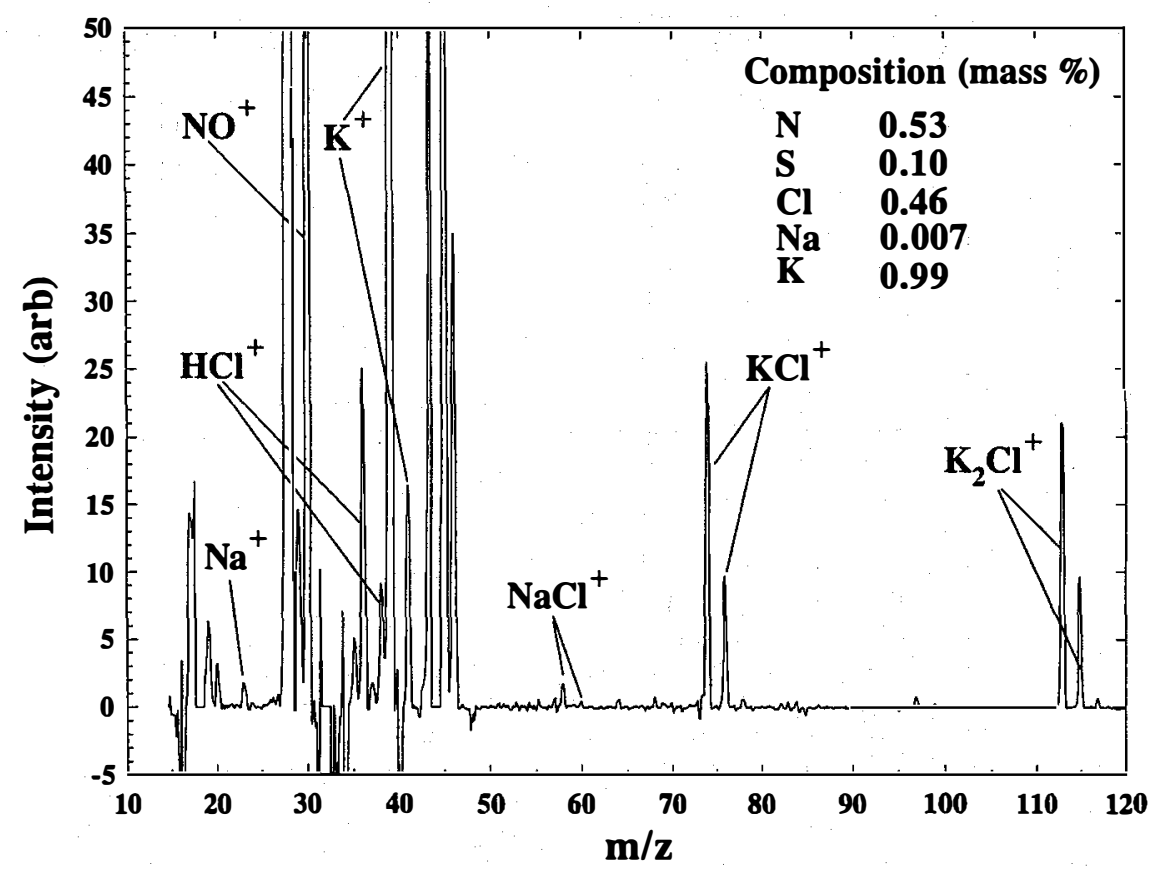

Figure 23. Mass spectrum (normalized to the background ${ }^{34} \mathrm{O}_{2}$ signal intensity) recorded during the char combustion phase of Swltchgrass batch combustion at $1073 \mathrm{~K}$ in a flowing $20 \%$ $\mathrm{O}_{2}$ in helium atmosphere. The composition listed in the inset is from the ultimate analysis of the feedstock "as received." 


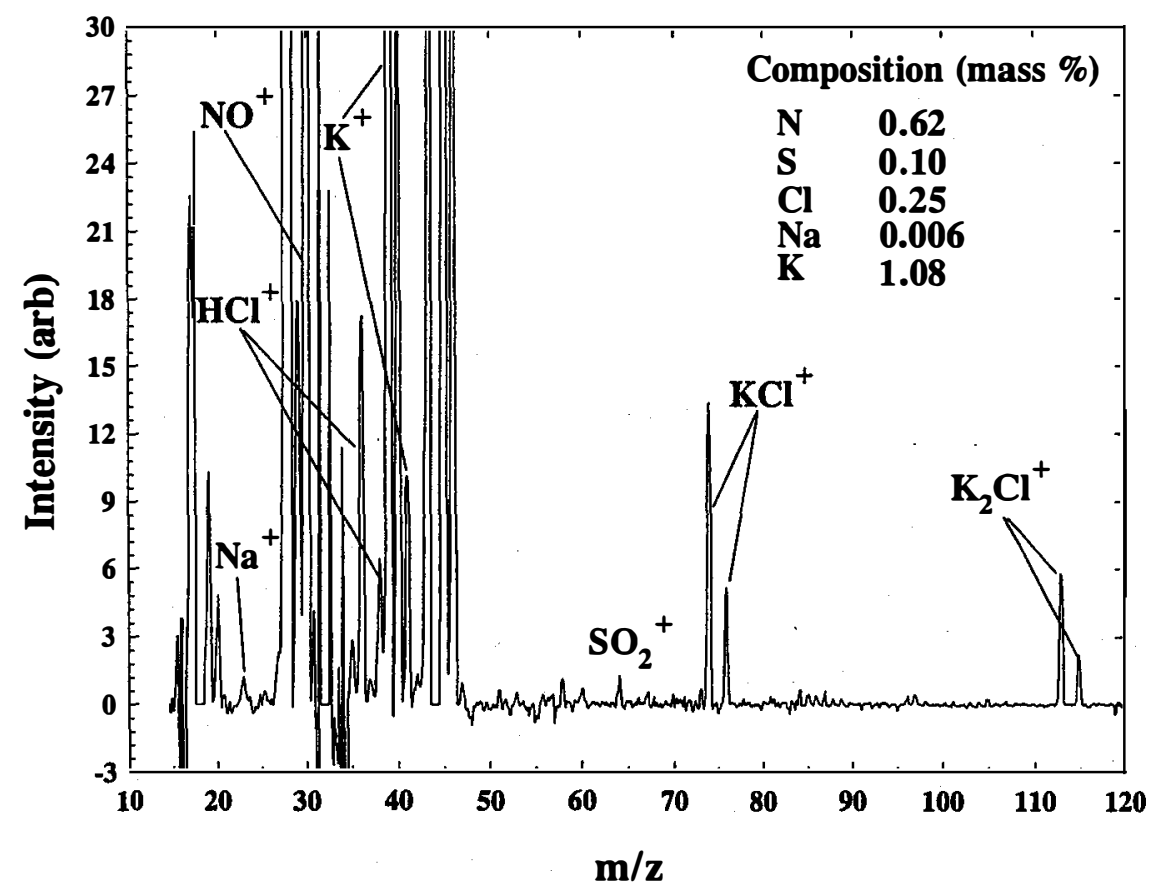

Figure 24. Mass spectrum (normalized to the background ${ }^{34} \mathrm{O}_{2}$ signal intensity) recorded during the char combustion phase of Corn Stover batch combustion at $1073 \mathrm{~K}$ in a flowing $20 \%$ $\mathrm{O}_{2}$ in helium atmosphere. The composition listed in the inset is from the ultimate analysis of the feedstock "as received."

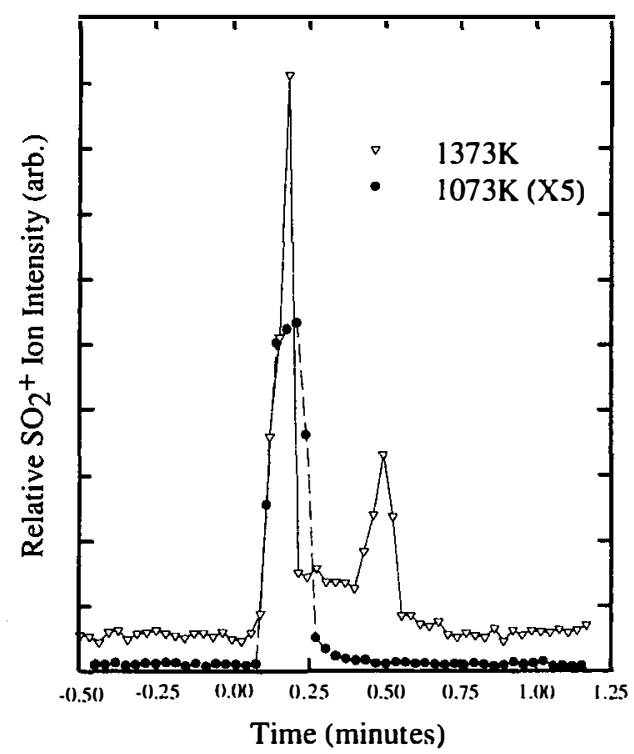

Figure 25. Time versus intensity profiles of the $\mathrm{SO}_{2+}$ ion $(\mathrm{m} / \mathrm{z}=64)$ recorded during switchgrass combustion in a flowing $20 \% \mathrm{O}_{2}$ in helium atmosphere at $1073 \mathrm{~K}$ (filled circles) and 1373K (open triangles). Time zero corresponds to when the sample was inserted into the hot part of the reactor. Relative heights of the profile reflect relative intensities. 
combustion phase. The switchgrass samples in each case were comparable indicating that this is in fact a temperature dependent phenomenon and not a function of sample size.

A more significant difference in regards to the present study is that less alkali is released at the lower combustion temperature. This is most dramatically observed in the mass spectra recorded during the char combustion phase of the woody biomass feedstocks. For example, in the char phase mass spectrum of planer shavings combusted at $1373 \mathrm{~K}$ shown in Figure 13 , the ratio of the $\mathrm{NO}^{+}$to $\mathrm{K}^{+}$ peaks is approximately one. At $1073 \mathrm{~K}$, the $\mathrm{NO}^{+}$signal intensity is approximately 16 times greater than the $\mathrm{K}^{+}$signal in Figure 20. At the higher temperature there is also evidence of $\mathrm{Na}^{+}$at 23 amu whereas at $1073 \mathrm{~K}$ this peak is not observed. Similar trends are also observed with eucalyptus and poplar. This argument assumes that NO production and the ionization cross sections of the species of interest are also not greatly affected by temperature.

For the herbaceous biomass feedstocks, switchgrass and corn stover, the amount of alkali released also appears to be less at lower combustion temperatures. Comparing the mass spectra recorded during the char combustion phase of switchgrass at 1373K (Figure 16) and 1073K (Figure 23), the relative intensity of the $\mathrm{KCl}^{+}$peaks (74 and $76 \mathrm{amu}$ ) and the $\mathrm{NO}^{+}$peak (30 amu) is close to unity at $1373 \mathrm{~K}$ and about one-half at $1073 \mathrm{~K}$. The difference in relative intensities of the $\mathrm{KCl}^{+}$and $\mathrm{K}_{2} \mathrm{Cl}^{+}$ peaks at the two temperatures may be an indication of different amounts of $\mathrm{KCl}$ being liberated, however, the difference can probably be accounted for by the change in the thermodynamic equilibrium between the $\mathrm{KCl}$ monomer and dimer as a function of temperature (Hastie, Zmbov, and Bonnell, 1984). Examining of the time traces for $\mathrm{K}^{+}$and $\mathrm{KCl}^{+}$in Figure 26a,b recorded during the

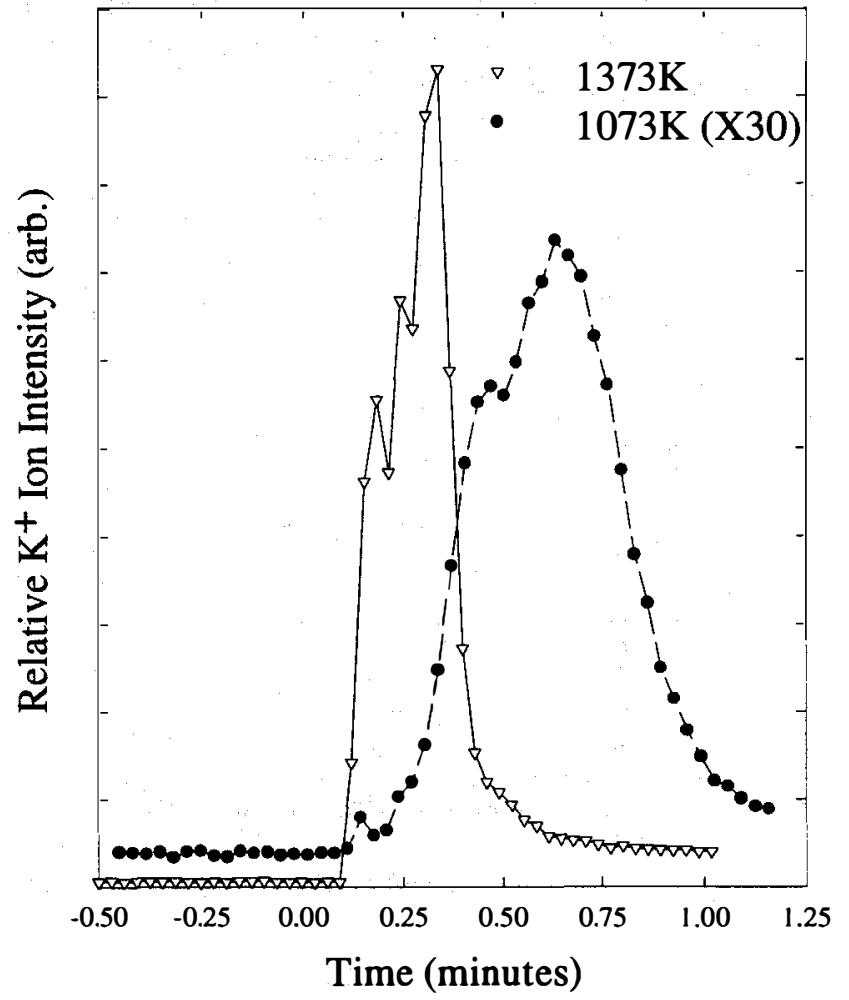

Figure 26a. Time versus intensity profiles of a) the $\mathrm{K}^{+}$ion $(\mathrm{m} / \mathrm{z}=39)$ and $\left.\mathrm{b}\right)$ the $\mathrm{KCl}^{+}$ion $(\mathrm{m} / \mathrm{z}=74)$ recorded during switchgrass combustion in a flowing $20 \% \mathrm{O}_{2}$ in helium atmosphere at 1073K (filled circles) and 1373K (open triangles). Time zero corresponds to when the sample was inserted into the hot region of the reactor. Relative heights of the profiles reflect actual intensities. 


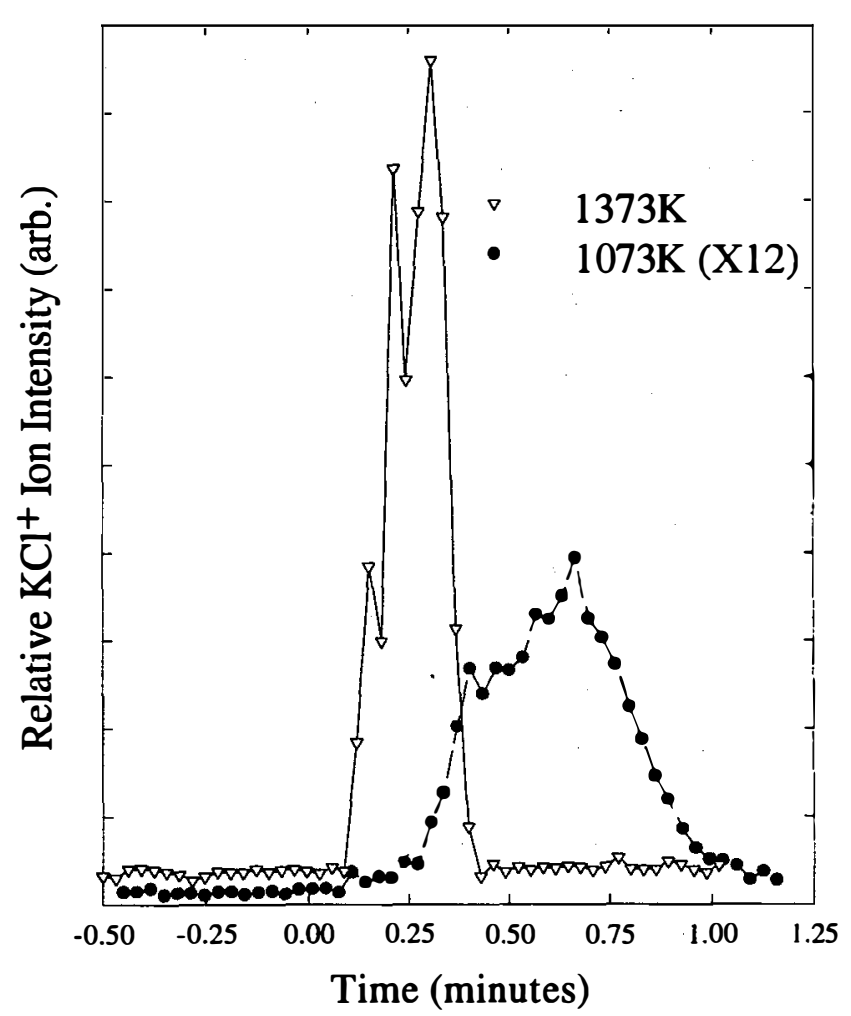

Figure 26b.

char combustion phase of switchgrass at the two different temperatures indicates that $\mathrm{K}^{+}$and $\mathrm{KCl}^{+}$ have similar intensity profiles in time at both combustion temperatures. At the higher temperature, however, the alkali release is more prompt while at the lower combustion temperature the alkali is released over a larger time period, suggesting inorganic evaporation.

\section{The Effect of Oxygen Concentration on Biomass Combustion}

The oxygen concentration in the reactor atmosphere was reduced to $5 \%$ in helium to observe any possible effects on the release of alkali during combustion of the seven biomass feedstocks being investigated in this study. The temperature in the reactor was maintained at $1373 \mathrm{~K}$ to compare with the results from the $20 \% \mathrm{O}_{2}$ screening experiments. The major effect that the reduced oxygen concentration has on biomass combustion occurs in the volatiles combustion phase. At the lower oxygen concentration, a significant amount of organic hydrocarbons are liberated. The characteristic mass peaks at $78 \mathrm{amu}\left(\mathrm{C}_{6} \mathrm{H}_{6}{ }^{+}\right)$and $92 \mathrm{amu}\left(\mathrm{C}_{7} \mathrm{H}_{8}{ }^{+}\right)$tend to dominate the spectrum in this phase of the combustion. The reduced oxygen concentration during the initial stage of combustion does not allow for complete conversion of hydrocarbons to $\mathrm{CO}_{2}$ and $\mathrm{H}_{2} \mathrm{O}$. In the char combustion phase, however, few differences are observed due to the lower oxygen concentration. Figures 27-33 display the char phase mass spectra recorded during the combustion of the seven biomass feedstocks of interest in the present study.

Two obvious differences in the mass spectra of the three woody feedstocks are the presence of peaks at $26 \mathrm{amu}$ and 82 and $81 \mathrm{amu}$. The peak at $26 \mathrm{amu}$ is tentatively assigned to the $\mathrm{C}_{2} \mathrm{H}_{2}{ }^{+}$ion. Apparently some hydrocarbons survive even during the char combustion phase. The peaks at 81 and $82 \mathrm{amu}$ differ by the loss of one hydrogen and are tentatively assigned to the $\mathrm{HSO}_{3}{ }^{+}$and $\mathrm{H}_{2} \mathrm{SO}_{3}{ }^{+}$ ions. This assignment has not been confirmed and is merely conjecture at this point. At the lower 
oxygen concentration, the $\mathrm{HCl}^{+}$peaks are much less intense than in the $20 \% \mathrm{O}_{2}$ data. The ratio of the $\mathrm{NO}^{+}$and $\mathrm{K}^{+}$peak intensities also changes dramatically at lower oxygen concentration. The $\mathrm{NO}^{+}$ peak is less than half as intense as the $\mathrm{K}^{+}$peak at $5 \%$ oxygen concentration (Figure 27) whereas at $20 \%$ oxygen concentration the ratio of the intensities of these two peaks is almost unity (Figure 13). At this time it is difficult to explain this difference in terms of more alkali being released or less NO being formed without actually quantifying the mass spectral data. At a reduced oxygen concentration it appears plausible to assume that less NO is being formed.

A reduced oxygen concentration does not appear to significantly affect the combustion properties of the four herbaceous biomass feedstocks. The tentatively assigned peaks at $26 \mathrm{amu}$ and 81 and 82 amu are observed in the char phase mass spectra of switchgrass, rice straw, wheat straw and corn stover (Figures 30-33). The relative intensity of the 26 amu peak is considerably larger in the switchgrass and corn stover spectra compared to the spectra associated with the straws. The relative intensity of the 81 and 82 amu peaks appears to be consistent in the char phase mass spectra of the four herbaceous feedstocks. The $\mathrm{HCl}^{+}$peaks at 36 and $38 \mathrm{amu}$ are observed in all four char phase spectra and the relative intensity of these peaks appears to be unaffected by the change in oxygen concentration. The relative intensity of the $\mathrm{NO}^{+}$and $\mathrm{K}^{+}$peaks also appears to be unaffected by the change in oxygen concentration during combustion of the herbaceous feedstocks. An apparent result of the lower oxygen concentration is an increased release of $\mathrm{NaCl}\left(\mathrm{Na}^{+}\right.$at 23 amu and $\mathrm{NaCl}^{+}$at 58 and $60 \mathrm{amu}$ ) during the char phase combustion. This is most obvious for corn stover (Figures 19 and 33). Overall, reducing the oxygen concentration appears to affect the combustion of the woody feedstocks more dramatically than the combustion of the herbaceous feedstocks.

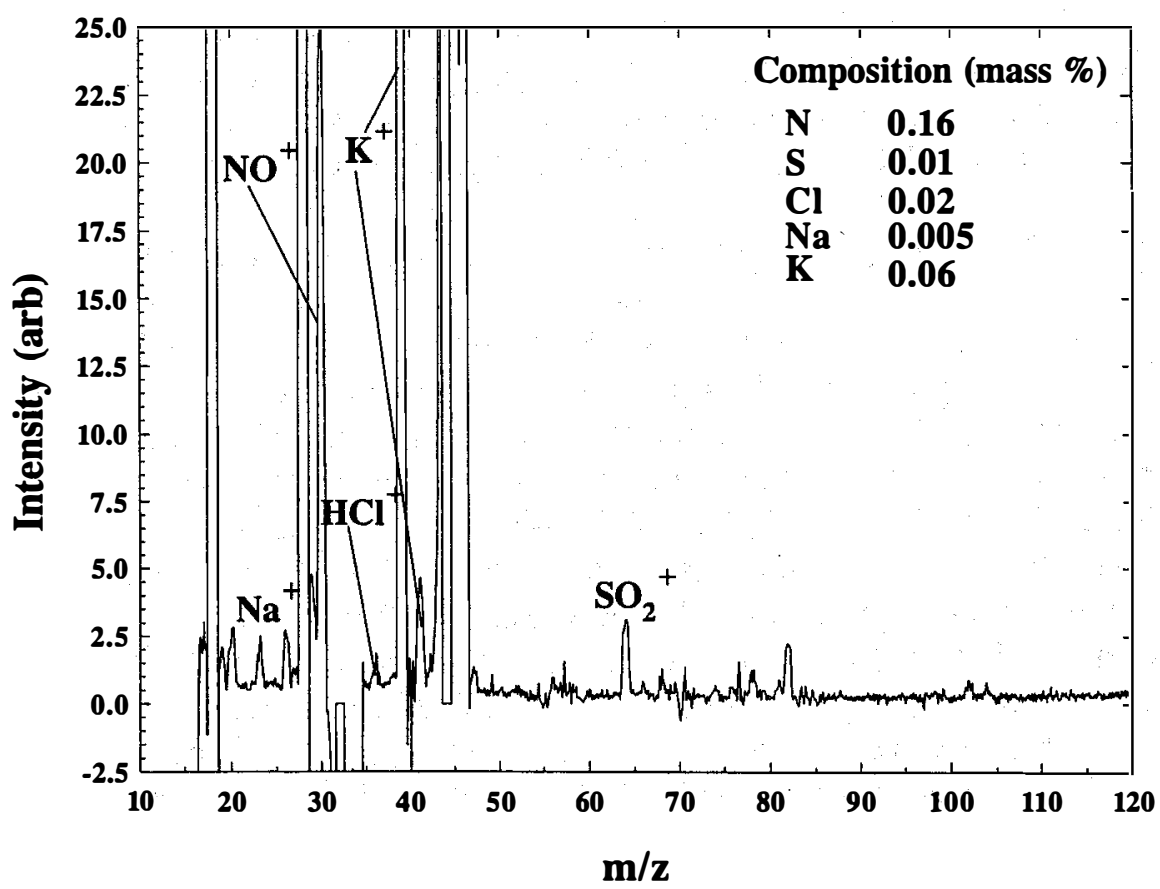

Figure 27. Mass spectrum (normalized to the background ${ }^{\mathrm{AH}} \mathrm{O}_{2}$ signal intensity) recorded during the char combustion phase of Planar Shavings of lodgepole pine batch combustion at $1373 \mathrm{~K}$ in a flowing $5 \% \mathrm{O}_{2}$ in helium atmosphere. The composition listed in the inset is from the ultimate analysis of the feedstock "as received." 


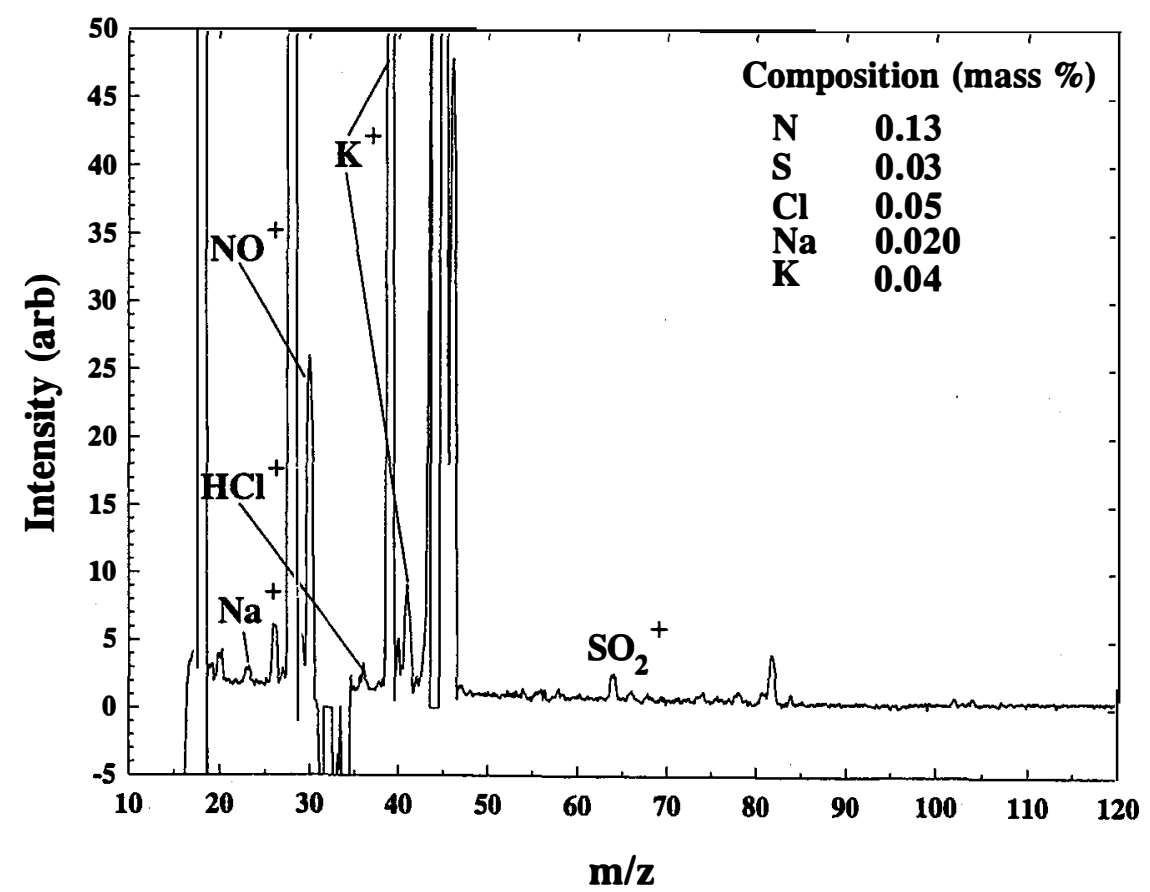

Figure 28. Mass spectrum (normalized to the background ${ }^{34} \mathrm{O}_{2}$ signal intensity) recorded during the char combustion phase of Eucalyptus batch combustion at $1373 \mathrm{~K}$ in a flowing $5 \%$ $\mathrm{O}_{2}$ in helium atmosphere. The composition listed in the inset is from the ultimate analysis of the feedstock "as received."

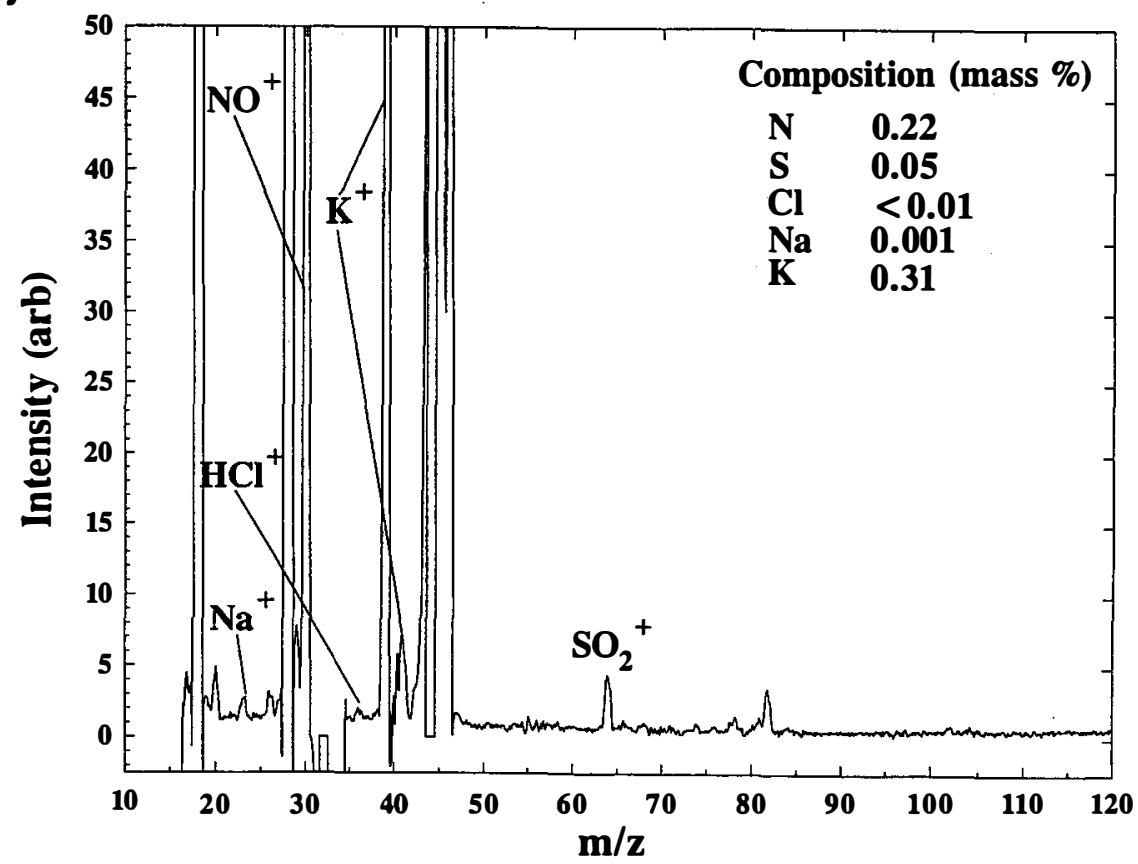

Figure 29. Mass spectrum (normalized to the background ${ }^{34} \mathrm{O}_{2}$ signal intensity) recorded during the char combustion phase of Poplar batch combustion at $1373 \mathrm{~K}$ in a flowing $5 \% \mathrm{O}_{2}$ in helium atmosphere. The composition listed in the inset is from the ultimate analysis of the feedstock "as received." 


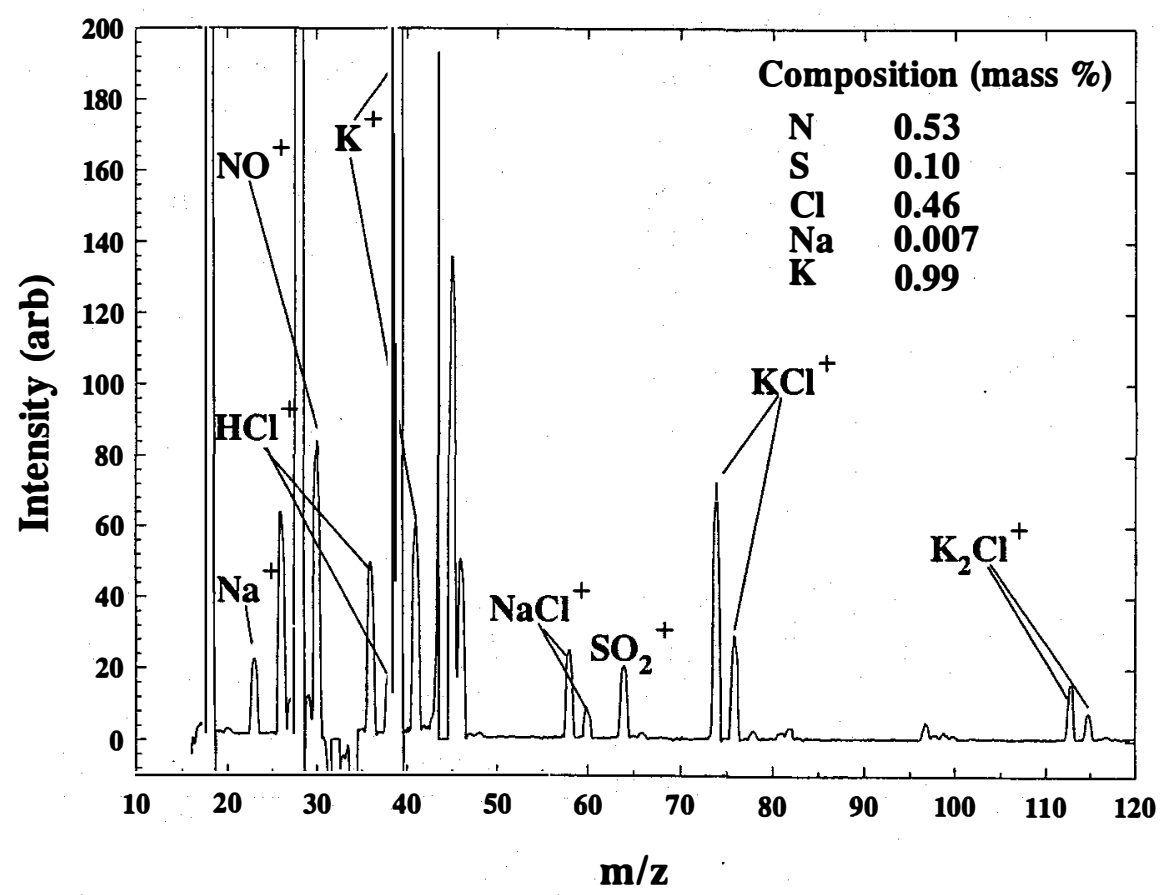

Figure 30. Mass spectrum (normalized to the background ${ }^{34} \mathrm{O}_{2}$ signal intensity) recorded during the char combustion phase of Switchgrass batch combustion at $1373 \mathrm{~K}$ in a flowing $5 \%$ $\mathrm{O}_{2}$ in helium atmosphere. The composition listed in the inset is from the ultimate analysis of the feedstock "as received."

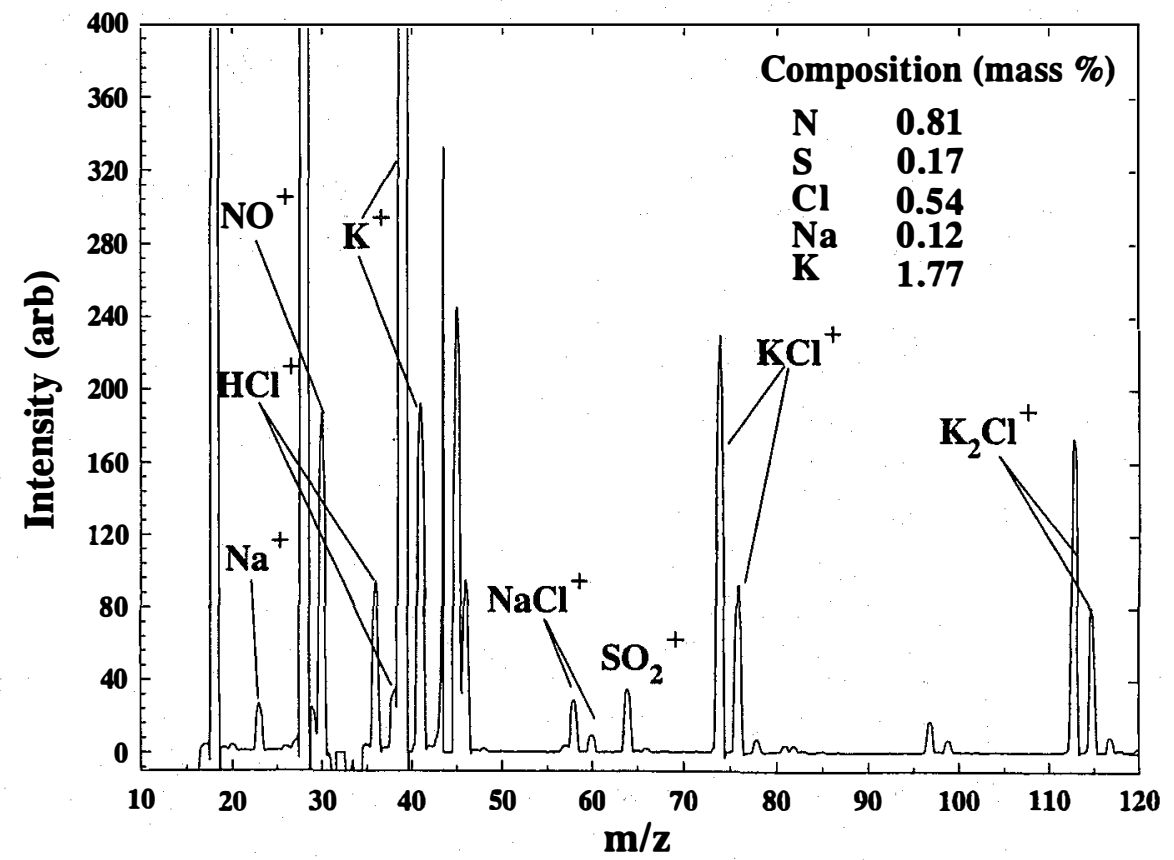

Figure 31. Mass spectrum (normalized to the background ${ }^{34} \mathrm{O}_{2}$ signal intensity) recorded during the char combustion phase of Rice Straw batch combustion at $1373 \mathrm{~K}$ in a flowing $5 \%$ $\mathrm{O}_{2}$ in helium atmosphere. The composition listed in the inset is from the ultimate analysis of the feedstock "as received." 


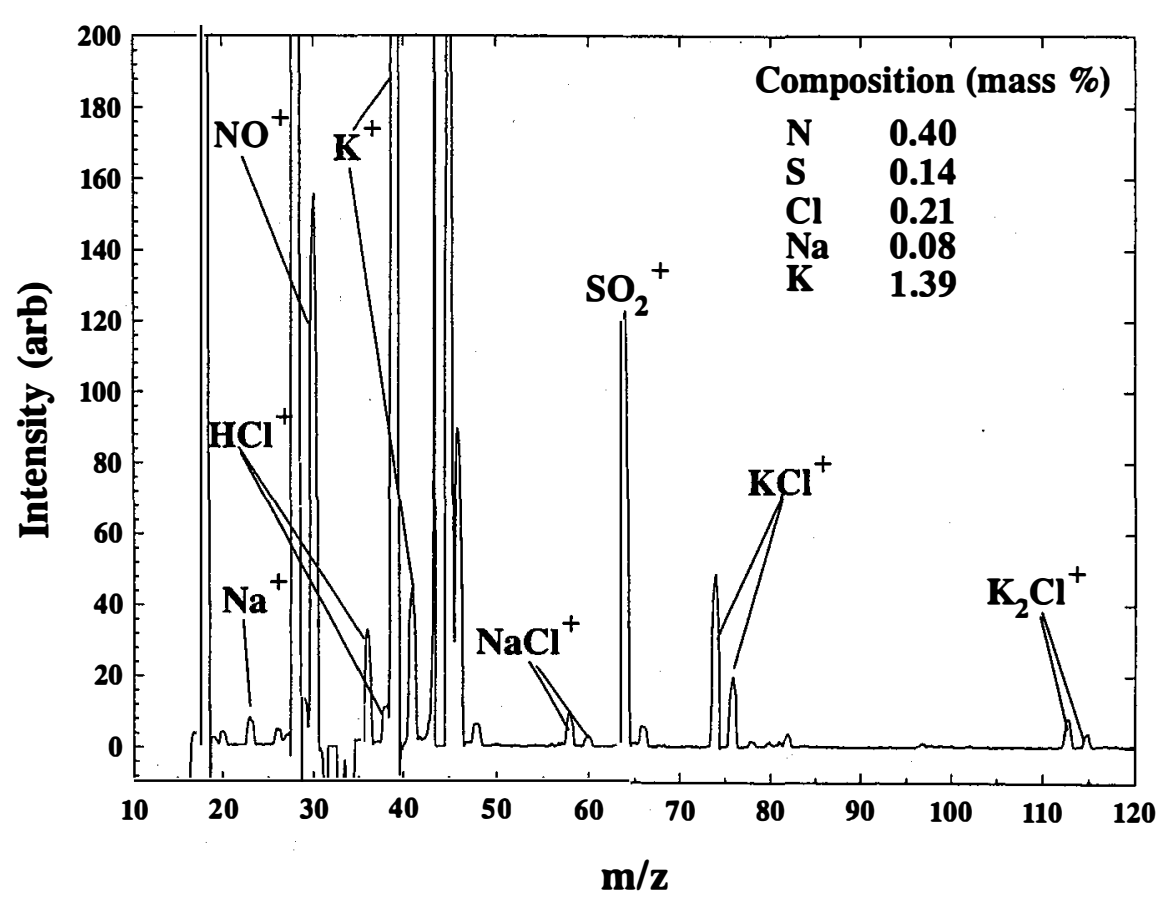

Figure 32. Mass spectrum (normalized to the background ${ }^{34} \mathrm{O}_{2}$ signal intensity) recorded during the char combustion phase of Wheat Straw batch combustion at $1373 \mathrm{~K}$ in a flowing $5 \%$ $\mathrm{O}_{2}$ in helium atmosphere. The composition listed in the inset is from the ultimate analysis of the feedstock "as received."

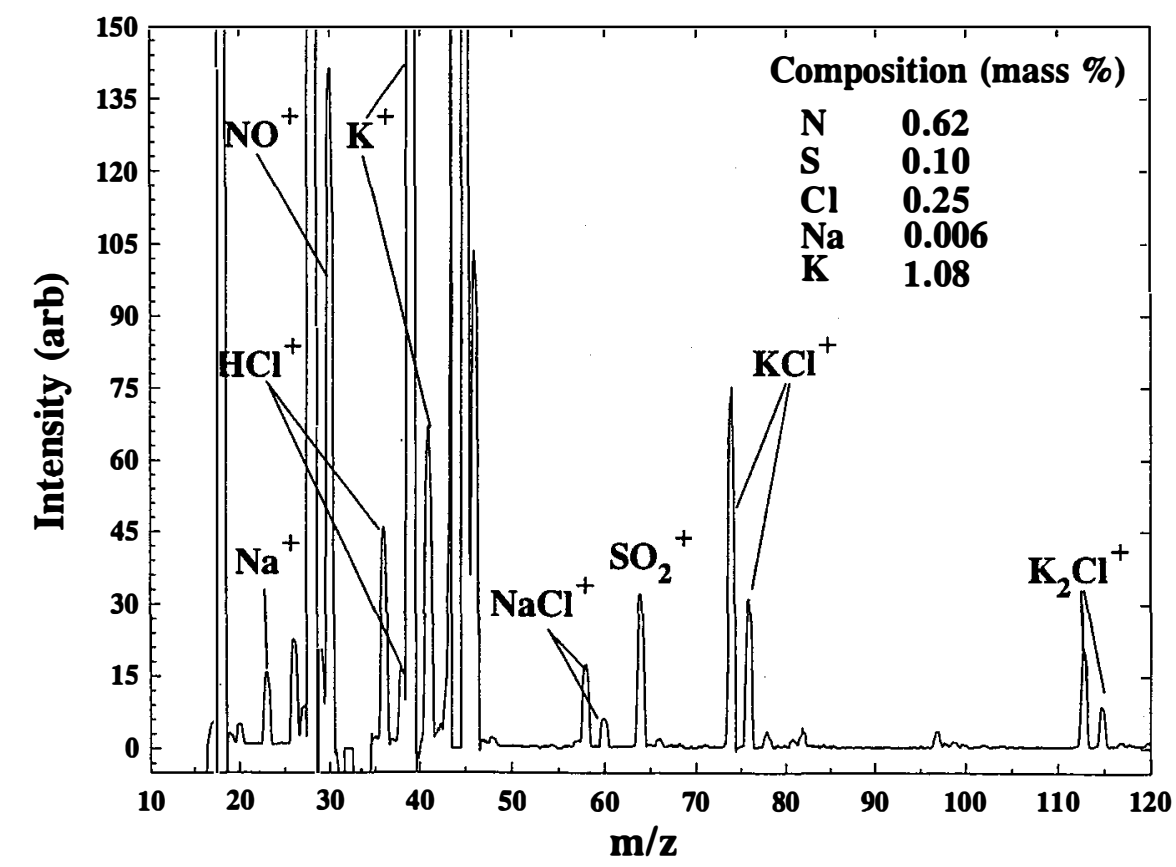

Figure 33. Mass spectrum (normalized to the background ${ }^{34} \mathrm{O}_{2}$ signal intensity) recorded during the char combustion phase of Corn Stover batch combustion at $1373 \mathrm{~K}$ in a flowing $5 \%$ $\mathrm{O}_{2}$ in helium atmosphere. The composition listed in the inset is from the ultimate analysis of the feedstock "as received." 


\section{The Effect of Added Steam on Biomass Combustion}

The combustion of eucalyptus, poplar, switchgrass and corn stover was investigated with $8 \%$ steam added to the $\mathrm{He} / \mathrm{O}_{2}$ environment. The purpose of these experiments was to better simulate the conditions in the continuous combustion environment that occurs in a typical boiler or turbine combustor. In these industrial environments, a fairly constant level of steam would be produced by the combustion process in a continuously fed system as opposed to a dry char combustion phase which results from the batch sample combustion in the current laboratory reactor. Therefore, the effects of added steam were investigated by comparing the results to the previous screening results. The mass spectra recorded during the char combustion phase of eucalyptus, poplar, switchgrass and corn stover in $18 \% \mathrm{O}_{2}$ and $8 \%$ steam in helium at $1373 \mathrm{~K}$ are presented in Figures 34-37, respectively.

Adding steam to the reactor atmosphere has little affect on the major features of the char phase mass spectra, with the exception of new features appearing at 56 and 57 amu in several of the char phase mass spectra. Subtle differences in the char phase mass spectra of eucalyptus with and without steam (Figures 14 and 34) are noticed. For instance, the $\mathrm{K}^{+}$to $\mathrm{NO}^{+}$ratio and the $\mathrm{K}^{+}$to $\mathrm{HCl}^{+}$is larger in the absence of steam. This implies a decrease in alkali release, however, this would require quantification of the alkali signals in the two spectra to confirm this claim. A new feature at $56 \mathrm{amu}$ is observed in the mass spectrum recorded during the char combustion phase of poplar in steam. This peak is assigned to $\mathrm{KOH}^{+}$, indicating that some fraction of the alkali released is in the form of the hydroxide. Switchgrass combustion in a steam atmosphere also indicates the evidence of potassium hydroxide release (Figure 36). There is a small peak at $56 \mathrm{amu}$, however, a more dominant peak at 57 amu is present. This feature is tentatively assigned to $\mathrm{KH}_{2} \mathrm{O}^{+}$, however, the mechanism of forming this ion is not well understood. Confirming this assignment will require further study. Comparing the char phase mass spectra of switchgrass with and without steam (Figures 16 and 36) reveals that the $\mathrm{K}^{+}$to $\mathrm{HCl}^{+}$and the $\mathrm{KCl}^{+}$to $\mathrm{SO}_{2}^{+}$ratios are both smaller with steam added to the combustion atmosphere. This is an indication that alkali release is being shifted from potassium chloride to potassium hydroxide. Further indication of this can be seen in Figure 38a,b which displays the ion intensity versus time profiles for $\mathrm{K}^{+}, \mathrm{KCl}^{+}$, and $\mathrm{KH}_{2} \mathrm{O}^{+}$recorded during the combustion of switchgrass with and without steam. In the absence of steam, the $\mathrm{K}^{+}$and $\mathrm{KCl}^{+}$ions have identical behavior in time. When steam is added, however, the $\mathrm{K}^{+}$signal has a different time profile than $\mathrm{KCl}^{+}$. This could indicate a shift in alkali release to other species in the presence of steam. Similar trends are also observed in the char phase mass spectrum of corn stover combustion in steam (Figure 37). In this case, however, the $\mathrm{KCl}^{+}$to $\mathrm{SO}_{2}{ }^{+}$ratio is constant with and without steam and the features at $56\left(\mathrm{KOH}^{+}\right)$and $57\left(\mathrm{KH}_{2} \mathrm{O}^{+}\right)$amu are of comparable intensity.

\section{Comparisons With Equilibrium Calculations}

An equilibrium analysis of biomass combustion was undertaken to further investigate the details of alkali speciation under various conditions. The calculations were performed using a modified version of STANJAN (Reynolds, 1986), a thermodynamic equilibrium computer code which minimizes the Gibbs free energy of the system by the method of element potentials with atom population constraints. The theory relates the mole fraction of each species to element potentials for which there is one for each independent atom in the system. This method is particularly suited to large systems because the element potentials and the total number of moles in each phase are the only variables as opposed to using individual reactions and rates for species formation. For more information on the mechanics and mathematics of the program, the reader is referred to the literature (Reynolds 1986; Van Zeggemon and Storey 1970). The main program has been modified to accept up to 600 species and 50 phases (Hildenbrand and Lau 1993). A comprehensive database of species and related thermodynamic data is used to predict the equilibrium gas and condensed phase compositions given 


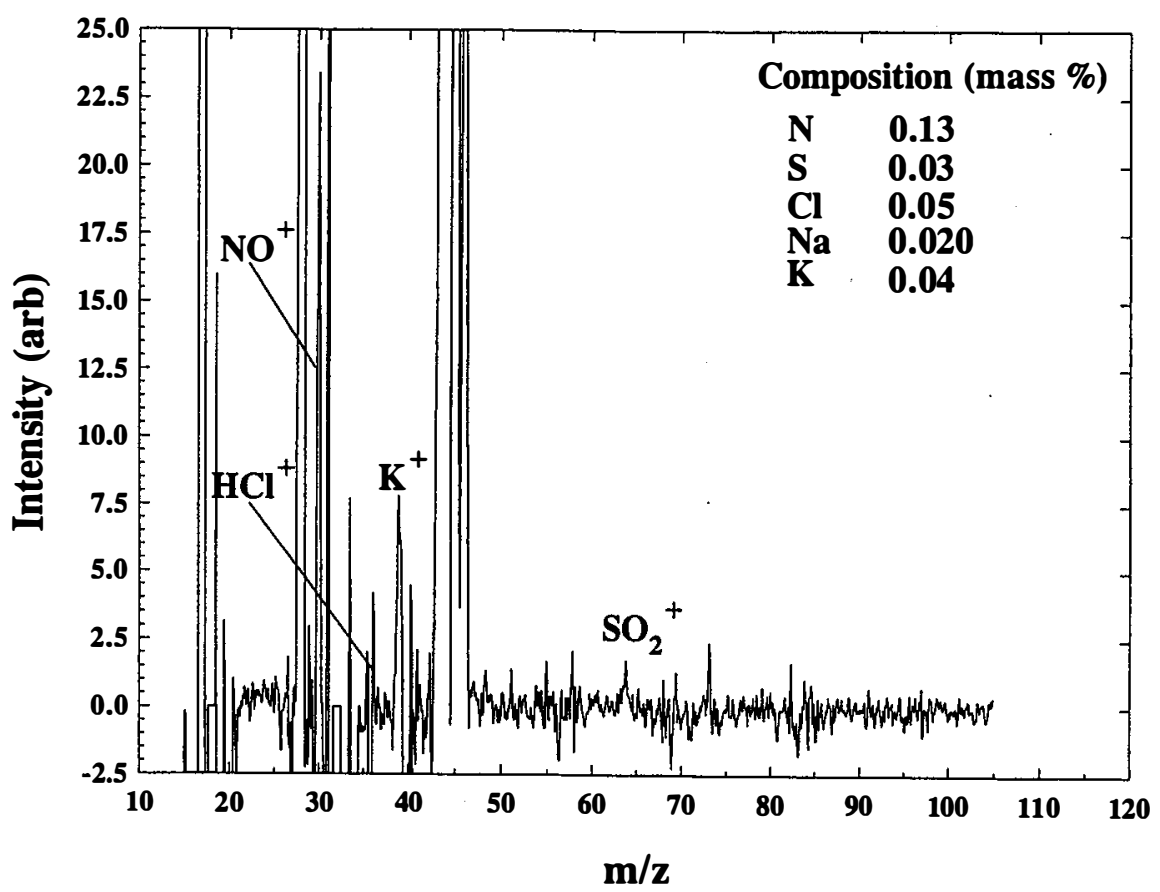

Figure 34. Mass spectrum (normalized to the background ${ }^{34} \mathrm{O}_{2}$ signal intensity) recorded during the char combustion phase of Eucalyptus batch combustion at $1373 \mathrm{~K}$ in a flowing $10 \%$ $\mathrm{O}_{2}$ and $8 \%$ steam in helium atmosphere. The composition listed in the inset is from the ultimate analysis of the feedstock "as received."

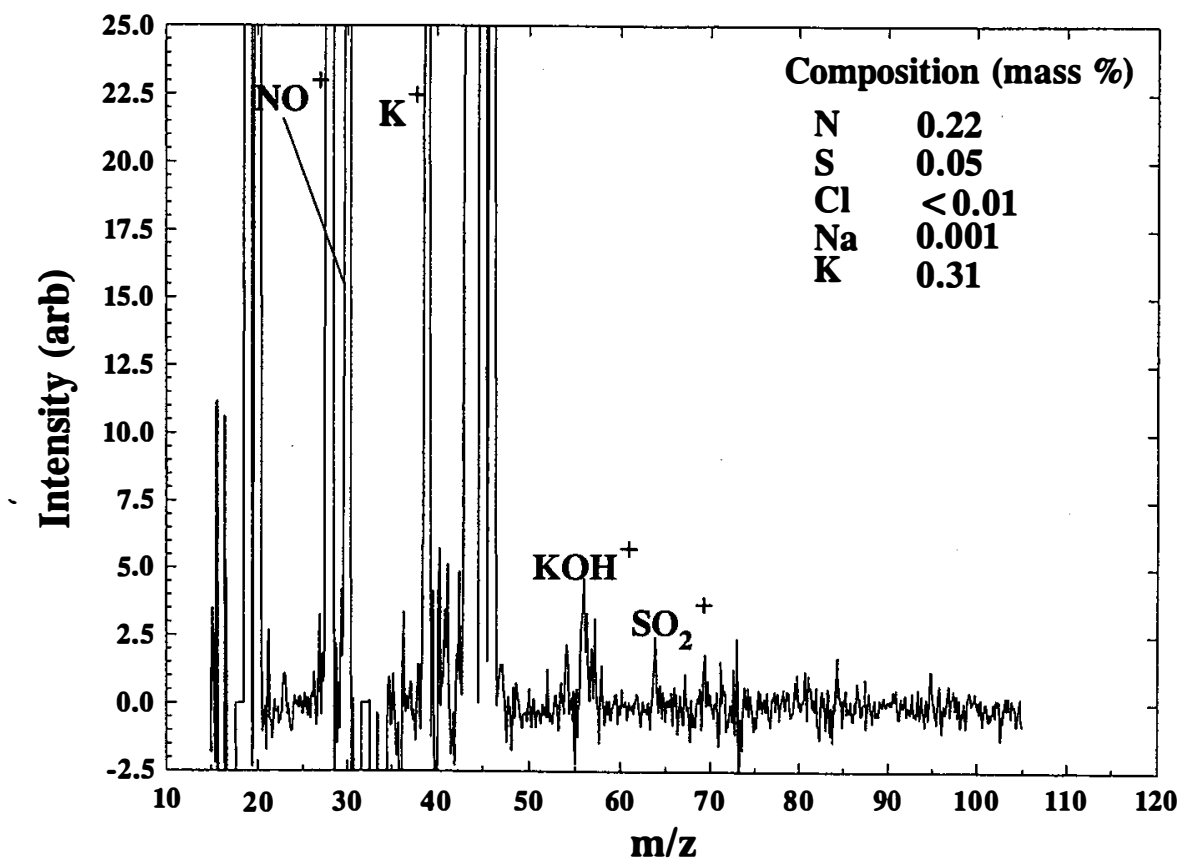

Figure 35. Mass spectrum (normalized to the background ${ }^{34} \mathrm{O}_{2}$ signal intensity) recorded during the char combustion phase of Poplar batch combustion at $1373 \mathrm{~K}$ in a flowing $10 \% \mathrm{O}_{2}$ and $8 \%$ steam in helium atmosphere. The composition listed in the inset is from the ultimate analysis of the feedstock "as received." 


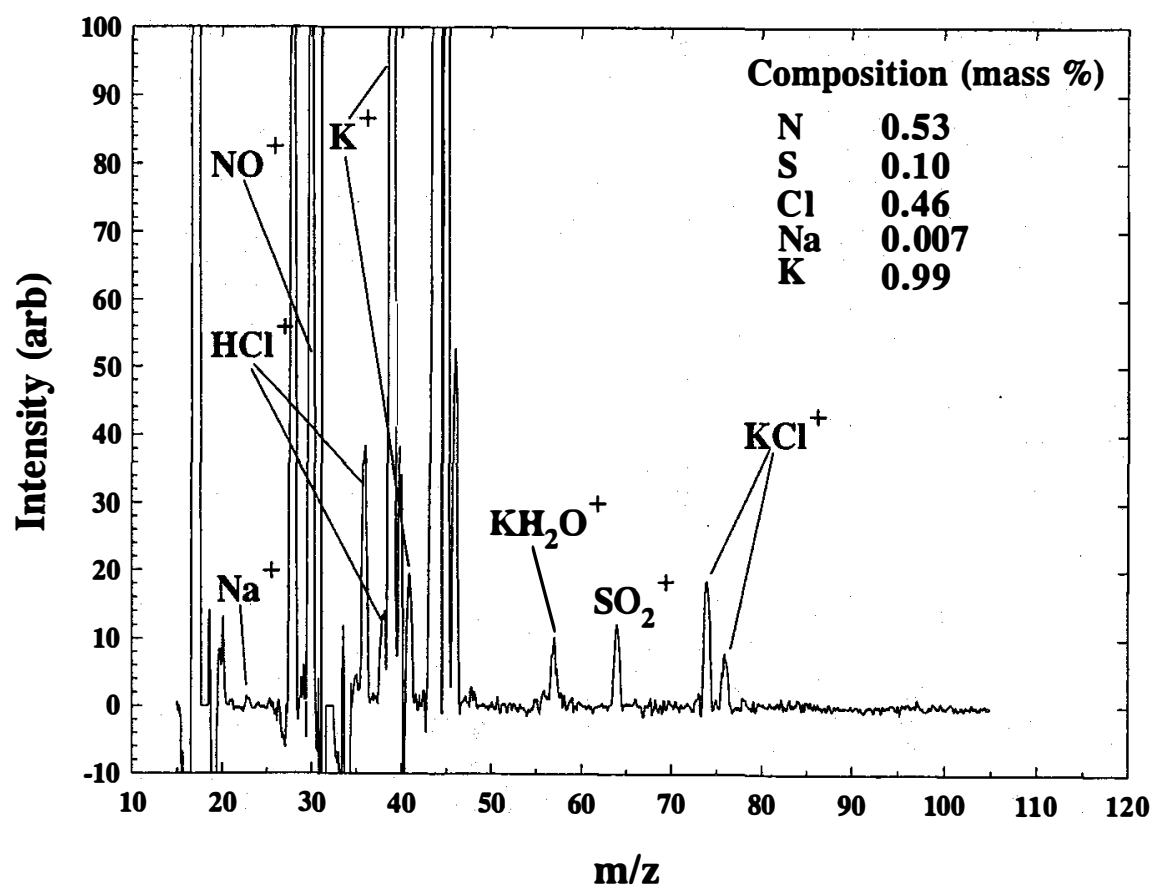

Figure 36. Mass spectrum (normalized to the background ${ }^{34} \mathrm{O}_{2}$ signal intensity) recorded during the char combustion phase of Switchgrass batch combustion at $1373 \mathrm{~K}$ in a flowing $18 \%$ $\mathrm{O}_{2}$ and $8 \%$ steam in helium atmosphere. The composition listed in the inset is from the ultimate analysis of the feedstock "as received."

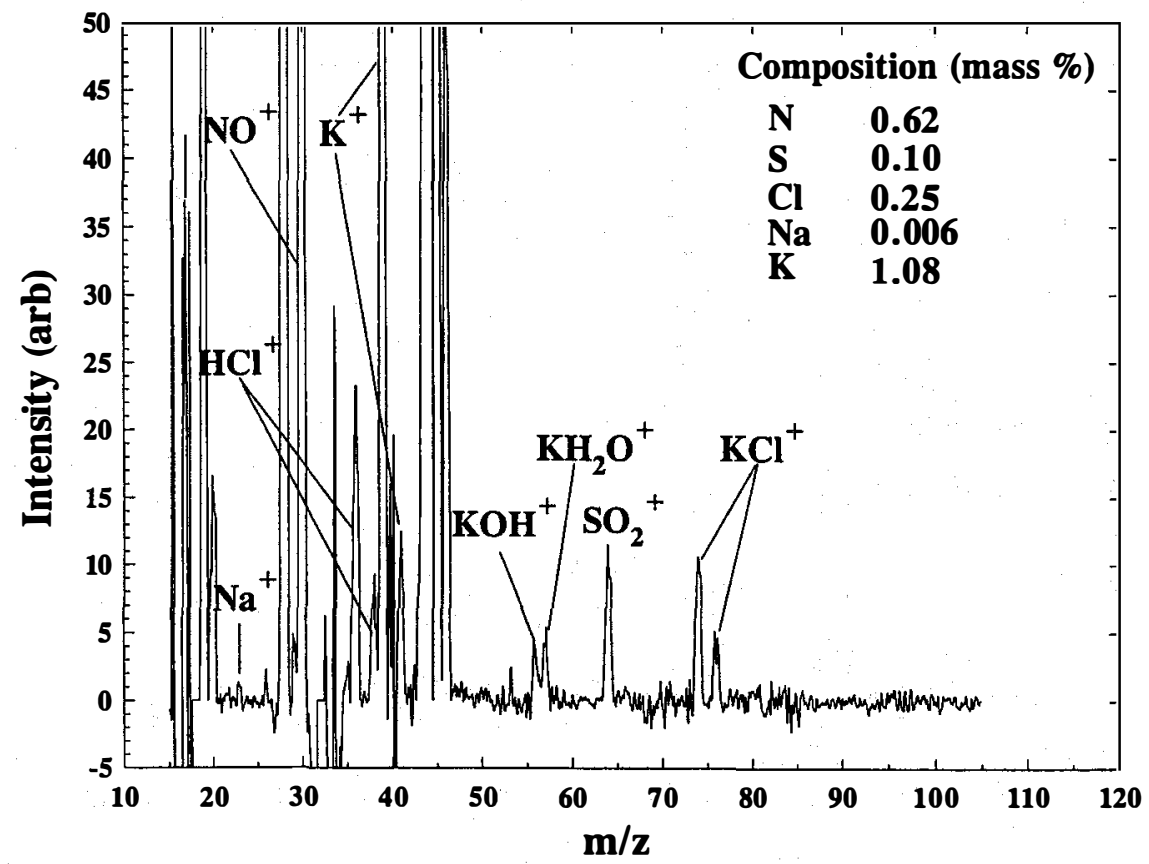

Figure 37. Mass spectrum (normalized to the background ${ }^{34} \mathrm{O}_{2}$ signal intensity) recorded during the char combustion phase of Corn Stover batch combustion at $1373 \mathrm{~K}$ in a flowing $18 \%$ $\mathrm{O}_{2}$ and $8 \%$ steam in helium atmosphere. The composition listed in the inset is from the ultimate analysis of the feedstock "as received." 
TP-5597

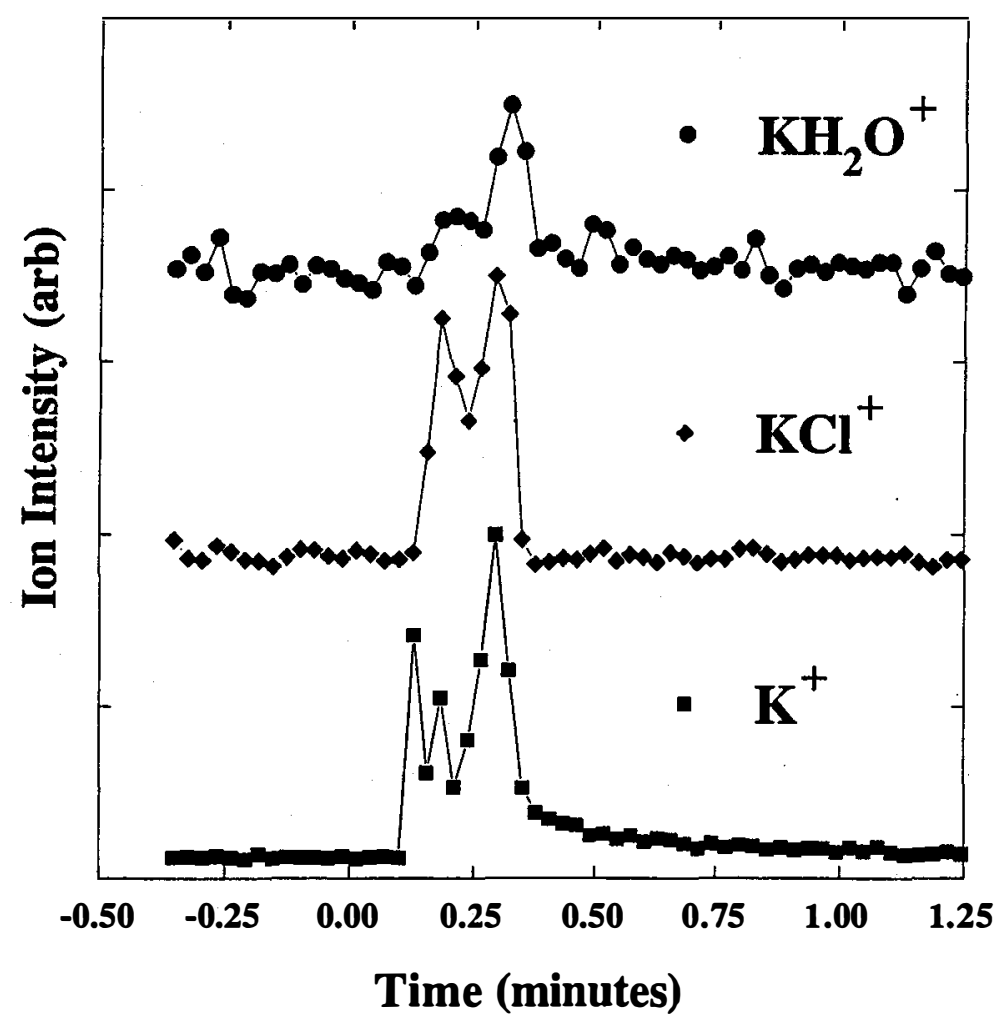

Figure 38a. Time versus intensity profiles of various species recorded during the combustion of switchgrass at $1373 \mathrm{~K}$ in a flowing $\mathrm{O}_{2}$ in helium atmosphere a) with added steam.

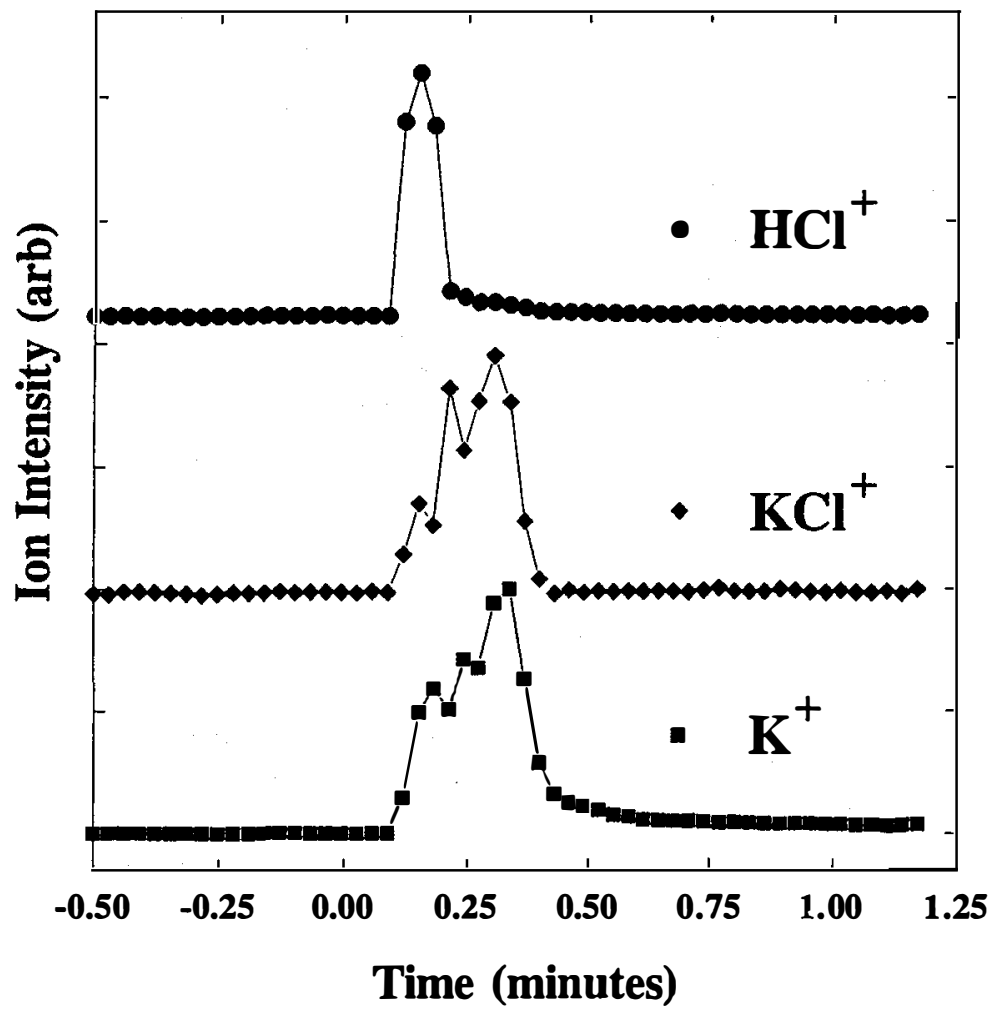

Figure 38b. Without added steam. Time zero corresponds to when the samples were inserted into the hot region of the furnace. 
an initial temperature and pressure as well as the populations of the following atoms: $\mathrm{Al}, \mathrm{Ba}, \mathrm{C}, \mathrm{Ca}$, $\mathrm{Cl}, \mathrm{Fe}, \mathrm{H}, \mathrm{K}, \mathrm{Mg}, \mathrm{Mn}, \mathrm{N}, \mathrm{Na}, \mathrm{O}, \mathrm{P}, \mathrm{S}$, and $\mathrm{Si}$. The purpose of the equilibrium calculations at this point in the study is not to quantitatively model given combustion experiments, but to qualitatively investigate changes in equilibrium product formation during different combustion conditions. Initial atom populations were based on the ultimate analysis of switchgrass in different combustion environments. Results are presented for calculations of switchgrass combustion in an atmosphere with an air-to-fuel ratio of 7.1 (20\% excess air) at $1373 \mathrm{~K}$ and $1073 \mathrm{~K}$. Switchgrass combustion in an atmosphere with a steam-to-fuel ratio of 1.5 (10\% excess steam) and an $\mathrm{O}_{2}$ (from air for stoichiometric combustion) to fuel ratio of 1.19 (air-to-fuel $=5.65$ ) at $1373 \mathrm{~K}$ was also investigated. The results of these calculations yielded extensive lists of products at the three conditions studied. Mass fractions of some of the more abundant and important gas and condensed phase species are tabulated in Table 15.

Several general trends in the calculations for switchgrass in air at $1373 \mathrm{~K}$ can be seen by comparing the results in Table 15 to the char phase mass spectrum in Figure 16. The calculations predict that $\mathrm{CO}_{2}$ is the main combustion product as expected, however, the calculated $\mathrm{CO}$ concentration in the gas phase is six orders of magnitude lower. The magnitude of the $\mathrm{CO}^{+}$signal in the char phase spectrum suggests that there is much more $\mathrm{CO}$ than the calculations predict. Clearly, converting $\mathrm{CO}$ to $\mathrm{CO}_{2}$ is kinetically limited. The calculations predict that the major alkali species formed are $\mathrm{KCl}$ and $\mathrm{NaCl}$ and that the $\mathrm{KCl}$ dimer is thermodynamically stable at this temperature. This is consistent with the char phase mass spectrum of switchgrass (Figure 16) at $1373 \mathrm{~K}$ in $\mathrm{He} / \mathrm{O}_{2}(20 \%)$. In fact, many of the species that have a relatively high calculated mass fraction can be identified in the char phase mass spectrum. The major condensed phase species are $\mathrm{SiO}_{2}$ and $\mathrm{K}_{3} \mathrm{PO}_{4}$.

Instead of comparing the calculations to the experimental results directly, it is more beneficial to compare the calculated results for different combustion conditions. For instance, by changing the combustion temperature, the relative fractions of the major combustion products $\mathrm{CO}_{2}, \mathrm{H}_{2} \mathrm{O}, \mathrm{N}_{2}$, and $\mathrm{O}_{2}$ do not change. There is less $\mathrm{KCl}$ in the gas phase at lower temperatures, however, the relative amount (compared to the monomer) of the $\mathrm{KCl}$ dimer increases at lower temperatures. This is not surprising because the $\mathrm{KCl}$ dimer is more thermodynamically stable at lower temperatures (Hastie, Zmbov, and Bonnell 1984). The decrease in $\mathrm{KCl}$ in the gas phase at lower temperatures correlates with an increase in $\mathrm{KCl}$ in the condensed phase. The most obvious difference between the two calculations is that the $\mathrm{SO}_{2}$ mass fraction is three orders of magnitude smaller at 1073K compared to $1373 \mathrm{~K}$. Qualitatively, this is observed in the mass spectral data for switchgrass char combustion. The spectrum recorded at $1373 \mathrm{~K}$ (Figure 16) displays a prominent $\mathrm{SO}_{2}{ }^{+}$peak at $64 \mathrm{amu}$ which is not observed in the spectrum recorded at 1073K (Figure 23). There appears to be a correlation between the amount of $\mathrm{SO}_{2}$ in the gas phase and the amount of $\mathrm{K}_{2} \mathrm{SO}_{4}$ in the condensed phase. For instance, at $1073 \mathrm{~K}$ there is 10 times more condensed phase $\mathrm{K}_{2} \mathrm{SO}_{4}$ and 1000 times less $\mathrm{K}_{2} \mathrm{SO}_{4}$ in the gas phase compared to the $1373 \mathrm{~K}$ results.

The calculations for switchgrass combustion in a steam atmosphere show a dramatic increase in the amount of $\mathrm{H}_{2} \mathrm{O}$ and $\mathrm{H}_{2}$, as expected, and $\mathrm{CO}$ as well. The amount of $\mathrm{O}_{2}$ in the product distribution is also considerably decreased when steam is added to the atmosphere. The available fuel-nitrogen is more completely converted to $\mathrm{N}_{2}$ in the steam atmosphere as indicated by the lower NO mass fraction. Alkali release is still predominantly in the form of $\mathrm{KCl}$, however, the mass fraction of $\mathrm{KOH}$ increases when steam is added to the combustion atmosphere. This is also observed experimentally. 
Table 15. Results of Equilibrium Calculations for Switchgrass Combustion at Different Conditions

\begin{tabular}{|c|c|c|c|}
\hline Gas Phase Species & $\begin{array}{c}\text { Air/Fuel = } 7.1 \\
T=1373 K \\
\text { (20\% Excess Air) } \\
\text { Mass Fraction }\end{array}$ & $\begin{array}{c}\text { Air/Fuel = } 7.1 \\
T=1073 \mathrm{~K} \\
\text { (20\% Excess Air) } \\
\text { Mass Fraction }\end{array}$ & $\begin{array}{c}\text { Steam/Fuel = } 1.5 \\
\text { Air/Fuel = 5.65 } \\
T=1373 \mathrm{~K} \\
\text { (Stoichiometric + } \\
10 \% \text { Excess Steam) } \\
\text { Mass Fraction }\end{array}$ \\
\hline $\mathrm{CO}_{2}$ & $4.52 \times 10^{-1}$ & $4.52 \times 10^{-1}$ & $2.06 \times 10^{-1}$ \\
\hline co & $5.01 \times 10^{-7}$ & $5.04 \times 10^{-10}$ & $2.66 \times 10^{-3}$ \\
\hline $\mathrm{N}_{2}$ & $2.50 \times 10^{-1}$ & $2.50 \times 10^{-1}$ & $5.16 \times 10^{-1}$ \\
\hline $\mathrm{H}_{2} \mathrm{O}$ & $1.61 \times 10^{-1}$ & $1.61 \times 10^{-1}$ & $2.69 \times 10^{-1}$ \\
\hline $\mathrm{O}_{2}$ & $1.23 \times 10^{-1}$ & $1.23 \times 10^{-1}$ & $1.08 \times 10^{-9}$ \\
\hline $\mathrm{H}_{2}$ & $1.53 \times 10^{-8}$ & $3.43 \times 10^{-11}$ & $2.99 \times 10^{-4}$ \\
\hline $\mathrm{KCl}$ & $1.33 \times 10^{-3}$ & $1.43 \times 10^{-4}$ & $6.08 \times 10^{-4}$ \\
\hline $\mathrm{HCl}$ & $6.27 \times 10^{-4}$ & $8.18 \times 10^{-4}$ & $3.12 \times 10^{-4}$ \\
\hline $\mathrm{SO}_{2}$ & $4.80 \times 10^{-4}$ & $2.37 \times 10^{-7}$ & $2.64 \times 10^{-4}$ \\
\hline NO & $2.68 \times 10^{-4}$ & $2.86 \times 10^{-5}$ & $3.61 \times 10^{-8}$ \\
\hline $\mathrm{NaCl}$ & $3.68 \times 10^{-5}$ & $3.10 \times 10^{-6}$ & $1.78 \times 10^{-5}$ \\
\hline $\mathrm{OH}$ & $1.82 \times 10^{-5}$ & $3.37 \times 10^{-7}$ & $2.39 \times 10^{-7}$ \\
\hline $\mathrm{SO}_{3}$ & $1.59 \times 10^{-5}$ & $8.41 \times 10^{-8}$ & $7.49 \times 10^{-10}$ \\
\hline $\mathrm{K}_{2} \mathrm{Cl}_{2}$ & $8.59 \times 10^{-6}$ & $7.90 \times 10^{-6}$ & $1.51 \times 10^{-6}$ \\
\hline $\mathrm{KOH}$ & $6.55 \times 10^{-6}$ & $1.79 \times 10^{-8}$ & $1.01 \times 10^{-5}$ \\
\hline $\mathrm{Cl}$ & $3.51 \times 10^{-6}$ & $4.49 \times 10^{-7}$ & $1.36 \times 10^{-8}$ \\
\hline $\mathrm{NO}_{2}$ & $2.58 \times 10^{-6}$ & $1.14 \times 10^{-6}$ & $2.97 \times 10^{-13}$ \\
\hline $\mathrm{K}_{2} \mathrm{SO}_{4}$ & $6.83 \times 10^{-7}$ & $1.82 \times 10^{-9}$ & $3.84 \times 10^{-11}$ \\
\hline $\mathrm{NaOH}$ & $1.68 \times 10^{-7}$ & $3.43 \times 10^{-10}$ & $2.37 \times 10^{-7}$ \\
\hline $\mathrm{Na}_{2} \mathrm{SO}_{4}$ & $3.42 \times 10^{-9}$ & $2.56 \times 10^{-11}$ & $2.13 \times 10^{-13}$ \\
\hline \multicolumn{4}{|l|}{$\begin{array}{c}\text { Condensed Phase } \\
\text { Species }\end{array}$} \\
\hline $\mathrm{SiO}_{2}$ & $3.85 \times 10^{-3}$ & $4.65 \times 10^{-3}$ & $1.72 \times 10^{-3}$ \\
\hline $\mathrm{K}_{3} \mathrm{PO}_{4}$ & $2.64 \times 10^{-3}$ & $2.53 \times 10^{-3}$ & $1.29 \times 10^{-3}$ \\
\hline $\mathrm{KCl}$ & $9.40 \times 10^{-5}$ & $8.96 \times 10^{-4}$ & $1.63 \times 10^{-5}$ \\
\hline $\mathrm{K}_{2} \mathrm{SO}_{4}$ & $2.11 \times 10^{-4}$ & $1.54 \times 10^{-3}$ & $1.50 \times 10^{-7}$ \\
\hline
\end{tabular}




\section{Quantification of Alkali Released During Biomass Combustion}

The char phase mass spectra of the woody feedstocks recorded under various conditions are consistent with the compositional analyses that indicate that very little alkali is present in these feedstocks. The herbaceous feedstocks, on the other hand, have high alkali contents that are reflected in the char phase mass spectra. For these feedstocks, the major alkali species released under the various conditions studied is potassium chloride $(\mathrm{KCl})$. Depending on the feedstock, sodium chloride is also liberated in detectable quantities. Therefore, having identified the major alkali species released during biomass combustion, attempts were made to quantify the amount of $\mathrm{KCl}$ and $\mathrm{NaCl}$ released into the gas phase. This exercise is demonstrated for switchgrass combustion at $1373 \mathrm{~K}$ in $\mathrm{He} / \mathrm{O}_{2}(20 \%)$.

Quantification of alkali was accomplished by using $\mathrm{KCl}$ and $\mathrm{NaCl}$ calibration standards. The intensity and fragmentation patterns were compared between the mass spectra of the standards and biomass samples measured under identical mass spectrometer settings and furnace conditions. The calibration standards were aqueous solutions of $\mathrm{KCl}\left(4.87 \times 10^{-3} \mathrm{M}\right)$ and $\mathrm{NaCl}\left(2.81 \times 10^{-3} \mathrm{M}\right) .100 \mu \mathrm{l}$ samples were pipetted into quare boats and allowed to dry in room air. This procedure yielded microgram quantities of the alkali halide of interest that produced substantial ion intensities in the mass spectra without overloading the detector.

When the standards were inserted into the furnace it is assumed that all of the material is vaporized. In addition, any condensation of alkali onto the walls of the furnace is assumed to be the same for the standards and the biomass samples. The mass spectra of $\mathrm{KCl}$ and $\mathrm{NaCl}$ vapor displayed the characteristic ions for each species (Hastie, Zmbov, and Bonnell 1984, Bonnell and Hastie 1979, and Milne and Klein, 1960). The $\mathrm{NaCl}$ standard mass spectrum exhibited peaks at $23 \mathrm{amu}\left(\mathrm{Na}^{+}\right)$ and 58 and $60 \mathrm{amu}\left(\mathrm{NaCl}^{+}\right)$. The relative intensity of the 58 and $60 \mathrm{amu}$ peaks is three to one, characteristic of the natural isotopic abundance of ${ }^{35} \mathrm{Cl}$ and ${ }^{37} \mathrm{Cl}$. The relative intensity of the parent ion (58 amu) and the fragment ion (23 amu) is approximately 0.8 and is consistent with studies reported in the literature (Bonnell and Hastie, 1979; Hastie, Plante and Bonnell 1982). The KCl standard mass spectrum has peaks at $39 \mathrm{amu}\left(\mathrm{K}^{+}\right)$and 74 and $76 \mathrm{amu}\left(\mathrm{KCl}^{+}\right)$. The relative intensity of the 74 and 76 amu peaks is again characteristic of the chlorine isotopes. Potassium chloride, however, fragments more than $\mathrm{NaCl}$. The relative intensity of the parent (74 amu) peak and the fragment ion (39 amu) is approximately 0.05 as reported in the literature (Hastie, Zmbov, and Bonnell 1984).

Two methods were used to quantify the amount of $\mathrm{KCl}$ and $\mathrm{NaCl}$ released into the gas phase during switchgrass combustion and differed only in the way the data were processed. In the first method, absolute calibration was achieved by comparing the areas under the mass spectral peaks observed, multiplied by the time over which the spectrum was averaged. In the second method, absolute calibration was achieved by comparing the areas under the profiles of ion intensity versus time. In this way, all of the alkali was accounted for. The two methods gave comparable results so only method two will be discussed below.

Data from five switchgrass samples and four each of the $\mathrm{KCl}$ and $\mathrm{NaCl}$ standards were used to obtain a statistical average. For calibration purposes, the $74 \mathrm{amu}$ signal was used as a measure of $\mathrm{KCl}$ released and the 58 amu peak was used as a measure of $\mathrm{NaCl}$ released. The average area under the $74 \mathrm{amu}$ ion profiles in the $\mathrm{KCl}$ standards was $1518 \pm 433$ counts/min and the average area under the $58 \mathrm{amu}$ ion profile in the $\mathrm{NaCl}$ standards was $1708 \pm 626$ counts/min. The errors reported are one standard deviation. Because the amount of alkali released depends on the size of the switchgrass sample, it is more appropriate to report $\% \mathrm{~K}$ and $\% \mathrm{Na}$ released from the biomass samples. The average $\% \mathrm{~K}$ released from the switchgrass is $22.4 \pm 6.3$ and the average $\% \mathrm{Na}$ released is $269 \pm 100$. 
Clearly, the $\mathrm{NaCl}$ calibration and \% Na released are in error. This is most likely due to the fact that the signal-to-noise at 58 amu was poor because there are two orders of magnitude less sodium than potassium in switchgrass (according to the ultimate analysis).

A more useful way of presenting the amount of alkali released is in parts per million by volume inside a typical combustor. To calculate this quantity, the conditions in a typical boiler or industrial combustor must be assumed, combustion in $20 \%$ excess air. Assuming that each switchgrass sample undergoes combustion under these conditions, the average amount of potassium in the gas phase would be $275 \pm 77$ ppmv. A comparable calculation was attempted for switchgrass pyrolysis oil combustion. Preliminary results indicate that the potassium released into the gas phase was considerably less than in the solid, on the order of tens of ppmv.

Quantification has only been successfully done for potassium from $\mathrm{KCl}$. Clearly, to fully quantify the alkali released during biomass combustion it is necessary account for all of the different alkali species released. This requires calibration of a number of standards along with a library of mass spectra detailing fragmentation patterns of alkali species to deconvolute out the contributions of various species at similar mass peaks.

\section{Combustion of Switchgrass Pyrolysis Oil}

Another potential application of biomass is to pyrolize a given feedstock to produce an oil that could be used as an additive to or a substitute for petroleum fuels. Pyrolysis oils generally have quite different characteristics than the parent feedstock and little is known about the form of alkali in biomass pyrolysis oils. Having demonstrated the ability to monitor forms and amounts of alkali released during biomass combustion, experiments were conducted to investigate the alkali release during pyrolysis oil combustion. For these preliminary results, a switchgrass derived pyrolysis oil was combusted in the same manner as the biomass samples discussed above. The pyrolysis oil was produced in the NREL vortex fast pyrolysis reactor (run \#146-A) with a switchgrass feed rate of 12 $\mathrm{kg} / \mathrm{hr}$. The vortex reactor wall temperature was maintained at $625^{\circ} \mathrm{C}$ and the exit gas/vapor temperature was $525{ }^{\circ} \mathrm{C}$. A total liquid yield (organics plus water) of $45 \%$ was realized. Table 16 contains the proximate, ultimate and ash analysis for the switchgrass pyrolysis oil and the parent switchgrass feedstock (Czernik 1992). It is apparent that much of the alkali is lost during the pyrolysis, presumably to the char. However, it is not known what oil components; water, organics, or suspended chars, contain the greater portion of alkali.

Although the characteristics of the oil are quite different from the parent feedstock, the combustion behavior of the two samples are similar. The oil burning experiments, however, gave considerably noisier data compared to the solid feedstocks due to a rather unsteady burning of the oil, which gave random bursts of noise in the mass spectrometer (Wornat, 1993, observes microexplosions in single oil drop combustion, which may correlate with our observation). Such noise spikes have been associated with fine particulates in the sampled gas in prior MBMS sampling of "dirty" systems. Nevertheless, there still appears to be three distinct phases of combustion as in the biomass feedstock experiments. This can be observed in the time evolution of various species when $30 \mathrm{mg}$ of switchgrass oil is combusted in $20 \% \mathrm{O}_{2}$ in helium at 1373K (Figure 39). The dashed lines in the figure represent times at which the noise spikes resulting from the particulates occurred. In the case of the pyrolysis oil, as with the solid, most species except $\mathrm{NO}, \mathrm{CO}$ and alkali are released during the early, volatiles combustion phase. Potassium has an apparently later stage of release, though these preliminary results should not be overinterpretted.

Figure 40 shows mass spectra averaged over the char burning phase during the combustion of solid switchgrass and a $30 \mathrm{mg}$ sample of switchgrass oil, respectively in $20 \% \mathrm{O}_{2}$ in helium at $1373 \mathrm{~K}$. As 
Table 16. Composition of Switchgrass Pyrolysis Oil and the Parent Switchgrass Feedstock

\begin{tabular}{lcc}
\hline & $\begin{array}{c}\text { Switchgrass Oil } \\
\text { (wt \%) }\end{array}$ & $\begin{array}{c}\text { Solid Switchgrass } \\
\text { (wt \%) }\end{array}$ \\
\hline Moisture, as received & 24.4 & 2.2 \\
Ash, as received & 0.79 & 6.4 \\
Volatiles, as received & 65.5 & 75.0 \\
Fixed Carbon, as received & 9.3 & 18.6 \\
& & \\
$\mathrm{C}$, dry basis & 42.5 & 43.2 \\
$\mathrm{H}$, dry basis & 6.3 & 5.4 \\
$\mathrm{O}$, dry basis & 50.9 & 38.1 \\
& $(\mathrm{ppm}$ wt) & $(\mathrm{ppm}$ wt) \\
$\mathrm{N}$ & 2800 & 5000 \\
$\mathrm{~S}$ & 300 & 400 \\
$\mathrm{Cl}$ & -100 & -100 \\
$\mathrm{~K}$ & 740 & 5600 \\
$\mathrm{Ca}$ & 490 & 2800 \\
$\mathrm{Na}$ & 20 & 100 \\
$\mathrm{Si}$ & -- & 15800 \\
\hline
\end{tabular}

indicated by the sample analyses, the switchgrass solid has a higher level of alkali than the oil. This is obvious in the char phase mass spectra of the solid because the relative $\mathrm{K}^{+}$signal is much larger and the $\mathrm{KCl}^{+}$peaks are easily discernable. Very little alkali can be identified in the char phase spectrum of the oil.

\section{Discussion}

Molecular beam sampling/mass spectrometry has proven invaluable in studying biomass combustion. This is reflected in the results from the screening studies presented above that provide important insights into alkali speciation and release during biomass combustion. Combustion in a 20\% oxygen in helium atmosphere at $1373 \mathrm{~K}$ served as reference conditions for the present study. Several observations can be made concerning the reliability and usefulness of experiments conducted under ideal laboratory furnace conditions and how to apply these results to the understanding of industrial combustor environments.

The combustion of the biomass samples appears to occur in three phases, namely:

- the combustion phase during which the volatile matter combusts and primarily $\mathrm{CO}_{2}, \mathrm{CO}$, and $\mathrm{H}_{2} \mathrm{O}$ are produced while $\mathrm{O}_{2}$ is consumed;

- the char-burning phase during which much of the alkali is released;

- and the ash "cooking" stage where very little is observed except for the liberation of a small amount of alkali. Most of the information concerning alkali release and speciation is contained in the char burning phase. 

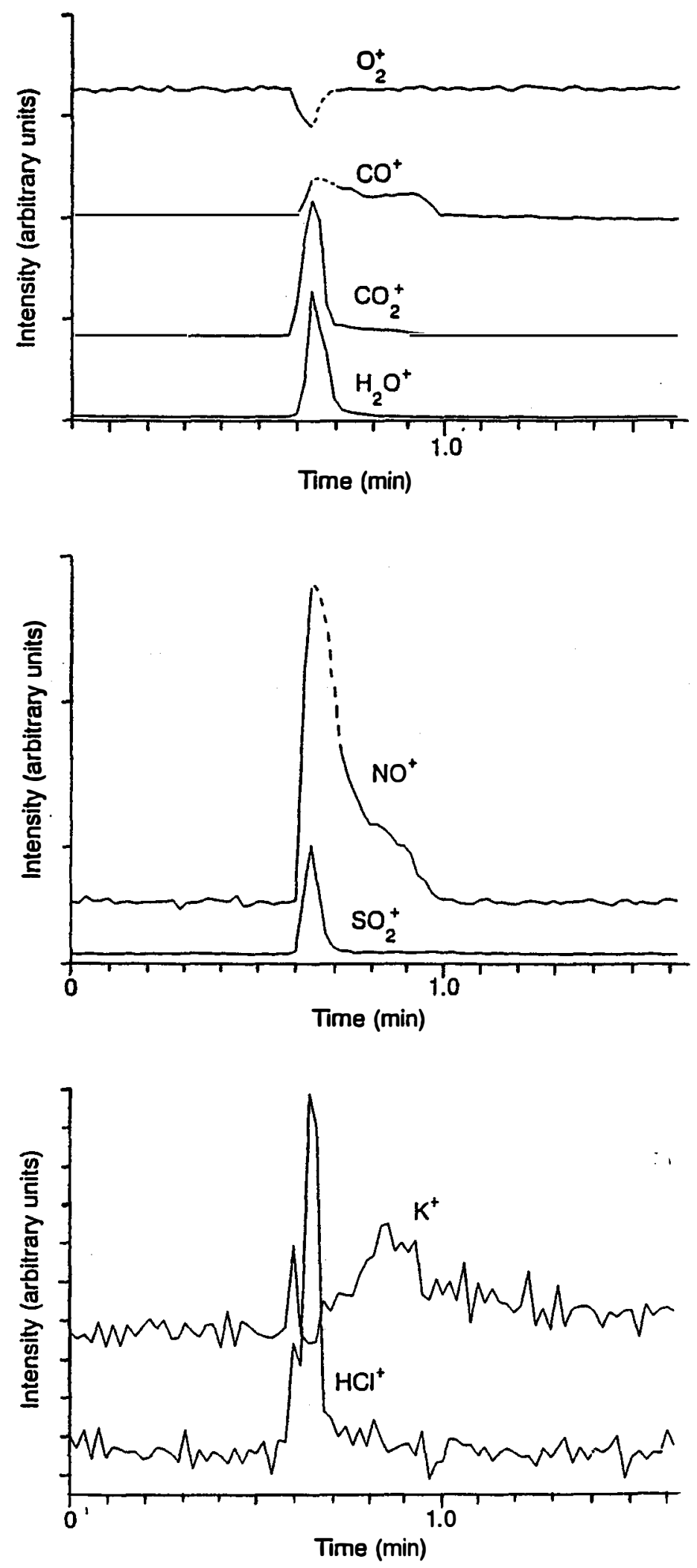

Figure 39. Evolution profiles of species giving the ions indicated. Relative heights have absolutely no significance. Only the time of evolution is to be interpreted. Switchgrass oil sample in flowing $\mathrm{He} / \mathrm{O}_{2}$ at $1100^{\circ} \mathrm{C}$. 

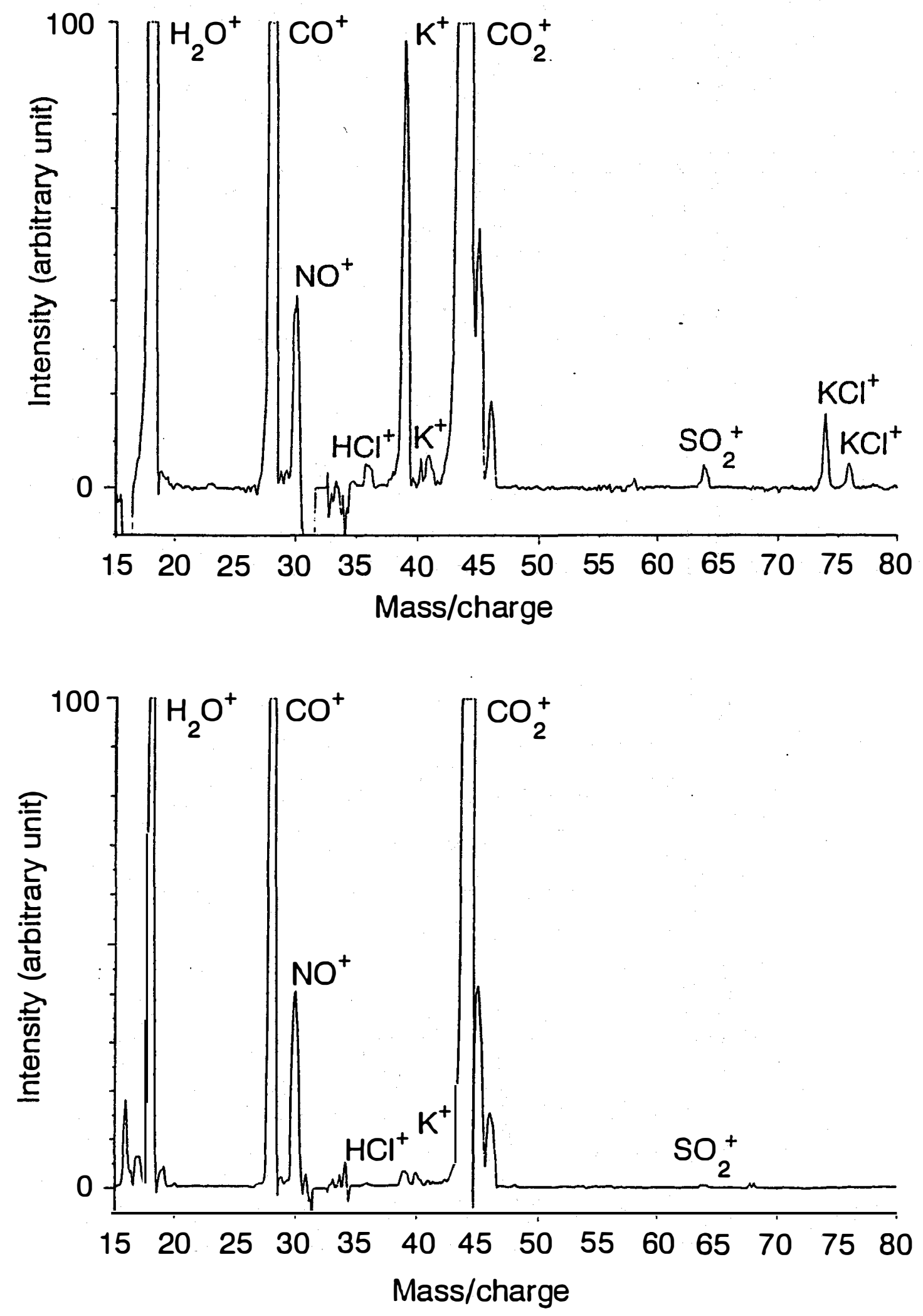

Figure 40. Mass spectra of switchgrass solid (upper spectrum) and switchgrass oil, averaged over the charburning phase of batch combustion. Relative heights of a given species in the two cases are semiquantitatively related to relative partial pressures. 
The results of the screening experiments presented indicate that the amount of alkali released is strongly a function of which biomass feedstock is combusted. Clearly, the alkali release observed during combustion of the woody feedstocks is substantially less than that observed for combustion of the herbaceous feedstocks. This could be expected from the ultimate analyses for each feedstock. However, the identity of the alkali species released could only be confirmed by the mass spectral results presented above. For example, the analyses of the herbaceous feedstocks, switchgrass, rice straw, wheat straw, and corn stover indicate that these biomass feedstocks have a high alkali and chlorine content. The mass spectral data recorded during the char combustion phases of each of these feedstocks reveals that $\mathrm{KCl}$ is the dominant form of the alkali released at $1373 \mathrm{~K}$. On the other hand, for the woody feedstocks, planer shavings of lodgepole pine, eucalyptus, and poplar, identifying the alkali species released during the char phase combustion is more difficult. The primary indication of the release alkali for these feedstocks is observing $\mathrm{K}^{+}$in the char phase mass spectra. Given these results, it is difficult to determine whether the potassium ion results from free potassium being liberated or whether this is a fragment ion from other parent alkali species, such as oxides or hydroxides.

Although the amount of alkali released is highly dependent on the feedstock combusted, there are only minor changes in alkali release observed for the different combustion conditions studied. For example, reducing the oxygen concentration in the combustion atmosphere has little effect on alkali release. The results for the woody feedstocks reveal a change in relative intensity of the $\mathrm{K}^{+}$and $\mathrm{NO}^{+}$in the char phase spectra which suggests that more alkali is being released. These results, however, can also be interpreted in terms of less NO being formed at the lower oxygen concentration. Combustion of the herbaceous feedstocks in a lower oxygen concentration has very little affect on the release of alkali. Adding steam to the combustion environment, however, suggests that potassium release is shifted slightly from $\mathrm{KCl}$ to $\mathrm{KOH}$ during combustion of the herbaceous feedstocks. This is justified by the presence of peaks at 56 and 57 amu in the char phase spectra of switchgrass and corn stover. The equilibrium calculations performed for switchgrass combustion tend to support these observations because the calculated $\mathrm{KOH}$ mass fraction is a factor of two larger in the presence of added steam at $1373 \mathrm{~K}$ than without steam. Potassium chloride is still the major alkali species released. Potassium release during combustion of poplar can also be partially accounted for by releasing of $\mathrm{KOH}$.

Temperature appears to have a significant affect on biomass combustion. The most obvious effect of a reduced furnace temperature on biomass combustion is the lack of $\mathrm{SO}_{2}$ liberated during the char combustion phase. This correlates with an apparent reduction in alkali release during the char combustion of the woody feedstocks. This conclusion is not as obvious for the herbaceous feedstocks. However, the ion-versus-time profiles of alkali species released during switchgrass combustion indicate that alkali release is more prompt at higher temperatures. Several correlations can be made by comparing the equilibrium calculations for switchgrass combustion at $1373 \mathrm{~K}$ and $1073 \mathrm{~K}$. The calculated $\mathrm{SO}_{2}$ mass fraction is three orders of magnitude lower at $1073 \mathrm{~K}$ than at $1373 \mathrm{~K}$ and there is also a lower amount of $\mathrm{K}_{2} \mathrm{SO}_{4}$ in the gas phase. Conversely, the calculations indicate more $\mathrm{K}_{2} \mathrm{SO}_{4}$ in the condensed phase at lower temperatures. These calculations, in conjunction with the experimental results, suggest a mechanism for alkali release involving $\mathrm{K}_{2} \mathrm{SO}_{4}$. This is not entirely surprising because potassium sulfate has been shown to be an important species for alkali release in coal combustion systems (Hastie, Plante and Bonnell 1984 and Sheth, Li and Rasnake 1992). Following the arguments for alkali release presented for coal combustion, potassium sulfate is most likely formed by the reaction of char phase potassium with $\mathrm{SO}_{2}$ produced during combustion. At $1373 \mathrm{~K}$, a lot of $\mathrm{K}^{+}$and $\mathrm{SO}_{2}{ }^{+}$are observed in the char phase mass spectra recorded during biomass combustion according to the following decomposition reaction (Hastie, Plante, and Bonnell 1984): 


$$
\mathrm{K}_{2} \mathrm{SO}_{4}(\mathrm{~s}, \mathrm{l})+2 \mathrm{~K}(\mathrm{~g})+\mathrm{SO}_{2}(\mathrm{~g})+\mathrm{O}_{2}(\mathrm{~g})
$$

At $1073 \mathrm{~K}$, much less $\mathrm{K}^{+}$is seen and little $\mathrm{SO}_{2}{ }^{+}$, if any, is observed in the char phase mass spectra. For the herbaceous feedstocks, the primary alkali species released are the alkali chlorides, $\mathrm{KCl}$ and $\mathrm{NaCl}$. However, at $1373 \mathrm{~K}$ some contribution to the $\mathrm{K}^{+}$signal probably comes from decomposing of $\mathrm{K}_{2} \mathrm{SO}_{4}$. In the woody biomass feedstocks, however, the dramatic decrease of the $\mathrm{K}^{+}$signal in the char phase mass spectra at $1073 \mathrm{~K}$ compared to $1373 \mathrm{~K}$ suggest that the primary species controlling alkali release is $\mathrm{K}_{2} \mathrm{SO}_{4}(\mathrm{~s}, 1)$. The role of sodium sulfate is uncertain at this point because there is much less sodium than potassium in the feedstocks. Because $\mathrm{Na}^{+}$is observed in the char phase spectra of the woody feedstocks and no other sodium species were observed, it is possible that a similar mechanism for sodium release is through the sulfate. Therefore, not only is the amount of alkali released significantly different for the woody feedstocks compared to the herbaceous feedstocks, but the primary mechanism of alkali release may be different. For the herbaceous feedstocks, with high alkali and chlorine content, the primary alkali release mechanism is the vaporization of alkali chloride, predominantly $\mathrm{KCl}$. For the woody feedstocks, with a relatively low alkali content and a low chlorine content, the primary alkali release mechanism is through the decomposing gas phase or condensed phase alkali sulfates.

\section{Conclusions and Future Work}

Several preliminary conclusions can be drawn from these feedstock screening studies. First, the amount of ash remaining in the quartz boats after each experimental run, for the seven feedstocks, quantitatively agreed with the proximate analyses of the feedstocks. Second, the char phase mass spectra can, at least qualitatively be accounted for by the alkali and chlorine content measured in the ultimate analyses of the seven biomass feedstocks. Third, the alkali released during the char combustion phase is predominantly in the form of alkali chlorides for the herbaceous feedstocks and is postulated to originate from solid alkali sulfates for the woody feedstocks. Even under excess steam conditions, equilibrium calculations for switchgrass predict $\mathrm{KCl}$ as the major vapor species. Fourth, the amount of alkali released from both solid biomass and pyrolysis oils, under these simulated 1373K combustion conditions, far exceeds the quoted fuel specifications for liquid, fossil turbine fuels, even for the "clean wood" fuels. Finally, it appears that the sampling and mass spectrometric analysis strategy are adequate to systematically and quantitatively explore the behavior of alkali-containing species in combustion environments of practical interest, and for the whole range of existing and candidate biomass-derived fuels.

With the general success of the chosen experimental technique, we are ready to systematically study alkali release and speciation from a number of different feedstocks of relevance to proposed and existing biomass combustors. The elements of the planned study for the near future include:

\section{A. Apparatus}

1. Refining the heated-tube combustion simulator to provide the products of combustion as an initial environment for the introduced particles, particularly steam.

2. Arranging for the continuous feeding of wood to the flow tube

3. Developing and validating pure compound and standard addition techniques for calibrating alkali species and determining reference spectra of alkali vapors. 
4. Constructing and testing an actual flame system into which particles can be introduced.

5. Specifying and ordering auxiliary laser equipment to permit photoionization in the transportable Molecular Beam/Mass Spectrometer (TMBMS). This technique will be important for sensitive detection of alkali species in the presence of organics produced under gasification and pyrolysis conditions. The main laser system has been ordered using FY93 capital equipment funds.

\section{B. Parametric Alkali Release/Feedstock Screening Studies for Combustion}

1. Effect of varying amounts of excess steam

2. Effect of burning particle size

3. Effect of the nature and composition of candidate biomass feedstocks

4. History of alkali vapor species as they leave the burning surface.

The initial suite of feedstocks to be collected and screened will consist of the following:

- Low and high alkali switchgrass

- Sugar cane bagasse of the type to be gasified in Hawaii

- Corn stover

- Planar shavings of lodgepole pine to be used by PGI/WRI

- The feedstock being gasified at Battelle Columbus

- The feedstock to be gasified at the Institute of Gas Technology

- The rice straw being gasified at MTCI

- The samples being tested in the Sandia multifuel combustor (UC Davis rice straw and wheat straw and selections of 10 biofuels listed by Baxter)

- Pyrolysis oils from NREL and other sources

- Pyrolysis char from NREL

Multivariate analysis techniques will be used to correlate alkali speciation and release, with feedstock composition and combustion conditions.

\section{E. Acknowlegements}

The authors are pleased to acknowledge the support of the Solar Thermal and Biomass Power Division of the DOE Office of Energy Efficiency and Renewable Energy. Special thanks go to Richard Bain and Ralph P. Overend for both programmatic and technical support and guidance, and to David Gratson and Matthew Ratcliff for help with the instrumentation. We also thank Larry Baxter at Sandia for supplying feedstocks and analyses for the fuels also tested in the multi-fired combustor.

\section{F. References}

Ahluwalia, P. K. and K. H. Im. (1989) "Assessment of Fouling, Erosion and Corrosion of Coal-Fired Gas Turbines." In Proceedings of the Advanced Research and Technology Development Direct Utilization, Instrumentation and Diagnostics Contractors Review Meeting, Volume I. D. W. Geiling and P. M. Goldberg, eds. DOEMETC-90/6108., (DE90 000424), pp. 325-335.

Bain, R. L. (1991a) SERI Memorandum, April 15, 1991. 
Bain, R. L. (1991b) "Physical Solids Separation, NREL Milestone Completion Report," Oct. 4, 1991.

Baxter, L. L.; R. C. Mitchell; and T. H. Fletcher (1990). "Experimental Determination of Mineral Matter During Coal Revolatilization." SAND 90-8667. Livermore, California: Sandia National Laboratories.

Baxter, L. L. (1993a). "Ash Deposition During Biomass and Coal Combustion: A Mechanistic Approach" Biomass and Bioenergy, 4, pp. 85-102.

Baxter, L. L. (1993b). "Pollutant Emission and Deposit Formation During Combustion of Biomass Fuels," Quarterly Report, May 15-August 15, 1993. Sandia National Laboratory, NREL MPO No. DZ-211272-1.

Benson, S. A.; C. J. Zyarlicke; E. N. Steadman; and D. P. McCollor. (1989). "Fluid Mechanics of Ash Deposition." In proceedings of the Advanced Research and Development Direct Utilization, Instrumentation and Diagnostics Contractors Review Meeting, Volume I. D. W. Geiling, Goldberg, P. M., eds. DOE METC-89/6108-1, (DE90 000424).

Biomass (1992). "Biomass Combustion Conference," January 28-30, Reno, Nevada, Electric Power Research Institute, Palo Alto, CA.

Biomass and Bioenergy (1993). "Special Issue on Biomass in Combustion: The Challenge of Biomass." 4, pp. 147 .

Boni, A. A. (1989). "Transformation of Inorganic Coal Constituents in Combustion Systems," in Proceedings of the Advanced Research and Technology Development Direct Utilization, Instrumentation and Diagnostics Contractors Review Meeting. Volume I October, eds. D. W. Gerling and P. M. Goldberg Eds. DOE-METC 89/6108, (DE90 000424) pp. 1875.

Bonnell, D. W. and J. W. Hastie (1979). "Transpiration Mass Spectrometry of High Temperature Vapors." In Characterization of High Temperature Vapors and Gases. J. W. Hastie, ed., Washington, DC. p. 357.

Bossart, S. J.; D. C. Cicero; C. M. Zeh; and R. C. Bedick (1990). "Gas Stream Cleanup. Technology Status Report." Morgantown Energy Technology Center. DOEMETC-91-0273. (DE91 002037). pp. 1-63.

Brittain, R. D.; R. H. Lamoreaux; K. H. Lau; and M. E. Gusman (1989). "Vaporization of Trace Inorganic Species From Coal Under Gasification and Combustion Conditions." Final Report for DOE Contract DE-AC21-86MC23261.

Bryers, R. W., ed. (1991). Incinerating Municipal and Industrial Wastes - Fireside Problems and Prospects for Improvements. Hemisphere Publishing Corporation, New York, NY.

Casleton, K. H.; J. P. Kanosky; and W. J. Gase (1987). "Laser-Induced Fluorescense Detection of Mineral Vaporization Species," p. 278. In Proceedings of the Instrumentation, Components and Materials Contractors Meeting. J. M. Hobday, ed. Morgantown Energy Technology Cneter, Morgantown, WV. DOE/METC-86/6069, (DE86 006596).

Coe, D. R. (1992). "Agricultural Fuel Fouling of Fluid Bed Combustors \& Boilers: Cause and Prevention" presented at the Biomass Combustion Conference. Reno, NV. Electric Power Research Institute. 
Corey, R. C.; B. J. Cross; and W. I. Reid (1954). Trans. Amer. Sci. Mech. Eng., 67 p. 289.

CRS Sirrine, Inc. (1990). "Development of Standardized Air-Blown Coal Gasifier/Gas Turbine Concepts for Future Electric Power Systems. Vol. III. Appendix B: NOx and Alkali Vapor Control Strategies, Final Report." DOE/MC/26291-3029 - Vol. 3 (DE92 001126). Prepared by PSI Technology Company, Andover, MA.

Czernik, S. (1993). NREL internal communication.

Czernik, S. (1992). NREL internal communication.

DeGroot, W. F. and F. Shafizadeh (1984). Journal of Analytical and Applied Pyrolysis 6 , pp. 217-232.

DeGroot, W. F. and G. S. Petch. (1986). AIChE Forest Products Division, 1, pp. 144-149.

Evans, R. J. and T. A. Milne (1987b). "Molecular Characterization of the Pyrolysis of Biomass: II. Applications," Energy and Fuels 1, pp. 311-319.

Evans, R. J. and T. A. Milne (1987a). "Molecular Characterization of the Pyrolysis of Biomass: I. Fundamentals," Energy and Fuels 1, pp. 123-127.

Flagan, R. C. (1978). "Submicron Particles from Coal Combustion." 17th Symposium (International) on Combustion. Leeds, England. The Combustion Institute, Pittsburgh, Pennsylvania, p. 97.

Gallagher, N. B.; L. J. Bool; J. O. L. Wendt; and T. W. Peterson (1990) "Alkali Metal Partitioning in Ash from Pulverized Coal Combustion. Combust. Sci. and Tech., 74, pp. 211-221.

Gray, R. L. and R. A. Parham (1982). Chemtech, 12 pp. 232-241.

Greene, F. T. and J. E. O'Donnell (1987). "Investigation of Mechanisms of Ash Deposit Formation From Low-Rank Coal Combustion," Final Report DOE/FC/10287-2416.

Greene, F. T.; D. Robaugh; and J. E. O’Donnell (1988). "Provide Alkali Species Profiles Using a WellCharacterized Coal Reactor," Final Report, DOE/MC/21091-2727.

H. X. Qiu and G. N. Richards (1989). "Attempted Removal of Metal Ions and Subsequent Vacuum Pyrolysis of Barks from Five Species of Softwoods." Journal of Wood Chemistry and Technology, $\underline{9}$ (2), pp. 251-263.

Haas, W. J.; Jr., and D. E. Eckels (1990). "Fiber Optic Alkali Metal Sampling." In Proceedings of the Seventh Annual Coal-Fired Heat Engines and Gas Stream Cleanup Systems Contractors Review Meeting. H. A. Webb; N. F. Rebos; V. P. Fothari; and R. C. Bedick, Eds. March, Morgantown, West Virginia. DOE METC - 90-6110, (DE90 000480), p. 391-402

Hamrick, J. T. (1991). "Development of Biomass as an Alternative Fuel for Gas Turbines." DOE Subcontractor Report PNL-7673.

Hanson, J. L. (1992). "Fluidized Bed Combustion of Biomass" presented at the Biomass Combustion Conference," Reno, NV. 
Hardesty, D. R. and J. H. Pohl (1979). "The Combustion of Pulverized Coals - An Assessment of Research Needs." Sandia Laboratories, Livermore, California.

Hasselriis, F. (1991). "Pilot and Full Scale Tests of Tube Deposits Formation During Combustion of Municipal Refuse." In Incinerating Municipal and Industrial Wastes - Fireside Problems and Prospects for Improvement. Hemisphere Publishing Corporation, New York, NY, p. 343.

Hastie, J. W.; E. R. Plante; and D. W. Bonnell (1981). "Alkali Vapor Transport in Coal Conversion and Combustion Systems." NBSIR 81-2279. PB81-221319. NTIS.

Hastie, J. W.; K. F. Zmbov; and D. W. Bonnell (1984). "Transpiration Mass Spectrometric Analysis of Liquid $\mathrm{KCl}$ and $\mathrm{KOH}$ Vaporization," High Temperature Science 17, pp. 333-364.

Hastie, J. W.; E. R. Plante; and D. W. Bonnell (1982). "Alkali Vapor Transport in Coal Conversion and Combustion Systems," in Metal Bonding and Interaction in High Temperature Systems. Gole and Stwalley, eds. ACS Symposium Series \#179. Chapter 34.

Haynes, B. S.; M. Neville; R. J. Quann; and A. F. Sarofim (1982). Factors Governing the Surface Enrichment of Fly Ash in Volatile Trace Species." Journal of Colloid and Interface Science, 87 , p. 266.

Helble, J. J., and A. F. Sarofim (1987). "Factors Determining the Primary Particle Size of FlameGenerated Inorganic Aerosols." Journal of Colloid and Interface Science, $\underline{128}$, p. 348.

Hensel, J. P.; D. R. Goff; R. G. Logan; R. Pineault; R. R. Romanosky, Jr.; and J. K. Wachter (1987). "On-Line, Real-Time Alkali Monitor For Process Stream Analysis." Rev. Sci. Instr., 58, p. 1647.

Hildenbrand, D. L. and K. H. Lau (1993). "Thermodynamic Predictions of Speciation of Alkalis in Biomass Gasification and Combustion," SRI International, Inc. Final Report for NREL Subcontract XD-2-11223-1, Menlo Park, CA.

Hillis, W. E. and D. de Silva (1979). Holzforschung, 33 p. 4753.

Hodges, N. J. and D. G. Richards (1989). "The Fate of Chlorine, Sulphur, Sodium, Potassium, Calcium, and Magnesium During the Fluidized Bed Combustion of Coal." Fuel, 68, p. 440.

Hollenbacher, R. (1992). "Biomass Combustion Technologies in the United States" presented at the Biomass Combustion Conference. Reno, NV. Electric Power Research Institute.

Howard, E. T. (1971) Wood Science, January. pp. 134-149.

Hshieh, F. Y. and G. N. Richards (1989). Combust. and Flame, 76, 1989, pp. 37-47.

Huffman, G. P.; F. E. Huggins; and N. Shah (1989). "Behavior of Basic Elements During Coal Combustion." Division of Fuel Chemistry Reprints, 197th ACS National Meeting, Dallas, TX. $\underline{34}$, p. 367.

Jamhankar, S. S. and C. Y. Wen (1981). "Review of In-Bed Hydrocarbon, Alkali and Trace Metals Control in Coal." West Virginia University, Morgantown, West Virginia. (DE83 006376). 
Kalmanovitch, D. P.; C. J. Zyarlicke; E. N. Steadman; and S. A. Benson (1989). "Deposition of Beulah Ash in a Drop-Tube Furnace Under Slagging Conditions." Div. of Fuel Chem. Reprints. 34 , (2) Dallas, ACS.

Kimura, S. G.; C. L. Spiro; C. C. Chen (1987). Journal of Engineering for Gas Turbines and Power, 109 , pp. 319-324.

Krause, H. H. (1991). "Corrosion by Chlorine in Waste-Fueled Boilers." pp. 145-159 in Incinerating Municipal and Industrial Waste, Fireside Problems, and Prospects for Improvement. R. W. Bryers, Ed. Hemisphere Publishing Corporation, New York, NY.

Krishnan, G., B. J. Wood; R. H. Lamoreaux; R. M. Platz; G. P. Smith (1991). "Determination of the Fate of Alkali Species in Advanced Coal Conversion Systems," Final Report for DOE contract DE-AC21-87MC24012.

Larson, E. D., and R. H. Williams (1990). "Biomass-Gasifier, Steam-Injected Turbine Cogeneration," J. Eng. Gas Turbine and Power, 112, p. 157.

Larson, E. D., and R. H. Williams (1992). "Advanced Gasification Based Biomass Power Generation". Chapter 17 in Renewable Energy Sources for Fuels and Electricity. T. B. Johanson; H. Kelly; A. K. N. Reddy and R. H. Williams, eds., Island Press, Washington, D.C.

Latham, E.; D. B. Meadowcroft; and L. Pinder (1991). The Effects of Coal Chlorine on Fireside Corrosion." Incinerating Municipal and Industrial Waste, Fireside Problems, and Prospects for Improvement. R. W. Bryers, Ed. Hemisphere Publishing Corporation, New York, NY. pp. 97-117.

Lee, S. H. D. and E. L. Carls. "Measurement of Sodium and Potassium Vapors in Pressurized FluidizedBed Combustion of Beulah Lignite." J. Inst. Energy, 53, pp. 203-210.

Lee, S. H. D. and W. M. Swift (1991). "Alkali Sorber (RABSAM)." In: Proceedings of the Eleventh Annual Gasification and Gas Stream Cleanup Systems Contractors Review Meeting, METC, DOEMETC-91-6123. Vol. 2. (DE92 001102), pp. 472-480.

Lee, S. H. D. and E. L. Carls (1990). "Measurement of Alkali Vapor Concentration in PFBC Flue Gas," Proceedings of the 1989 International Conference on FBC-FBC Technology of Today, held April 30May 3, San Francisco, California, 1989, pp. 977-986.

Lee, S. H. D. and E. L. Carls (1988). "Measurement of Alkali Vapors and Their Removal from a Pressurized Fluidized-Bed Combustor Process Stream," Annual Report for October 1986-September 1987, ANL/FE-88-4-.

Lee, S. H. D.; R. F. Henry; W. I. Wilson; K. M. Myles; W. J. Haas, Jr.; and D. E. Eckels (1985). Proceedings of the Fifth Annual Contractors Meeting on Contaminant Control in Coal-Derived Gas Streams, DOE/METC-85/6025, pp. 513-528.

Magasiner, N, J. W. de Kock (1987). Energy World, August/September, pp. 4-12.

Marschner, H. (1986). Mineral Nutrition of Higher Plants. Academic Press, New York.

McCallum, C. (1992). "Boiler Design Considerations with Respect to Biomass Ash Deposition" presentedat the Biomass Combustion Conference. Reno, Nevada. Electric Power Research Institute. 
McNallan, M.; S. Danyluk; and J. E. Indacochea (1991). "High Temperature Corrosion During Use of Chlorine Containing Coal." DOE/PC91334-T6, (CE92 007886).

Meijer, R.; B. van der Linden; F. Kapteijn; and J. A. Moulijn (1991). "The interaction of $\mathrm{H}_{2} \mathrm{O}, \mathrm{CO}_{2}, \mathrm{H}_{2}$ and CO with the alkali-carbonate/carbon system: a thermogravimetric study" Fuel, $\underline{70}$, pp. 205-214.

Mia, A. J. (1969). Wood Science, 2 , pp. 120-124.

Miles, T. R. (1992). "Operating Experience with Ash Deposition in Biomass Combustion Systems," presented at the Biomass Combustion Conference. Reno, Nevada. Electric Power Research Institute.

Miles, T. R. (1993). "Alkali Deposits," Periodic Reports of the Alkali Deposits Investigation. Thomas R. Miles, Consulting Design Engineers, Portland, Oregon.

Milne, T. A. and H. M. Klein (1960). "Mass Spectrometric Study of Heats of Formation of Alkali Chlorides," J. Chem. Phys. 33, pp. 1628-1637.

Misra, M. K.; D. J. Aerts; C. A. Palmer; and K. W. Ragland (1992). "Ash Composition in a Wood Fired Gas Turbine," to be published. University of Wisconsin, Madison, Wisconsin.

Misra, M. K.; K. W. Ragland and A. J. Baker (1993). "Wood Ash Composition as a Function of Furnace Temperature," Biomass and Bioenergy, 4, pp. 103-116.

Mojtahedi, W., E. Kurkela, M. Nieminen (1990). Journal of the Institute of Energy, pp. 95-100.

Moore, W. E. (1986). Overview of the Department of Energy's Fossil Energy Gas Stream Contaminant Control Program. Proceedings of the Fifth Annual Contractors Meeting on Contaminant Control in Coal-Derived Gas Streams. D. C. Cicero and K. E. Markel, eds. DOE/METC-85/6025, (DE85013703).

Nelson, E. T. (1987). "Assessment of Instrumentation Needs for Advanced Coal Conversion Power Plants." In Gas Stream Cleanup Papers from DOE/METC - Sponsored Contractors Review Meetings in 1987. K. E. Mashel, Jr., METC, ed. DOE/METC-87/6082, (DE87 006516), p. 313-326.

NREL, 1992. Biomass Combustion Conference Proceedings, January 28-30, Reno, Nevada. Available from the National Renewable Energy Laboratory, Golden, Colorado.

Neville, M.; J. McCarthy; and A. F. Sarofim (1983). "Size Fractionation of Submicron Coal Combustion Aerosol for Chemical Analysis." Atmos. Environ., 17, pp. 2599.

Neville, M.; R. J. Quann; B. S. Haynes; and A. F. Sarofim (1981). "Vaporization and Condensation of Mineral Matter During Pulverized Coal Combustion." In Eighteenth Symposium (International) on Combustion. The Combustion Institute, Cambridge, Massachusetts. pp. 1267-1274.

Neville, M. and A. F. Sarofim (1985). "The Fate of Sodium During Pulverized Coal Combustion." Fuel, 64, p. 384.

Oldenborg, R. C. and S. L. Baughcum (1987). "Optical Detection of Alkali Compounds." pp. 34-43 In Proceedings of the Instrumentation, Components and Materials Contractors Meeting. J. M. Hobday, ed., Morgantown, West Virginia. DOE/METC-96-6069, (DE86 006596). 
Oldenborg, R. C. "Optical Detection of Corrosive Compounds." In Proceedings of the Advanced Research and Technology Development Direct Utilization, Instrumentation and Diagnostics Contractors Review Meeting. D. W. Beiling and P. M. Goldberg, Eds. Morgantown, West Virginia. DOEMETC89/6108., Vol. 1, 1989. (DE90 000424), p. 87-99.

Pan, W. P., and G. H. Richards (1989). J. Anal.\& Appl. Pyr., 16, pp. 117-26.

Peterson, J. R., and V. H. Lucke (January, 1979). Combustion, p. 29.

Plumley, A.; G. Kerber, and W. Herrmann (1991). "Gas-Side Corrosion and Fouling in Refuse-Fired Steam Generators Demonstrated by the Wurzburg CHP Station." In Incinerating Municipal and Industrial Waste, Fireside Problems and Prospects for Improvement. R. W. Bryers, Ed.. Hemisphere Publishing Corporation, New York, NY, p. 25.

Quann, R. J., and A. F. Sarofim (1982). "Vaporization of Refractory Oxides During Pulverized Coal Combustion." In Nineteenth Symposium (International) on Combustion. The Combustion Institute. Pittsburgh, PA, p. 1429.

Quann, R. J. and A. F. Sarofim (1986). "A Scanning Electron Microscopy Study of the Transformations of Organically Bound Metals During Lignite Combustion." Fuel, 65, p. 40.

Raask, E. (1985). Mineral Impurities in Coal Combustion. Hemisphere Publishing Company, New York, NY.

Ragland, K. W. and D. J. Aerts (1989). "Development of a Gravel Bed Combustor for Solid Fueled Gas Turbine," Final Report-Phase I, DOE/CE/40735-1.

Reid, W. T. (1981). "Coal Ash - Its Effect on Combustion Systems." In Chemistry of Coal Utilization, Second Supplementary Volume. M. A. Elliott, Ed. John Wiley \& Sons, New York, NY. pp. 13891445.

Reynolds, W. C. (January 1986). "The Element Potential Method For Chemical Equilibrium Analysis: Implementation in the Interactive Program STANJAN," Department of Mechanical Engineering, Stanford University.

Robsen, F. L., and W. A. Blecher (1981). "Assessment of Fuel Gas Cleanup Systems - Final Report." DOEME/12050 - 149. (DE81 025927).

Rothrock, J. W.; R. C. Bourke; T. W. Caraker; and M. C. Williams (March 1990). "Low Cost Fuels for Coal-Fired Turbines." In Proceedings of the Seventh Annual Coal-Fueled Heat Engines and Gas Stream Cleanup Systems Contractors Review Meeting_H. A. Webb; N. F. Rekos; V. P. Kothari; and R. C. Bedick, eds. DOEMETC-90/6110. (DE90 000480), p. 241.

Ruston Gas Turbine, Ltd., (1980). Turbine Data and Information Bulletin TDI028 revision. For Liquid Fuels.

Ruston Gas Turbine, Ltd, (1981). Turbine Data and Information Bulletin TDI028 revision. For natural gas fuel. 
Salour, D.; B. M. Jenkins; M. Vafaei; M. Kayhanian (1992). "Control of in-Bed Agglomeration by Fuel Blending in a Pilot Scale Straw and Wood Fueled AFBC" presented at the Biomass Combustion Conference. Reno, Nevada. Electric Power Research Institute.

Santanam, C. B.; K. Caraker; J. Rothrock; and R. C. Bourke (1990). "Coal-Fueled Turbine Program, An Overview." In Proceedings of the Seventh Annual Coal-Fueled Heat Engines and Gas Stream Cleanup Systems Contractors Review Meeting, Morgantown, West Virginia. DOE/METC-90/6110, (DE90000480), p. 38.

Scandrett, L. A., and R. Clift (December 1984). "The Thermodynamics of Alkali Removal From CoalDerivedGasses." J. Inst. of Energy 391, December, pp. 391-397.

Schultz, S. (1992). "Experience Burning Wood Waste in Fluidized Bed Boilers," presented at the Biomass Combustion Conference. Reno, Nevada. Electric Power Research Institute.

Scotto, M. V.; E. A. Bassham; J. O. L. Wendt; and T. W. Peterson (1988). "Quench-Induced Nucleation of Ash Constituents During Combustion of Pulverized Coal in a Laboratory Furnace." Twenty-Second Symposium (International) on Combustion.. The Combustion Institute, Pittsburgh, Pennsylvania. pp. 239-247.

Scurfield, G.; A. J. Michell; S. R. Silva, Bot. J. Linn. Soc., 66, pp. 277-289.

Sheth, A. C.; J. Li; and D.G. Tasnake (1992). "Interactions Between Potassium and Sulfur Species in a Coal-Fired Magnetohydrodynamics System," J. Air and Waste Manage. Assoc. 42, pp. 1466-1472.

Soltys, M. N. and T. A. Milne (1982). "The SERI High-Pressure, Mass Spectrometric Sampling System." SERI/TR-622-1172, Solar Energy Research Institute, Golden, CO.

Sondreal, E. A.; G. H. Gronhovd; and D. E. Severson (1985). "Alkali Metals in Low-Rank Coals: A Critical Review and Analysis of Research Data on Their Occurrence and Effect in Combustion and Gasification Systems." Coal Energy Technology Consultants, Inc., Grand Forks, North Dakota.

Spacil, H. S.; and K. L. Luthra (September 1982). "Volatilization/Condensation of Alkali Salts in a Pressurized Fluidized Bed Coal Combuster/Gas Turbine Combined Cycle. J. Electrochem. Soc., pp. 2119-2126.

Srinivasachar, S. (1992). Private communication.

Srinivasachar, S.; J. J. Helble; D. O. Ham; and G. Domazetisg. (1989). "A Kinetic Description of Alkali Transformations in Coal Combustion Systems." In Reprints of Papers Presented at the 197th ACS National Meeting, Dallas, Texas, $\underline{34}$, April, p. 391.

Stearns, C. A.; R. A. Miller; F. J. Kohl; and G. C. Fryburg (1988). J. Electrochem. Soc. 124, pp. 1145-1146.

Stearns, C. A.; F. J. Kohl; G. C. Fryburg, and R. A. Miller (1979). NBS Special Pub. 561, Proceedings of the 10th Materials Research Symposium on Characterization of High Temperature Vapors and Gases, pp. 303-355.

Stewart, G. W., and A. Chakrabarti (1982). "Alkali-metal release during the pyrolysis of sodium and potassium benzoates" in High Temperatures-High Pressures, 14 (6), pp.661-608. 
Stringer, J. (1987). Materials Science and Technology $\underline{3}$, pp. 482-493.

Sutcliffe, J. F., and D. A. Baker (1974). "Plants and Mineral Salts," Edward Amold, Ltd., London, England.

Swanson, M. L.; S. A. Benson; and D. P. McCollar (1990). "Mineral Matter Transformation Under Turbine Operating Conditions in a Pressurized Drop-Tube Furnace." In Proceedings of the Seventh Annual Coal-Fueled Heat Engines and Gas Stream Cleanup Systems Contractors Review Meeting. H. A. Webb; N. F. Rekos; V. P. Kothari; R. C. Bedick, eds. DOE/METC-90-6110, (DE90 000480), p. 413.

Todd, D. M. (1991). "G. E. Power Generation: Clean Coal Technologies for Gas Turbines," 1991. Liquid fuel specification.

Van Krevelen, D. W. (1961). Coal, Typology, Chemistry, Physics, Constitution. Elsevier Publishing Company, New York.

Van Zeggemon, F. and S. H. Storey (1970). The Computation of Chemical Equilibria, Cambridge, England. Chapter 2.

Wattendorff, J. Z. (1969). Pflanzenphysiol., 60, pp. 307-347.

Weast, R. C., Ed. (1985). "66 ${ }^{\text {th }}$ Edition of the CRC Handbook of Chemistry and Physics,"' CRC Press, Inc., Boca Raton, FL.

Wen, C. S.; L. H. Cowell; F. J. Smit; J. D. Boyd; and R. T. LeCren (1992). "Coal Alkali Retention in a Slagging Combustor." Fuel $\underline{71}$ p. 219.

Wendt, J. O. L. and T. W. Peterson (1986). "Fixation of Alkali and Trace Metals in High Temperature Co-Current Entrained Flow Gasifiers and Combustors." Proceedings of the Fifth Annual Contractors Meeting on Contaminant Control in Coal-Derived Gas Streams. D. C. Cicero and K. E. Markel, eds. DOE/METC-85-6025 (DE85 013703).

Wenglarz, R. A., and R. G. Fox (1990). Journal of Engineering for Gas Turbines and Power 112 , pp. 9-13.

Wibberley, L. J. and T. F. Wall (1986). "An Investigation of Factors Affecting the Physical Characteristics of Fly Ash Formed in a Laboratory Scale Combustor." Combust. Science and Tech., 48, pp. 177-190.

Wibberley, L. J. and T. F. Wall (1982). "Alkali-Ash Reactions and Deposit Formation In Pulverized-CoalFired Boilers: Experimental Aspects of Sodium Silicate Formation and the Formation of Deposits." Fuel, $\underline{\text { 61, p. } 73 .}$

Williams, M. C. and R. C. Bedick (eds.) (October 1988). "Gas Stream Cleanup - Technology Status Report." DOE/METC-89-0263 (DE89 000925). p. 41.

Wornat (1993). "Combustion Study of Pyrolysis Oils and Chars." Progress Report, August 15-Nov. 15, 1993. Sandia National Laboratories, Livermore, California.

Zimm, B. H., and J. E. Mayer (1944). "Vapor Pressures, Heats of Vaporization, and Entropies of Some Alkali Halides." The J. of Chem. Phys. 12, pp. 362-369. 


\section{Appendix A. Compositional Analyses of The Seven Biomass Feedstocks}

\begin{tabular}{|c|c|c|c|c|c|c|c|}
\hline & $\begin{array}{l}\text { Planer } \\
\text { Shavings }\end{array}$ & Eucalyptus & Poplar & Switchgrass & Rice Straw & Wheat Straw & Corn Stover \\
\hline $\begin{array}{l}\text { Proximate } \\
\text { (Weight \% as rec'd) }\end{array}$ & & & & & .. & & \\
\hline Ash & & 0.48 & 1.16 & 4.22 & 17.30 & 6.55 & 4.75 \\
\hline Volatile & & 78.52 & 80.99 & 72.73 & & & 75.96 \\
\hline Carbon & & 11.66 & 13.05 & 14.89 & & & 13.23 \\
\hline $\begin{array}{l}\text { Ultimate } \\
\text { (Weight \% as rec'd) }\end{array}$ & & & & & - & & \\
\hline Moisture & 34.50 & 9.34 & 4.80 & 8.16 & 7.35 & 6.58 & 6.06 \\
\hline C & 34.50 & 44.89 & 47.05 & 43.04 & 35.42 & 41.96 & 43.98 \\
\hline H & 3.76 & 5.21 & 5.71 & 5.37 & 4.82 & 5.09 & 5.39 \\
\hline $0^{\circ}$ & 26.65 & 39.92 & 41.01 & 38.58 & 34.14 & 39.28 & 39.10 \\
\hline $\begin{array}{l}\text { Ash Composition } \\
\text { (Weight \% as rec'd) }\end{array}$ & & & & & & & . \\
\hline Si & 0.024 & 0.04 & 0.05 & 0.94 & 6.03 & 1.69 & 1.20 \\
\hline $\mathbf{F e}$ & 0.014 & $\cdots$ & $\cdots$ & $\cdots$ & 0.103 & 0.033 & $\cdots$ \\
\hline Al & 0.021 & 0.02 & 0.02 & 0.03 & 0.095 & 0.065 & 0.05 \\
\hline $\mathrm{Na}$ & 0.005 & 0.020 & 0.001 & 0.007 & 0.123 & 0.083 & 0.006 \\
\hline K & 0.057 & 0.038 & 0.311 & 0.989 & 1.77 & 1.39 & 1.08 \\
\hline $\mathrm{Ca}$ & 0.116 & 0.091 & 0.392 & 0.223 & 0.372 & 0.287 & 0.294 \\
\hline Mg & 0.013 & 0.021 & 0.081 & 0.117 & 0.182 & 0.042 & 0.175 \\
\hline $\mathbf{P}$ & $\ldots$ & 0.061 & 0.075 & 0.284 & 0.107 & 0.036 & 0.180 \\
\hline
\end{tabular}

* Oxygen by difference

** Not usually reported as part of the ultimate analysis 
TP-5597

A-2 


\begin{tabular}{|c|c|c|c|}
\hline $\begin{array}{l}\text { Document Control } \\
\text { Page }\end{array}$ & $\begin{array}{l}\text { 1. NREL Report No. } \\
\text { NREL/TP-430-5597 }\end{array}$ & $\begin{array}{l}\text { 2. NTIS Accession No. } \\
\text { DE94000262 }\end{array}$ & 3. Recipient's Accession No. \\
\hline \multicolumn{3}{|c|}{$\begin{array}{l}\text { 4. Title and Subtitle } \\
\text { Direct Observation of Alkali Species in Biomass Combustion and Gasification }\end{array}$} & 6. \\
\hline \multicolumn{3}{|c|}{ 9. Performing Organization Name and Address } & $\begin{array}{l}\text { 10. Project/Task/Work Unit No. } \\
\text { BP31.34392 }\end{array}$ \\
\hline \multirow{2}{*}{\multicolumn{2}{|c|}{$\begin{array}{l}\text { 12. Sponsoring Organization Name and Address } \\
\text { National Renewable Energy Laboratory } \\
1617 \text { Cole Blvd. } \\
\text { Golden, CO } 80401-3393\end{array}$}} & & $\begin{array}{l}\text { 13. Type of Report \& Period Covered } \\
\text { Technical Report }\end{array}$ \\
\hline & & & 14. \\
\hline \multicolumn{4}{|c|}{$\begin{array}{l}\text { 16. Supplementary Note } \\
\text { Dr. Thomas Milne, (303) 231-7000, x1440 }\end{array}$} \\
\hline \multicolumn{4}{|c|}{$\begin{array}{l}\text { 17. Document Analysis } \\
\text { a. Descriptors } \\
\text { biomass fuels, biomass combustion, power generation, gas turbines } \\
\text { b. Identifiers/Open-Ended Terms }\end{array}$} \\
\hline \multirow{2}{*}{\multicolumn{2}{|c|}{$\begin{array}{l}\text { 18. Availability Statement } \\
\text { National Technical Information Service } \\
\text { U.S. Department of Commerce } \\
\text { 5285 Port Royal Road } \\
\text { Springfield, VA } 22161\end{array}$}} & & $\begin{array}{l}\text { 19. No. of Pages } \\
90\end{array}$ \\
\hline & & & $\begin{array}{l}\text { 20. Price } \\
\text { A05 }\end{array}$ \\
\hline
\end{tabular}

Form No. 0069E (6-30-87) 